FIRST ANIVUAL REPORT

STATE DAIRY COMMISSIONER

MIISSOURI

1905 


$$
\text { \% }
$$






\section{FIRST ANNUAL REPORT}

OF THE

\section{STATE DAIRY COMMISSIONER}

TO THE

\section{Governor of the State of Missouri}

R. M. WASHBURN,

State Dairy Commissioner.

Printed by Order of the General Assembly.

THE HUGH STEPHENS PRINTING COMPANY, JEFEERSON CITY, MO. 


$$
S \mathrm{~F}^{2^{5}} \mathrm{M}^{\mathrm{S}}
$$

By transfor

.OCT 21906 


\section{TABLE OF CONTENTS.}

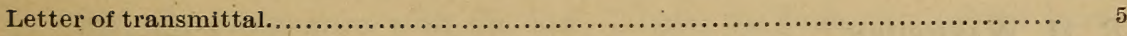

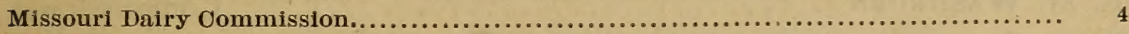

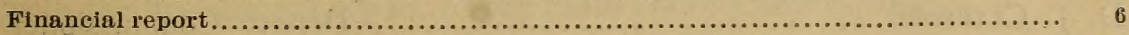

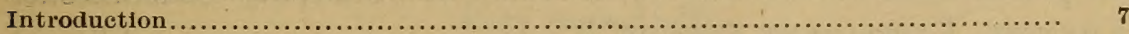

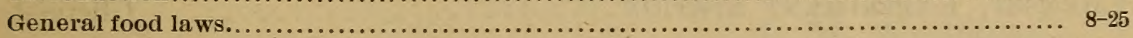

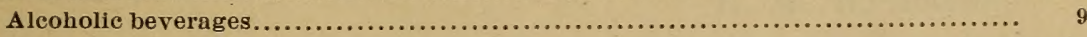

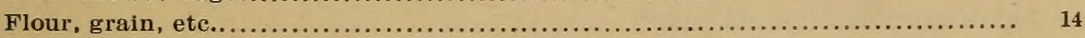

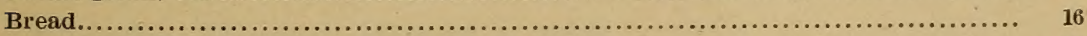

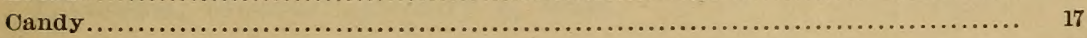

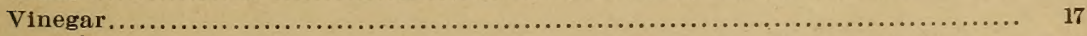

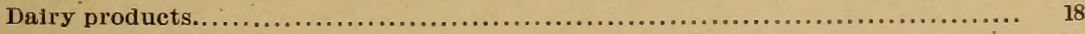

Dairy Commission established............................................. 23

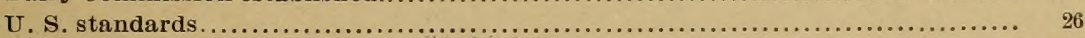

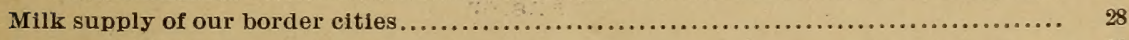

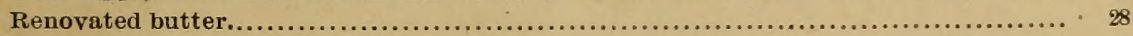

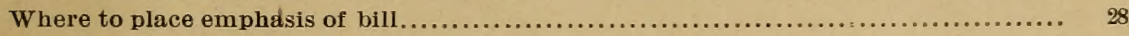

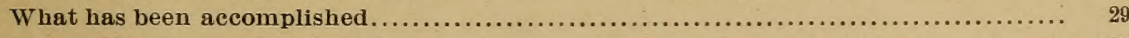

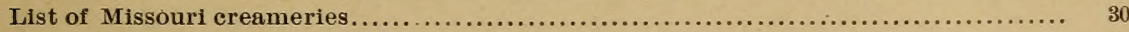

The co-operative creamery in Missouri........................................ 31

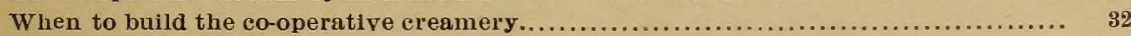

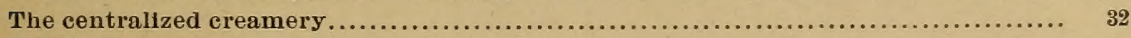

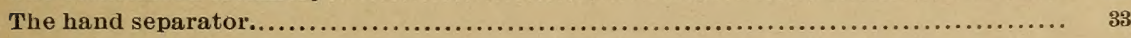

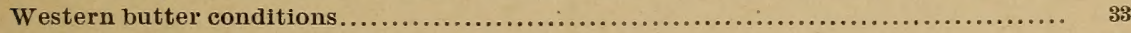

The farmers' part in making Missouri a dairy state............................ 36

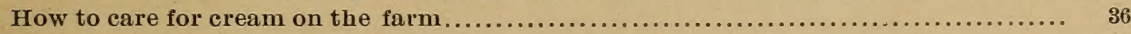

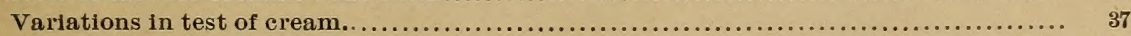

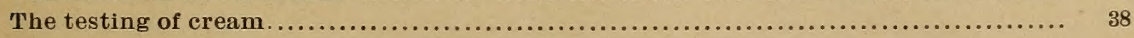

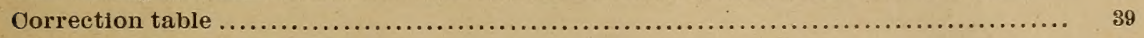

More butter than butter fat. . . . . . . . . .

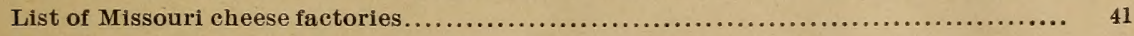

The co-operative cheese factory in Missouri.................................... 41

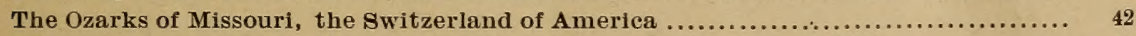

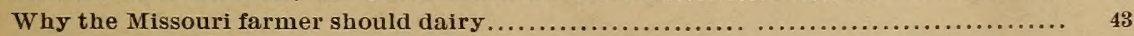

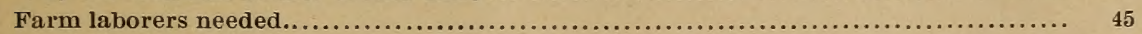

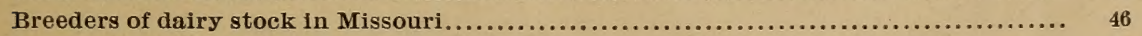

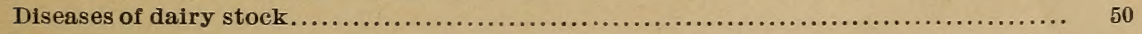

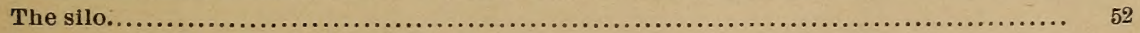

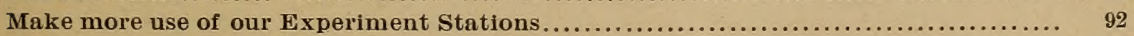




\section{MISSOURI DAIRY COMMISSION.}

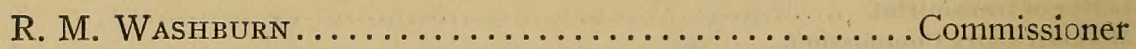

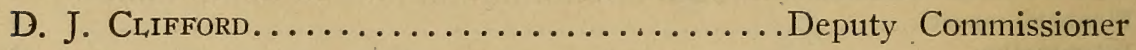

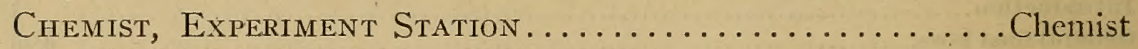




\section{LETTER OF TRANSMITTAL.}

To His Excellency, Joseph W. Folk, Governor of Missouri :

Sir-In compliance with the law, I have the honor to submit herewith the first annual report of the State Dairy Commissioner.

Very respectfully,

R. M. WASHBURN,

State Dairy Commissioner.

Columbia, Missouri, January I, 1906. 


\section{FINANCIAL REPORT.}

(From July I7, 1905, to January I, I906.)

Salary of Commissioner................... \$908 ${ }_{56} 6$

Salary of Deputy Commissioner............ 545 I6

$\$ 1,45372$

Traveling expenses of Commissioner.......... \$434 27

Traveling expenses of Deputy Commissioner....... 67382

I, 10809

Printing, letter heads, blank forms, envelopes, etc... \$175 I9

'I75 I9

Total .

$\$ 2,73700$ 


\section{INTRODUCTION.}

This first report of the first Dairy Commissioner in this State will of necessity be made up largely of records of present conditions in the clairy industry, rather than an account of what has been accomplished by this office.

For a number of years past there has been a feeling abroad in the State that there was need for a State Dairy and Food Commissioner, whose duty it should be to help the consumers to get what they ask for and what they pay for in the way of foods of all kinds, and to promote and guide the dairy interests of the State. Several bills have been introduced to this end, but all failed of passage until last winter, when a bill, gotten up. by the clairy supporters, independent of the food element, and fostered by the State Dairy Association, passed and became a law April 8, 1905.

The present incumbent was appointed by Governor Folk to the office of State Dairy Commissioner July i7, and immediately appointed his deputy, D. J. Clifford of St. Joseph, and they both commenced their official duties at once.

R. M. WAShBURN, State Dairy Commissioner.

Columbia, Mo., January I, 1906. 


\section{GENERAL FOOD LAWS.}

2266. Unwholesome mcat, bread, or drink; penalty. Every person who shall knowingly sell the flesh of any animal dying otherwise than $\mathrm{b}$; slaughter, or slaughtered when diseased, or shall sell the flesh as of one animal, knowing it to be that of another species, or shall sell unwholesome bread or drink without making the same fully known to the purchaser, and any butcher or other person who shall sell or offer to sell the meat of any calf which was killed before it had attained to the age of six weeks, shall be deemed guilty of a misdemeanor, and upon conviction thereof, shall be punished by a fine not exceeding one thousand dollars, or by imprisonment in the county jail not exceeding one year.

2267. Cleanliness of food receptacies. It shall be unlawful for any person, firm or corporation to use any barrel, lard tierce, preserve or butter tub, having been once used, for the purpose of packing or storing any article of human food therein, unless such barrel, lard tierce, preserve or butter tub has been thoroughly cleaned or scoured before its subsequent use.

2268. Penalty. Any person violating the provisions of the foregoing section shall be deemed guilty of a misdemeanor, and on conviction thereof shall be fined not less than five dollars nor more than twenty dollars for each offense, and by the using of any single article as before mentioned shall constitute a separate offense.

2269. Adulteration of food and drugs. Every person who shall fraurlulently adulterate, for the purpose of sale, anything intended for food or drink, or any drugs or medicine, shall be deemed guilty of a misdemeanor.

Revised Statutes, I899, Vol. I, p. 627.

2286. Ingredients prohibited. It shall be unlawful for any person or corporation doing business in this State to manufacture, sell or offer to sell, any article, compound or preparation, for the purpose of being used or which is intended to be used in the preparation of food, in which article, compound or preparation there is any arsenic, calomel, bismuth, or ammonia.

2287. Penalty. Any person or corporation violating the provisions 
of section 2286 shall be deemed guilty of a misdemeanor, and shall, upon conviction, be fined not less than one hundred dollars, which shall be paid into and become a part of the road fund of the county in which such fine is collected.

Revised Statutes, I899, Vol. I, p. 63I.

6127. Citics may provide for inspection of animals intended for food. All cities in this State are hereby empowered to provide by ordinance for the inspection, while living, of all animals intended as liuman food within such cities.

Revised Statutes, I899, Vol. 2, p. I437.

\section{ALCOHOLIC BEVERAGES.}

2278. Poisonous ingredients; penalty. Any person who shall adulterate, by the use of strychnine or other poisonous liquids or ingredients, any spirituous, fermented, malt or vinous liquors, or shall sell any such liquors by retail or wholcsale, knowing the same to be adulterated as aforesaid by or with strychnine or other poisonous liquids or ingredients, shall be deemed guilty of a felony, and, upon conviction thereof, be punished by imprisonment in the penitentiary not exceeding five years.

2288. Adulterated hops, malt, or yeast, in beer; penalty. No substitute for hops or the pure extract of hops, or of pure barley malt or wholesome yeast shall be used in the manufacture of ale or beer in this State, and all ale or beer shown to contain any substance used as a substitute for hops, or pure extract of hops, or pure barley malt or wholesome yeast, is hereby declared adulterated. Whoever manufactures for sale any ale or beer adulterated as referred to in this section, or sells or offers to sell any such ale or beer, knowing it to be adulterated as aforesaid, shall be deemed guilty of a misdemeanor, and, upon conviction, shall be punished by a fine of not less than five hundred and not more than five thousand dollars, or by imprisonment in the county jail not less than one month nor more than six months, or by both such fine and imprisonment.

2289. Liquor dealers' oath and bond. It shall not be lawful for any person or persons to sell or offer to sell any spirituous, fermented, malt or alcoholic liquors within this State until he, she or they shall first appear before the county court clerk of the county where such liquors are to be sold or offered for sale, and take and subscribe an oath not to mix or adulterate, with any substance whatever, the liquors offered for sale, and give bond in the sum of five hundred dollars, with good and sufficient surety, for the payment of all costs arising from prosecutions for violations of the provisions of this article in relation to the adulteration and sale of intoxicating liquors. 
2290. Liquor manufacturers' oath. It shall not be lawful for any. person or persons to manufacture or rectify any spirituous, fermented, malt or alcoholic liquors within the limits of this State until he, she or they shall first appear before the county court clerk of the county where such liquors are proposed to be manufactured or rectified, and take and subscribe an oath not to adulterate, or suffer to be adulterated, any liquors manufactured or rectified by themselves or agents.

229I. Liquor dealers affidavit. Before any person or copartnership of persons shall be authorized to sell intoxicating liquors he, she or they shall file with the clerk of the county court, in the county where it is desired to sell the same, an affidavit to the following effect, to wit:

I, A B, do solemnly swear that. I will not mix or adulterate, with any poisonous substance whatever, any distilled or fermented liquors, or any composition of which distilled or fermented liquors form a part, nor will I mix the different kinds of liquors together for the sake of profit, nor dilute the same with water, nor will I permit the same to be done.

2292. Penalty. If any person or persons shall sell any spirituous, fermented, malt or alcoholic liquors in violation of or without complying with the three next preceding sections, he or they shall be deemed guilty of a misdemeanor, and on conviction be punished by a fine of not less than fifty nor more than five hundred dollars.

2293. Druggists, etc., exempt. Nothing herein shall be so construed as to prevent druggists, physicians or persons engaged in the mechanical arts from mixing and adulterating liquors for medicinal or mechanical purposes, to be by them used in their business.

2294. Summons by grand jury. The grand jury may send for persons or papers in cases where they may be of the opinion that any person or persons have been guilty of violating any of the provisions of sections 2278, 2279, 2288, 2289, 2290, 2291, 2292 and 2293.

Revised Statutes, I889, Vol. I, 632 .

7682. (SEC. r.) Appointment of inspector of beer and malt products. There is hereby created the office of beer inspector, which shall be filled by appointment by the Governor, by and with the consent of the Senate, within thirty day's after the taking effect of this act, an inspector of beer and malt products, who shall serve for a term of four years and until his successor is duly appointed and qualified. He shall be an expert beer brewer and a citizen of the United States and of this State for more than two years next prior to his appointment. He shall give a bond in the sum of twenty-five thousand dollars, to be approved by the Governor, for the faithful performance of the duties of his office.

7683. (SEc. 2.) Deputics and clerical help. Said inspector shall, with the approval of the Governor, appoint such deputies as may be re- 
quired to carry out the provisions of this article, not to exceed four in number, and such clerical help as may be necessary. Said deputies shall each receive for their services the sum of fifteen hundred dollars per annum, and said inspector shall receive the sum of three thousand dollars per annum, all salaries and expenses to be paid out of the sums of money now, or that may hereafter be, appropriated for said purpose.

7684. (SEC. 3.) Inspection of beer obligatory. Every person, persons or corporation who shall erect or keep a brewery for the manufacture or brewing of beer or other malt products within this State, for the purpose of offering the same for sale, shall cause the same to be inspected by the said State Inspector.

7685. (SEC. 4.) Use of chemicals, mwholesome yeast, etc., prohibitcd. No person, persons or corporation, engaged in the brewing or mantufacture of beer or other malt liquors, shall use any substance, material or chemical in the manufacture or brewing of beer or other malt liquors, other than pure hops or pure extract of hops, or of pure barley, malt, or wholesome yeast, or rice.

7686. (SEC. 5.) Imported malt liquors to be inspected and affidavit made as to purity; labcls and fecs. Every person, persons or corporation who shall receive for sale or offer for sale any beer or other malt liquors other than those mantufactured in this State shall, upon receipt of same, and before offering for sale, notify the inspector, who shall be furnished with a sworn affidavit, subscribed by an officer authorized to administer oaths, from the manufacturer thereof, or other reputable person having actual knowledge of the composition of said beer or other malt liquors, that no material other than pure hops of the extract of hops, or pure barley, malt or wholesome yeast, or rice, was used in the manufacture of same; upon the receipt of said affidavit, the inspector shall inspect and label the packages containing said beer or malt liquors, for which services he shall receive like fees as those imposed upon the manufacturers of beer and malt liquors in this State.

7687. (SEC. 6.) Records and report of inspector. The inspector appointed under this article shall provide himself with an office and shall record on books kept for that purpose the names and places of business of all persons engaged in the manufacture, brewing and sale of beer and malt liquors. He shall keep a record of all beer and malt liquors manufactured, brewed or sold and the amount produced by each brewery or manufacturer, or sold by dealer. He shall keep a record of all fees collected and all expenditures incurred, and shall make a full and complete report of the same to the Governor upon the first day of each year.

7688. (SEC. 7.) All malt products to be inspected and labeled. It shall be the duty of each inspector to cause to be inspected all beer 
or other malt liquors brewed or manufactured or sold in this State, and if he shall find that such beer or other malt liquor has been made from pure hops or the pure extract of hops, or of pure barley, malt or wholesome yeast, or rice, to place upon the package containing such beer or malt liquor his label, certifying that the same has been inspected and made from wholesome ingredients.

7689. (SEc. 7a.) State Treasurer to furnish labels, etc. It shall be the duty of the State Treasurer upon the taking effect of this article to provide suitable and inimitable State certificates and labels for this inspection, gauging and labeling, having on each proper places for countersigning by the State Treasurer and inspector, and shall safely keep the same together with the plates used in making them, when not in actual use. The State Treasurer shall from time to time, upon demand, deliver the aforesaid labels to the inspector, taking therefor his receipt, and shall charge said inspector with the same; and shall from time to time, as said inspector makes returns of moneys collected in the course of his inspection, credit said inspector's account with such sums, and shall keep a true and correct book account of his dealings with said inspector.

769o. (SEC. 7b.) Fraudulent use of inspector's labels; penalty. It shall be unlawful for any person to attempt to make or make, to attempt to sell or sell, or attempt to use or use any of the certificates or labels or both provided for by this article, or imitations thereof, except such persons as by law are allowed to make, sell and use the same, and any person so offending shall be deemed guilty of a felony and, upon conviction, be punished by imprisonment in the penitentiary for a term not to exceed five years.

769I. (SEc. 8.) Inspector's fees; "package" defined. The inspector shall be entitled to receive for inspecting and gauging one cent for each gallon contained in each package, and two cents for labeling each package. All fees received by the inspector shall be paid into the State treasury. The word package, as used in this article, shall be construed to mean any vessel of any kind other than pint and quart bottles in which any beer or malt liquor may be placed for sale, containing eight gallons or less; when said beer or malt liquors are placed in pint or quart bottles, a package, as used in this article, shall be construed to mean not to exceed forty-eight pint bottles or 24 quart bottles of beer or malt liquors, which, when manufactured and so bottled, must, before sale, be placed in suitable cases containing said number and size of bottles, for inspection and stamping by said State inspector; and when said beer or malt liquors shall be placed in vessels containing more than eight 
gallons, the word package shall be construed to mean each eight gallons or fractional part thereof so contained in said vessel.

7692. (SEC. 9.) Expenses, salaries, etc.; disposal of fines. The expense of said office, including the salaries of the inspector and his deputies, shall be paid monthly out of the amount appropriated by law from the general revenue fund on warrants drawn by the State Auditor on vouchers approved by the inspector, and all fees received by the inspector under the provision of this article shall, on or before the last day of each month, be paid into the State treasury by said inspector, and shall be placed to the credit of the general revenue fund.

7693. (SEC. IO.) Sale of uminspected malt products; penalty. Any person who shall sell any beer or malt liquors within this State which has not been inspected according to the provisions of this article, or contained in packages which shall not have upon them the certificate of the State inspector, or any person shall fail to destroy said certificate or label after the contents of said package are disposed of, shall be deemed guilty of a misdemeanor, and upon conviction thereof, shall be punished by a fine not exceeding five hundred dollars, or by imprisonment in the county jail for a period of not less than six months, and in addition thereto shall have his license or other authority, giving him the right to manufacture or sell said liquors in this State revoked, and shall not again' receive any such license or other authority for a period of two years thereafter.

7694. (SEc. Ir.) Punishment of delinquent inspector. If any inspector shall fail to perform any of the duties imposed upon him by this article, or shall in any manner violate any of the provisions thereof, he shall be deemed guilty of a misdemeanor, and upon conviction thereof, shall be punished by imprisonment in the county jail for not less than thirty days and by a fine not exceeding one thousand dollars, and if any said inspector shall fail to faithfully perform the duties enjoined upon him by this article he may be removed from office by the Governor.

7695. (SEC. I2.) Prosecutions. All prosecutions for fines and penalties under the provisions of this article shall be either by indictment or information in any court of competent jurisdiction; and when collected shall be paid one-fourth to the informer and three-fourths into the fund for the construction of public roads and highways in the county in which said offense may have been committed and prosecution begun.

7696. (SEC. 13.) Inspection of exported malt products. All beer or other malt liquors manufactured in the State and exported outside of the State for sale shall be inspected as other liquors designated in this article, but said inspection shall be free of cost to manufacturer.

7597. (SEc. I3a.) Duplicate bill of lading to be furnished by transportation companies; penalty. Every railroad, express or transporta- 
tion company shall, when requested, furnish to the inspector a duplicate bill of lading or receipt showing the name of the consignor and consignee, date, place received, destination and quantity of beer or malt liquors received by them for shipment to any point within this State. Upon failure to comply with the provisions herein, said railroad, express or transportation company shall forfeit and pay to the State of Missouri the sum of fifty dollars for each and every failure, to be recovered in any court of competent jurisdiction. The inspector herein provided for is hereby authorized and empowered to sue in his own name at the relation and to the use of the State. The penalties collected shall be paid into the State treasury.

(SEC. I4.) Appropriation. There is hereby appropriated out of the State-treasury, chargeable to the general revenue fund, for the years 1899 and 1900, for the pay of the inspector, six thousand dollars; for the pay of four deputies, twelve thousand dollars; for rent, stationery, fuel, printing, and such other things as may be necessary for the transaction of the business of said inspector, the sum of six thousand dollars.

Approved May 4, I899. Laws of I899, pp. 228-23I ; Revised Statutes, 1899, Vol. 2, pp. 1792-I795.

FLOUR, GRAIN, ETC.

8501. Mired grains to be branded. No person shall sell or offer for sale any flour, meal, grits or hominy made from the admixture or adulteration of grains, unless there shall have been first branded upon each of the barrels or packages containing the same kind of grains composing said admixture, the quality and weight thereof, and the name and place of business of the person manufacturing the same: Prosided, alrvay's, That the admixture of the several grades or kinds of wheat shall not be construed to be mixed or adulterated grains.

8502. Defacing of brands. No person shall deface, remove, obliterate or destroy, or cause the same to be clone, any brand or mark placed upon any package or barrel of flour, meal, grits or hominy by the manufacturer thereof, with the intent to replace the brand so erased and removed by another and different brand from that of the manufacturer; and it shall not be lawful for any person to rebrand any such package or barrel so long as the contents thereof remain the same.

8503. Brands to be filcd and acknozuledged. No person shall manufacture any flour, grits, hominy or meal until he shall have filed with the recorder of deeds of the county in which his business is conducted, and acknowledged the same as deeds to lands are required to be acknowledged, a fac simile of each of the brands he intends to use, which shall 
contain the colors to be used in applying the same, the weight and quality of the flour, grits, hominy or meal, and the name of the mantufacturer thereof, or of some person in his employ, and the state or town or place and the mill where manufactured. Should any mantufacturer claim any of his said brands, or any part of the same, as a trade mark, the said recorder shall record his claim, and thereafter it shall not be lawful for any other person to use such brand: Provided, always, That this section shall not be construed to interfere with the rigint to any brand or trade mark copyrighted or patented in pursuance of an act of Congress.

8504. False brands. No person within this State shall use the name of a mill or a brand upon any barrel or package containing flour made from grains or the admixture of grains unless the same shall belong, bona fide, to the person using the same, nor unless the flour upon which the same may be used was manufactured by the owner of such mill or brand.

8505. Record of brands. It shall be the duty of each recorder of deeds within the State to keep a book in his office, in which to record the flour brands provicled for in section 8503 , and a certified copy of any such record by the recorder shall be evidence in all courts of the making and filing and contents thereof.

8506. Penalty. Any person doing any of the acts in this article prohibited, or omitting to do any of the acts herein commanded, shall be guilty of a misdemeanor, and for each and every offense shall be punished by a fine of not less than twenty nor more than two hundred dollars, one-half of which shall be paid to the person who shall be named as prosecuting witness.

Revised Statutes, I899, Vol. 2, p. 1992.

10578. Label showing weight; penalty. A barrel of flour shall consist of 196 pounds net; a sack of flour shall consist of 98 pounds net; a half sack of flour shall consist of 48 pounds net; a quarter sack of flour shall consist of 24 pounds net; no manufacturer or dealer in flour shall sell flour in barrels, sacks, half sacks or quarter sacks containing a less amount of flour than the amounts above specified. Before any barrel, sack, half sack or quarter sack of flour shall be sold, the number of pounds therein contained shall be plainly labeled or stamped thereon. Any person who shall sell any package of flour which shall be stamped or labeled with a greater number of pounds net than such package actually contains, or who shall put up or sell flour in any manner contrary to the provisions of this section, shall be deemed guilty of a misdemeanor, and upon conviction thereof, shall be fined in a sum not less than ten dollars nor more than one hundred dollars.

Revised Statutes, I899, Vol. 2, Ch. I73, Sec. I0578, p. 2448. 
BREAD.

roo89. Santation. All rooms or buildings occupied as buscuit,* bread or cake bakeries shall be drained and plumbed in a manner to conduce to the proper and healthful sanitary condition thereof, and constructed with air-shafts, windows or ventilating pipes, sufficient to insure ventilation. The furniture and utensils in such rooms shall be so arranged that the furniture and floor may at all times be kept in a proper and healthful sanitary condition, and no water-closet, earth-closet, privy or ash pit shall be within or communicate directly with the bake room.

Ioogo. Storage. The manufactured flour or meal products shall be kept in perfectly clean, dry and properly ventilated rooms, so arranged that the floor, shelves and all facilities for storing same can be easily and perfectly cleaned.

roogr. Sleeping apartments to be separate. The sleeping apartments for the persons employed in bakeries or confectionery establishments shall be separate and distinct from the room or rooms used for manufacture or storage of flour or meal products or for the storage of flour, meal or other articles used in the manufacture or preparation of such product.

I0092. Diseased persons not to work in bakeries. No employer shall knowingly require, permit or suffer any person to work in his bakeshop who is affected with consumption of the lungs, or with scrofula or any communicable disease, and every person is hereby required to keep himself in a cleanly condition while engaged in the manufacture or handling of such products.

ro093. Penalty. Any person who violates any of the provisions of this article, or refuses to comply with the requirements thereof, shall be deemed guilty of a misdemeanor, and, on conviction, shall be punished by a fine of not less than ten or more than one hundred dollars.

I0094. Duty of Labor Commissioner. It shall be the duty of Labor Commissioner or his deputy to see that the provisions of this article are carried into effect, and it is hereby made the duty of the prosecuting attorneys of each county or city in this State to lend all possible aid in all prosecutions for violations of any of the provisions of this article.

10095. Article to be posted. A copy of this article shall be kept conspicuously posted in every bake-shop or confectionery establishment in this State.

Revised Statutes, 1899, Vol. 2, Ch. I6I, Art. 4, pp. 2348-2349.

- So In Statutes. 


\section{CANDY.}

2279. Injurious ingredients. No person shall, by himself, his servant or agent, or as the servant or agent of any other person or corporation, manufacture for sale, or knowingly sell or offer to sell, any candy adulterated by the admixture of terra alba, barytes, talc or any other mineral substance, by poisonous colors or flavors, or other ingredients deleterious or detrimental to health.

2280. Penalty. Whoever violates any of the provisions of section 2279 shall be punished by a fine not exceeding one hundred dollars $(\$ 100.00)$, nor less than fifty dollars $(\$ 50.00)$. The candy so adulterated shall be forfeited and destroyed under direction of the court.

228I. State prosecuting attorneys. It is hereby made the duty of the prosecuting attorneys of this State to appear for the people and to attend to the prosecution of all complaints under section 2279 in all the courts in their respective counties.

Revised Statutes, 1899. Vol, I, p. 630.

\section{VINEGAR.}

2282. (I) Imitation or adulterated cider vinegar; penalty. That any person who manufactures for sale, or offers or exposes for sale as cider vinegar, any vinegar not the legitimate product of pure juice, known as apple cider, or vinegar not made exclusively of said apple cider or vinegar into which foreign substances, drugs or acids have been introduced, as may appear on proper tests, shall be deemed guilty of a misdemeanor, and, upon conviction thereof, be punished for every offense by fine of not less than fifty dollars nor more than one hundred dollars and the costs of prosecution, or by imprisonment in the county jail not to exceed ninety days.

2283. (2) Artificial coloring or flavoring; false branding. All vinegar sold or offered for sale, exchange or delivery shall be without artificial coloring or flavoring; and no person, by himself or by his agent or employe, shall sell or offer for sale, exchange, deliver, or knowingly have in his custody or possession, with intent to sell or exchange or expose or offer for sale or exchange, any vinegar labeled or branded as cider vinegar, or as apple vinegar, which is not the legitimate product of pure apple juice or that is not made exclusively from apple cider.

2284. (3) Branding; inspection. Every person making or manufacturing apple, cider, or other fruit vinegar, for sale, shall brand on both heads of each cask, barrel, or keg, containing such vinegar, the name and location of the manufacturer or firm, and also the name of 
the fruit out of which the vinegar is made; and where there are inspectors of food products, vinegar shall be one of the articles under supervision of such inspector, with power to inspect and seize any that may be found fraudulent and in violation of sections $2282,2283,2284$ and 2285 .

2285. (4) Branding of "fruit vinegar," penalty. No vinegar shall be branded "fruit vinegar," unless the same shall be made wholly from apples, grapes or other fruits; and any person who shall knowingly brand, label or sell, or offer for sale as such "fruit vinegar," any vinegar not made wholly from apples, grapes or other fruit, or who shall violate any one of the foregoing sections, shall be deemed guilty of a misdemeanor and be punished as provided in section 2282 .

Approved April I, I89I. Revised Statutes, I899, Vol. I, pp. 63063I.

\section{DAIRY PRODUCTS.}

2276. Imitation butter and cheese to be so labeled; penalty. Whoever manufactures out any oleaginous substances, or any compounds of the same, resembling butter in appearance, manufactured from cattle fat or hog fat, or such substances heretofore known as oleomargarine, oleo, oleomargarine oil, butterine, lardine, suine and neutral, all lard extracts and tallow extracts, and all mixtrres and compounds of tallow, beef fat, suet, lard, lard oil, vegetable oil, annatto and other coloring matter, intestinal fat and offal fat, other than that produced from unadulterated milk or cream from the same, any article designed to take the place of butter or cheese, produced from pure unadulterated milk or cream of the same, or any article made in imitation of butter, or when so made calculated, or intencled to be sold as butter or for butter, unless said mantufacturers shall pack said imitation substitute in firkins, tubs or wooden or paper packages, with the true name of said initation substitute clearly and indelibly branded, marked or labeled thereon, or whoever shall sell or offer for sale the same as an article of food, unless said imitation substitute is properly packed in firkins, tubs or wooden or paper packages, with the true name of said imitation substitute clearly and indelibly branded, marked or labeled thereon, shall be guilty of a misdemeanor, and shall on conviction thereof be confined in the county jail not exceeding one year, or fined not exceeding one thousand dollars, or both.

2277. Use of imitation butter in hotels, etc.; penalty. Any hotel or boarding house keeper in this State who shall set before his guests at any meal any compound resembling butter in appearance, manufactured from cattle fat or hog fat, or such other articles, known to the trade as 
oleomargarine, and shall not clearly and legibly mark the vessel in which such compound is served with the words "oleomargarine," or "impure butter," shall be deemed guilty of a misdemeanor, and upon conviction shall be fined in a sum of not less than one hundred nor more than five hundred dollars.

Revised Śtatutes, I899, Vol. I, p. 629.

4744. Imitation butter defined. For the purpose of this article every article, substitute or compound, other than that produced from pure milk, or cream from the same, made in the semblance of butter and designed to be used as a substitute for butter made from pure milk, or cream from the same, is hereby declared to be imitation butter.

4745. Animal fat, vegetable oil and coloring matter in butter substitutes. No person shall combine any animal fat or vegetable oil or other substance with butter, or combine therewith or with animal fat or vegetable oil or combination of the two, or with either one, any other substance or substances whatever, any annatto or compound of the same, or any other substance or substances, for the purpose or with the effect of imparting thereto a yellow color, or any shade of yellow, so that such substitute shall resemble yellow or any shade of genuine yellow butter, nor introduce any such coloring matter or such substance or substances into any of the articles of which the same is composed: Provided, nothing in this article shall be construed to prohibit the use of salt and harmless coloring matter for coloring the substitutes for butter manufactured for export or sale outside the State. No person shall, by himself, his agents or employes, produce or manufacture any substance in imitation or semblance of natural butter, nor sell, nor keep for sale, nor offer for sale, any imitation butter made or manufactured, compounded or produced in violation of this section, whether such imitation butter shall be made or produced in this State or elsewhere. This section shall not be construed to prohibit the manufacture and sale, under the regulations hereinafter provided, of substances designed to be used as a substitute for butter, and not manufactured or colored as herein prohibited.

4746. Brand for butter substitutes. Every person who lawfully nanufacturers any substance designed to be used as a substitute for butter shall mark, by branding, stamping or stenciling upon the top and sicle of each tub, firkin, box or other package in which such article shall be kept, and in which it shall be removed from the place where it is procuced in a clean and durable manner, in the English language, the words "Substitute for butter," in printed letters, in plain Roman type, each of which shall not be less than one inch in length and one-half inch in width. 
4747. Transportation of unbranded butter substitutes prohilited. No person, by himself or another, shall ship, consign or forward by any common carrier, whether public or private, any substance designed to be used as a substitute for butter, and no carrier shall knowingly receive the same for the purpose of forwarding or transporting unless it sha!l be manufactured and marked as provided in the preceding section of this article, and unless it be consigned by the carrier and receipted for by its true name: Provided, That this article shall not apply to any goods in transit between foreign states across the State of Missouri.

4748. Possession of unmarked butter substitutes. No person shall have in his possession or under his control any substance designed to be used as a substitute for butter, unless the tub, firkin, box or other package containing the same be clearly and durably marked, as provided by section 4747 of this article: Provided, That this section shall not be deemed to apply to persons who have the same in their possession for the actual consumption of themselves and family. Every person having in possession or control of any substance designed to be used as a substitute for butter, which is not marked, as required by the provisions of this article, shall be presumed to have known during the time of such possession or control the true character and name, as fixed by this article of such product.

4749. Substitute butter sold as gemuine. No person, by himself or another, shall sell or offer for sale any substance designed to be used as a substitute for butter under the name of or under the pretense that the same is butter.

4750. Penalties. Every person, firm or corporation who shall violate any of the provisions of section $4745,4746,4747,4748$ and 4749 of this article shall forfeit and pay to the State of Missouri, for the use of the school fund for every such violation, the sum of fifty dollars and costs of suit, to be recovered by civil action in the name of the State of Missouri on the relation of any person having knowledge of the facts before any justice of the peace of the city or county where such violation occurs or any other court of competent jurisdiction, subject to appeal to the circuit court, as in other cases; and it is further enacted that every person, firm or corporation who shall violate the provisions of this article, in acldition to the civil liability of the State of Missouri herein provided, shall be deemed guilty of a misdemeanor, and shall for the first offense be punished by a fine of not less than fifty dollars (\$50.00) nor more than one hundred dollars $(\$ 100.00)$ or by imprisonment not excecding thirty days, and for each subsequent offense, by a fine of not less than two hundred and fifty dollars $(\$ 250.00)$ nor more than five hut1dred dollars $(\$ 500.00)$ or by imprisonment in the county jail not less 
than thirty days, nor more than six months, or by both such fine and imprisonment, in the discretion of the court.-As amended March I9, Igor; Lawes of rgor, p. 44.

475I. Certificate of analysis. A certificate of an analysis of any dairy product or adulteration or imitation thereof, when duly signed by a professor of chemistry connected with any of the departments of the State University or Experiment Station, shall, when acknowledged by any person authorized to administer an oath, be received in the courts of this State as prima facie evidence of the facts stated therein, in all civil actions, as provided for in section $475^{\circ}$ of this act.-As amended March I9, I90I; Laze's of I901, p. 44.

4752. Party to violation can not bring suit. No action can be maintained on account of any sale or other contract made in violation of or with intent to violate this article, by or through any person who was knowingly a party to such wrongful sale or other contract.

4753. Removal of marks, etc. Whoever shall efface, erase, cancel or remove any mark provided for by this article, with intent to mislead, deceive, or to violate any of the provisions of this article, shall be deemed guilty of a misdemeanor.

4754. Enforcement of law. The State Board of Agriculture shall be and is hereby charged with the enforcement of this article: Provided, That all fines collected under the provisions of this article shall be paid into the State treasury. Actions under this article shall be brought in any court of competent jurisdiction.

4755. "Skimmed milk" or "not full-cream" cheese must be so labeled. No person or persons, corporation, company or other association or congregation of individuals shall manufacture, sell or offer for sale, directly or indirectly, at retail or at wholesale, in this State any article to be known or denominated cheese, not made from pure cream or tinskimmed milk or cream of the milk, unless such person or persons, corporation, company or association of individuals manufacturing the same, or offering the same for sale, or selling the same, shall brand or label such cheese or article so offered for sale, denominated a cheese, with black letters not less than one inch in length in a conspicuous place and of large size, in the English language, as follows: "Skimmed milk cheese," or with the words "not full cream cheese," giving the true name of such article called cheese so manufactured or offered for sale, clearly and indelibly branded, marked or labeled thereon, so that the same can be distinctly read and fully comprehended at all stores or places or factories where the same may be offered for sale.

4756. "Skimmed milk cheese" and "full-cream cheese" defined. All cheese manufactured, sold or offered for sale in this State at retail or 
wholesale, made from milk or cream of same, which tests not less than three per cent of butter fat, shall be deemed to be a full cream cheese, and all cheese manufactured, sold or offered for sale at any place or in any manner by any person or persons in this State at retail or wholesale made from milk or cream of same testing less than three per cent of butter fat shall be deemed "skimmed milk cheese," or cheese not made from pure unskimmed, unadulterated milk or cream of same.

4757. Pcnalty. Any person or persons who shall violate any of the provisions of section 4755 or 4756 of this article shall be deemed guilty of a misdemeanor, and shall, on conviction thereof in any court of conpetent jurisdiction, be confined in the county jail not exceeding one year, or fined not less than $\$$ Io nor exceeding $\$ 500$, or both.

4758. Transportation of "skimmed" milk" and not "full-cream" checse; penalty. No person, by himself or another, shall ship, consign or forward by any common carrier, whether public or private, any substance designed to be used as a cheese, not made from pure, unskimmed milk or cream of the same testing at least three per cent butter fat, unless such cheese is marked or labeled "skimmed milk cheese," or with the words "not full cream cheese" labeled thereon: Provided, That this article shall not apply to any goods in transit between foreign states across the State of Missouri. Any person violating this section shall be deemed guilty of a misdemeanor, and, upon conviction, shall be fined a sum not less than $\$$ Io nor more than $\$ 500$.

4759. Party to violation of law may not bring stit. No action can be maintained on account of any sale or other contract made with the manufacturer or person offering any cheese for sale in violation of or with intent to violate this article by or through any person who is knowingly a party to such wrongful sale, or other contract for the sale of unbranded skimmed milk cheese or cheese not full cream cheese.

4760. Remozal of labcls, etc.; penalty. Whoever shall efface, erase, cancel or remove any marks or label on any such article or cheese, provided for by this article, with intent to mislead, deceive or to violate any of the provisions of this article, shall be deemed guilty of a misdemeanor, and, on a conviction, be fined in a sum not less than $\$ 50$ nor more than $\$ 500$.

476r. Enforcement of laze. The State Board of Agriculture shall be and is hereby charged with the enforcement of this article: Prosided, That all fines collected under the provisions of this article shall be paid into the State treasury. Action under this article may be brought by information or indictment in any court of competent jurisdiction.

Revised Statutes, I899, Vol. 2, Arts. 5 and 6, pp. I 129-I I3I.

6r65. Cities may, by ordinance, regulate sale of milk. All cities 
and towns in the State shall have power, by ordinance, to license and regulate milk dairies and the sale of milk, and provide for the inspection thereof.

Revised Statutes, I899, Vol. 2, p. I442.

\section{STATE DAIRY COMMISSION.}

SEC. I. State Dairy Commissioner; bond; salary; report. There is hereby created the office of State Dairy Commissioner, and, immediately after this act goes into effect, every two years thereafter, the Governor shall, with the advice and consent of the Senate, appoint a suitable person, to be known and designated as "State Dairy Commissioner," who shall have a practical knowledge of and experience in the manufacture of dairy products, who shall hold his office for two years from the first day of May, or until his successor is appointed and qualified, subject to removal by the Governor for inefficiency, neglect or violation of duty. He shall give bond in the sum of ten thousand dollars $(\$ 10,000)$, conditioned for the faithful performance of his duties, with sureties to be approved by and filed with the Governor. Said commissioner shall receive a salary of two thousand dollars $(\$ 2,000)$ a year, payable monthly, and his actual necessary traveling expenses while in the discharge of his official duties. He shall make an annual report to the Governor not later than January $\mathrm{I}$ of each year, and shall be furnished an office by the State Board of Agriculture at the seat of the State Agricultural College.

SEC. 2. Deputy Commissioner; chemist. The said Commissioner shall have power, when necessary, to appoint a deputy, whose salary shall not exceed $\$ r, 200$ per year, and the necessary chemical work of his office shall be done by the chemist of the State Agricultural College.

SEC. 3. Duties of Commissioner. It shall be the duty of the State Dairy Commissioner to inspect or cause to be inspected all creameries, public dairies, butter and cheese factories at least once a year, and oftener, if possible, prescribe such reasonable rules and regulations for their operation as he deems necessary to fully carry out the provisions of laws now in force or that may be hereafter enacted relative to dairy products for the promotion and maintenance of public health and safety ; compile and publish, annually, statistics and information concerning all phases of the dairy industry in this State; co-operate with the State Board of Agriculture in the holding of farmers' institutes, special dairy meetings, and in general strive for the promotion of the best interests of the dairy industry throighout the State. He shall keep on hand a supply of standard test tubes or bottles and milk measures or pipettes 
adapted to the use of each milk testing machine, the manufacturers or dealers of which have filed with the State Dairy Commissioner a certificate from the director of the Missouri Agricultural Experiment Station that said milk testing machine, when properly operated, will produce accurate measurements of butter fat, and to furnish same at actual cost to any person desiring them, upon written request therefor, such tubes, bottles, measures and pipettes to be stamped with the letters "S. D. C." as certifying to their accuracy. He shall preserve in his office all correspondence, records, documents and property of the State pertaining thereto and turn over same to his successor. He shall devote his whole time to the duties of his office, and, during his term, shall hold no other official or business position nor any professorship in any educational institution.

SEC. 4. Authority of Commissioner-inspections, samplings, reports, examining witnesses, etc. In the performance of his official duty the State Dairy Commissioner is hereby authorized and empowered to enter during business hours all creameries, public dairies, butter and cheese factories or other places where dairy products are sold or kept for sale, for the purpose of inspecting same; to take samples anywhere of any dairy product, or imitation thereof, suspected of being made or sold in violation of law, and cause the same to be analyzed or satisfactorily tester by the State Agricultural College chemist, and such analysis or test shall be recorded and preserved as evidence, and the certificate of such test, when sworn to by such chemist, shall be admitted in evidence in all prosecutions that may result under the operations of this act; to require the owner, agent or manager of every creamery, public dairy, butter and cheese factory to report annually, on or before September Ist for the year ending July Ist, on blanks to be furnished by the State Dairy Commissioner, full and accurate information concerning the quantity of milk bought, sold or used, the average price of same, the quantity of butter or chesse produced or sold and the average price of same, the number of ccws used in of contributing to the operation of such creamery, dairies and factories; to examine under oath or otherwise any person whom he may believe has knowledge concerning the unlawful operation of any creamery, public dairy, butter or cheese factory, to issue subpoena requiring the appearance of witnesses and the production of books and papers and administer oaths with like effect as is done in courts of law in this State, and it shall be the duty of any circuit court, or the judge thereof, upon the application of said commissioner, to issue an attachment for such witnesses and compel him or them to attend before the Commissioner and give testimony upon such matters as he or they shall be lawfully required by such Commissioner, and said court or judge 
shall have power to punish for contempt as in other cases of refusal to obey the orders and processes of the court.

SEC. 5. Definition; penalty for selling milk containing foreign substances. The terms "creameries, public dairies, butter and cheese factories," for the purposes of this act, shall be construed to mean such as produc or manufacture dairy prolucts, either genuine or imitation, for sale either at wholesale or retail to the general public, and shall not include farmers or others who produce a small surplus of such product; in excess of their family needs. In all prosecutions and proceedings for the enforcement in any of the courts in this State of all laws and regulations of whatsoever nature now in force, or that may hereafter be enacted pertaining to the production, sale and distribution of dairy products of any kind whatsoever, the standards of purity and the definition of said products, shall be such as are now, or may hereafter be, adopted, recognized and published by the officials of the United States Department of Agriculture, and whosoever shall sell, or offer or expose for sale anywhere in this State, milk or cream containing any foreign substance or preservative of any kind whatsoever injurious to health, shall be guilty of a misdemeanor, and on conviction be fined not less than ten dollars, nor more than one hundred dollars for each offense.

Sec. 6. Penalty for hindering execution of law. Any person or persons, firm or corporation who shall hinder or obstruct, or in any way interfere with the said State Dairy Commissioner or his deputies while discharging the duties of inspection, or who fail or refuse to make the reports provided for by section 4 of this act, shall, on conviction, be fined not less than ten nor more than one hundred dollars, or imprisonment in jail not less than ten nor more than ninety days, or by both such fine and imprisonment.

SEC. 7. Appropriation. For the purpose of carrying into effect the provisions of this act there is hereby appropriated out of the State treasury, chargeable to the general revenue fund, the sum of ten thousand dollars $(\$ 10,000)$, or so much thereof as may be necessary for paying the salary of the State Dairy Conmissioner and his assistant, and the necessary traveling and printing expenses of same for the years 1905 and 1906.

SEC. 8. Emergency. The advancement of the interests of the dairy industry as contemplated by this act creates an emergency within the meaning of the constitution; therefore, this act shall take effect and be in force from and after its passage.

SEC. 9. Repeal. All laws and parts of laws of whatsoever nature, in conflict or inconsistent or repugnant to the provisions of this act, are hereby repealed.

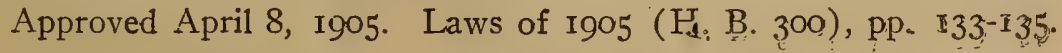




\title{
UNITED STATES STANDARDS.
}

\author{
Milk and its Products.
}

\section{a. MILKS.}

I. Milk (whole milk) is the lacteal secretion obtained by the complete milking of one or more healthy cows, properly fed and kept, excluding that obtained within fifteen days before and five days after calving, and contains not less than twelve (I2) per cent of total solids, not less than eight and one-half (8.5) per cent of solids not fat, and not le's than three and one-quar'er (3.25) per cent of milk fat.

2. Blended milk is milk modified in its composition so as to have a definite and stated percentage of one or more of its constituents.

3. Skim milk is milk from which a part or all of the cream has been removed and contains not less than nine and one-quarter (9.25) per cent of milk solids.

4. Buttermilk is the product that remains when butter is removed from milk or cream in the process of churning.

5. Pasteurized milk is milk that has been heated below boiling but sufficiently to kill most of the active organisms present and immediately cooled to fifty degre:s $\left(50^{\circ}\right)$ Fahr. or lower to retard the development of their spores.

6. Sterilized milk is milk that has been heated at the temperature of boiling water or higher for a length of time sufficient to kill all organisms present.

7. Condensed milk is milk from which a considerable portion of water has been evaporated, and contains not less than twenty-eight (28) per cent of milk solicls, of which not less than one-fourth is milk fat.

8. Srvetened condensed milk is milk from which a considerable portion of water has been evaporated and to which sugar (sucrose) has been added, and contains not less than twenty-eight (28) per cent of milk solids, of which not less than one-fourth is milk fat.

9. Condensed skim milk is skim milk from which a considerable portion of water has been evaporated.

\section{b. MILK FAT OR BUTTER FAT.}

I. Milk fat or butter fat is the fat of milk and has a Reichert-Meissl number not less than twenty-four (24) and a specific gravity not less than $0.905\left(\frac{40^{\circ} \mathrm{O}}{40^{\circ} \mathrm{O}}\right)$ 


\section{c. CREAM.}

I. Cream is that portion of milk, rich in butter fat, which rises to the surface of milk on standing, or is separated from it by centrifugal force, and contains not less than eighteen (I8) per cent of milk fat.

2. Evaporated cream is cream from which a considerable portion of water has been evaporated.

\section{d. BUTTER.}

I. Butter is the product made by gathering in any manner the fat of fresh or ripened milk or cream into a mass which also contains a small portion of the other milk constituents with or without salt, and contains not less than eighty-two and five-tenths (82.5) per cent of butter fat. By acts of Congress, approved August 2, I886, and May 9, I902, butter may also contain additional coloring matter.

2. Renovated or process butter is the product made by melting butter and reworking, without the addition or use of chemicals or any substances except milk, cream or salt, and contains not more than sixteen (16) per cent of water and at least eighty-two and five-tenths (82.5) per cent of butter fat.

\section{e. CHEESE.}

I. Cheese is the solid and ripened product made by coagulating the casein of milk by means of rennet or acids, with or without the addition of ripening ferments and seasoning. By act of Congress, approved June 6,1896 , cheese may also contain additional coloring matter.

2. Whole milk or full cream cheese is cheese made from milk from which no portion of the fat has been removed and contains, in the waterfree substance, not less than fifty $(50)$ per cent of butter fat.

3. Skim-milk cheese is cheese made from milk from which any portion of the fat has been removed.

4. Cream cheese is cheese made from milk and cream, or milk containing not less than six (6) per cent of fat.

\section{f. MISCELLANEOUS MILK PRODUCTS.}

I. Ice cream (schedule in preparation).

2. Whey is the product remaining after the removal of fat and casein from milk in the prccess of cheese making.

3. Kumiss is the product made by the alcoholic fermentation of mare's or cow's milk with or without the addition of sugar (sucrose). 


\section{MILK SUPPLY OF OUR BORDER CITIES.}

St. Louis-A singular situation exists here. Only ten per cent of. the milk consumed in the city of St. Louis, according to City Milk Inspector R. H. Pethebridge, is produced in Missouri the other 90 per cent comes from Illinois, and this in the face of the fact that the Missouri milk is richer in solids not fat, and will, under equal conditions, remain swect about twelve hours longer than the Illinois mik.

A good share of the milk coming into St. Louis from Missouri territory comes over the Iron Mountain railroad from the clean water Ozarks, which explains the superior keeping 'quality of the Missouri milk.

Kansas City and St. Joseph are supplied practically all from Missouri.

\section{RENOVATED BUTTER.}

Figures obtained from the United States Internal Revenue Departpartment show that in the year I905 there was produced in Missouri 469,000 pcunds of renovated or process butter. This butter is merely the poorer grades of country butter, made clean by heating, washing and reforming. It costs the farmer just as much cow food and just as much barn room and work to produce a pound of this poor stuff, worth on the average only I4 cents per pound, as it would to have produced a pound of choice goods, worth on the average 22 cents. per pound. These 469,000 pounds of renovated butter netted the farmers about $\$ 65,660.00$ (in trade.) This amount, if sold at 22 cents per pound, would have brought in \$103,I80.00. A direct loss to the producers of $\$ 37,520.00$, because of careless and unskil'ed methods of handling the cream and making the butter for one year.

There was, however, about twice this quantity of country butter made which was not renovated, some of which sold cheap-for use as butter-and a little for yet less, as soap grease. All figures considered, $\$ 100,000.00$ would probably not be too large a sum to name as the annual loss to the farmers of Missouri on account of poor butter.

\section{WHERE TO PLACE EMPHASIS OF BILL.}

With limited force and funds, what phase of the dairy industry would best be emphasized at the present time in order. to do the most good?

We find at hand a large and wealthy State, producing corn, beef cattle and hogs in quantity and quality superior to most of the states and 
rivaling the few, but producing a very modest amount of dairy goods. Missouri, located as she is in the heart of the United States, handy to markets in every direction, with a soil and climate equal or superior to any of the northern or eastern states, should be engaged more extensively in the production of butter and cheese. It has been said that Missouri is not producing butter and cheese enough to feed her own people. Whether this is correct or not, there is one thing sure, she does not procluce what she might.

Although there is great need for inspecting for adulterated dairy foods, and this will receive attention, it seemed by all means best to lay the principal stress for the first two or three years upon the side of production.

Missouri is now producing about twenty million dollars' worth of butter, cheese and milk a year, but this could be doub'ed without any increase in the number of men or the number of cows engaged in the business, and this without the loss of anything of value that is now gotten from the farms.

The older dairy countries and states have of necessity discovered the most economical and practical methods of feeding, caring for and selecting the stock. When the Missouri farmers adopt these methods they will be able to compete with any state or country with wonderful success.

There being a very great demand for increased production and comparatively little to inspect, the policy of the present Commissioner will be, first, to encourage production; second, to work with the butter-makers and cheese-makers to help them to put out a better grade of goods; and, third, to inspect for adulteration and fraudulent sales.

\section{WHAT HAS BEEN ACCOMPLISHED.}

Since the first of August, I905, the Dairy Commissioner has devoted his time almost exclusively to the production end of the business. In co-operation with the State Board of Agriculture, he has attended one huindred thirty (I30) farmers' institutes and special dairy meetings, and addressed about twelve thousand ( $(12,000)$ people. The subjects usually discussed were, "Why Missouri Farmers Should Do Dairying as a Side Line of General Farming;" "How to Get the Most Out of the Cow You Now Have;" "How to Build a Dairy Herd With Small Capital;" "The Silo, and How to Build It;" "Better Butter on the Farm;" "How to Make a Fine Cheese on the Farm at Almost No Expense;" "Stable Construction for Convenience and Sanitation;" "Testing Milk;" "Care of Milk;" "Economical Feeding," etc. The demand for speakers on the subject of dairying has been greater than could be supplied. 
Creameries and cheese factories have also been visited by the Commissioner while he was doing institute work wherever it was possible to do so. It was frequently found that a word of instruction to the maker or to the manager was needed. The larger portion of the factories were visited and inspected for sanitary surroundings by the Deputy Dairy Commissioner, data gathered and instruction given.

The wholesale dealers in butter and cheese were called on by the Deputy Commissioner, who gathered facts concerning the amount of goods shipped into the State; the prices and the times of year, the intent being not to pry into another's business, but to learn our own. I wish here to publicly thank these commission and wholesale merchants for ine courteous manner in which they have aided this Department.

Inspection for adulteration has not been pushed yet. That is the phase to be commenced this winter. There is abundance of work to be done, especially in our large cities.

\section{MISSOURI CREAMERIES.}

Agricultural College, Columbia.

Altenburg Creamery Co., Altenburg.

Alma Creamery Co., Alma.

Arcadia Creamery Co., Arcadia.

Ash Grove Creamery Co., Ash Grove.

Bethany Creamery Co., Bethany.

Billings Creamery Co., Billings.

Blue Valley Creamery Co., St. Joseph.

Carpenter \& Schaffer Manufacturing Co., Butler.

Carrollton Creamery Co., Carrollton.

Colonial Creamery Co., St. Louis.

Concordia Creamery Co., Concordia. .

Clearmont Creamery Co., Clearmont.

Clinton Creamery Co., Clinton.

Corder Creamery Co., Corder.

Durham Creamery Co., Durham.

Enma Creamery Co., Emma.

Foristell Creamery Co., Foristell.

Friestatt Creamery Co., Friestatt.

Frohna Creamery Co., Frohna.

Gold Bell Butter Co., Greenridge.

Hamilton Creamery Co., Hamilton.

Hannibal Creamery Co., Hannibal.

Holden Creamery Co., Holden.

Joplin Creamery Co., Joplin. 
Kirksville Creamery Co., Kirksville.

LaGrange Creamery Co., LaGrange.

Lewis Creamery Co., St. Joseph.

Liberal Dairy Co., Liberal.

Mansfield Creamery Co., Mansfield.

Meriden Creamery Co., Kansas Citỹ.

Missouri-Kansas Manufacturing Co., Joplin.

New Era Creamery Co., New Melle.

Nixa Creamery Co., Nixa.

Oakton Creamery Co., Lamar.

Ozark Creamery Co., Springfield.

Palmyra Creamery Co., Palmyra.

Saline County Creamery Co., Marshall.

Stewartsville Creamery Co., Stewartsville.

Sweet Springs Creamery Co., Sweet Springs.

Western Dairy Co., St. Joseph.

\section{THE CO-OPERATIVE CREAMERY IN MISSOURI.}

There is probably no rural enterprise which gives greater satisfaction to its members than a co-operative creamery when it prospers, neither is there any which is remembered longer than one that has proved a failure, whatever the cause of the failure may have been.

Fcr the past ten or fifteen years, more or less actively, farmers and townsmen of a community have joined hands to build an enterprise of this nature. Very seldom, however, did any people organize and build of their own free will. They are ustrally talked into the scheme by promoters, who, not caring for the future of the concern, promoted wherever they could. Consequently, a great many factories were built which never should have been, in places not yet ready for this intensive kind of farming. There not being business enough to make it pay to run the factory, it was closed, and the remains are still to be seen all over the State, still standing as monuments to the greed of a set of building sharks. In many places the dairy business, as an industry, is blamed for the acts of these men. In many cases plants worth $\$ 2,000$ to $\$ 3,000$ were put out for $\$ 4,000$ to $\$ 6,000$. The producers became disgusted and the business received a "black eye," which has lasted for several years and still remains.

Those few that did weather the hard timis incident to getting well established have been of very material benefit to their communities, and will receive every possible encouragement from this office. It is hoped that in time every pound of creamery butter and factory cheese made in Missouri wil be made in the farmers' co-operative factory. 


\section{WHEN TO BUILD THE CO-OPERATIVE CREA;MERY.}

Any farming community of Missouri, near a railroad, where 500 or more cows can be found within a radius of 5 miles from the factory, the owners of which will guarantee to support th? enterprise with the entire quantity of cream from these cows, is in a position to consider the establishment of a butter factory.

The cost of making a pound of butter increases as the quantity made decreases. The following table* shows the average cost of manufacture for different runs.

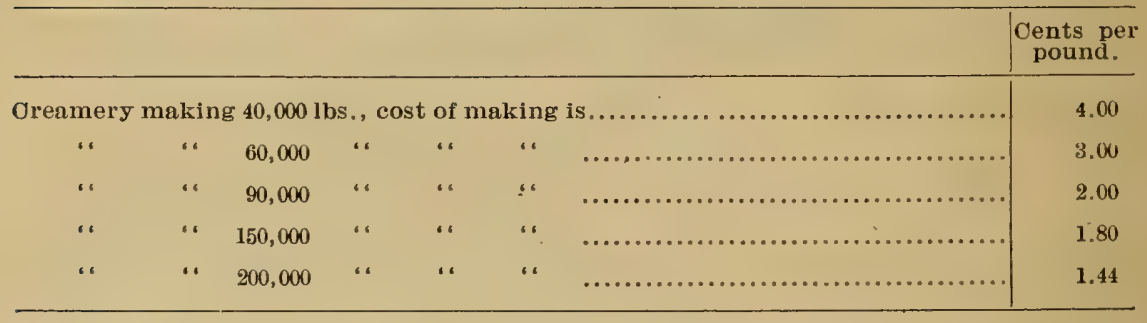

Whenever the quantity made runs below, 60,000 pounds a year and the cost of making runs above 3 cents a pound, exceptionally good management only can save the business. About 400 cows will supply this amount. When only 200 or 300 cows can be found, it is very unwise to build with the expcctation that the remaining number will soon come. It doesn't wcrk that way. The farmers 'wait to see the success of the venture before getting in more stock. A creamery for 500 cows need not cost over $\$ 3,000$.

\section{THE CENTRALIZED CREAMERY.}

This institution of modern times has been, and is still being fought in many localities, especially in the northern states where the farmers' co-operative creameries have proved successful. In Missouri conditions are different. Long summers and short mild winters, with fertile land, have led the people into the production of beef, corn and hogs to such an extent that until recently comparatively few farmers, five to a dozen in each community, have cared to run the dairy even as a sound side issue. These few could not build and operate a co-operative creamery successfully, so were forced to sell their country-made butter

-Report, state Dairy Oommissioner, Iowa; 18, p. 33. 
at the grocery and take what they could get, and take that in trade: This is no longer true. There is hardly a town in the State but is in the territory of one of the big centralized creameries which buy the cream and pay cash for the fat contained in it, and at a price that usually makes the cream more valuable than the finished butter if the farmer does the finishing.

Several small towns in the State now have the co-operative creamery fever. It is safe to say that most of these places are not now in need of a co-operative creamery, but co-operatize preparation for a creamery.

It requires several years to build a herd of dairy cows, and longer yet to build a dairy sentiment. Let those few who now wish to pursue the industry get hand separators and ship cream to some one of the many large crameries. They will realize as much net profit as they could with a local plant, and then in five or ten years, when the spirit is stronger and good cows more numerous, a farmers' creamery should be encouraged.

To hold the dairyman that we have while their neighborhoods are being developed, let this be the mission of the centralized creamery.

\section{THE HAND SEPARATOR.}

The hand cream separator is a very potent factor in Missouri dairying. It came slowly at first, but of late very rap.dly. There are already several thousand in use in the State, and the number is rapidly increasing. They have come to stay, and have brought additional prosperity with them. Now any man with ten ordinary cows, who is where he can patronize a creamery, either centralized of local, cannct afford to be without one. The extra cream saved in one year over the deep can or crock system will usually pay for the machine, and the machine, if treated decently, will last ten or fifteen years. There are half a dozen makes of separators on the market. Competition has forced them all to become good and to stay good. The farm separator is now to the dairy farmer what the twine binder is to the grain farmer. It is still possible to cut the grain with the cradle, but it would not pay to do it in that way, so can the milk producer make some money in the old way of raising cream, but it doesn't pay.

\section{WESTERN BUTTER CONDITIONS.}

The time was when western butter had a poor place on the market. Gathered cream butter was often pretty poor stuff. Methods of manufacture changed, and the time was when western butter commanded top 
price. This was when the farmer brought the whole, sweet milk to the factory, and the operator madz the cream as well as the butter. Now, the time is when the buyer wishes to be shown the goods if they are from the west. There is no dodging the fact that a very large per cent of the butter made in our western creameries is poor, poor bicause the cream from which it is made was poor. Seeing this, it has been the pleasure of many writers to take a whack at the farmer, holding him responsible for all this trouble and loss. The truth of the matter is, the separator agents and the creamery managers are more to blame than the farmer for the poor cream that the farmer sends in.

The Separator-There is no question about the hand separator be-ing an economical instrument for the farmer who sells cream. So long as this remains true there is no use in trying to keep him from using one. Neither should we try, for anything which makes more money for the producer will encourage him to stay in the business; this insures continuance of work for the manufacturer and greater business. Moreover, it is both theoretically and practically possible to make just as good butter from hand separator cream as frcm power separator cream. Yet the fact remains that such good butter is not usually made.

The farmer has been scolded a d shamed at and thoroughly "lam. basted" for not taking better care cf his cream, and with what result? Poor cream continues to come and bad butter continues to go.

The Separator Agents.-The hand separator agents who have taught and are still teaching the farmers that once or twice a week is often enough to wash their particular make of machine should be the first men laid out, and with them the company they represent, for allowing them to do this thing, which, in most cases, is against the orders. of the house. So much has been said on this point, and the agents themselves know the truth so well, that I was surprised at learning frcm one whose word cannot be questioned that at the Implement Dealers' Convention in Kansas City, Missouri, this winter, the agent of a separator company was heard to tell a farmer that his machine was "washed with the crank." We all know and he knew that any and all machines, or tools used about milk, must be well washed if first-class goods are to be produced, or in other words, this man then and there sold his honor as an honest man for the price of his commission on a cream separator. For a temporary personal gain he jeopardizes the whole industry. Is it not almost time the State Dairy Inspectors were placed on the trail of these men, and at least publicly expose them and their company when such criminal nearsightedness is practiced? Their teaching is more filthy and a greater source of evil than the farmer's dirty barn.

The Creamery Manager.-The second man to be censured is the 
creamery manager, for he, though howling most lustily, is after all the chief offender. His sin lies in accepting at first-class prices cream which no mortal man could make into good butter. In fact, the competition among the creameries of the west has been too keen for the permanent welfare of any, even the producers. During the past two years their mad chase for more business has led all to take any old stuff named cresm, and what is worse, pay a good cream price for it. There is in man a trait which keeps him from putting into any article any more work than is necessary to get the price out of it, and why should he? Last summer the creamery companies sent out personal appeals and instructions by the cartload to the farmers to take better care of the cream, but to no use.

A Case.-In a little town in Eastern Kansas one day last summer a farmer brought in a can of ideal cream. This man was well known as a neat farmer. While he stood there talking with the station operator a slovenly, unkempt, dirty farmer came in w.th some cream as badly off flavor as himself. One cream was fit for the table and one fit for the sewer, yet the same price was paid for each. One man went away contented in his dirt and the other disgusted at the inconsistency of the creamery manager.

Inspection is often recommended, and it might do some good, but in my opinion such inspection should not be made. The people who buy the goods should do their own inspecting and grading. When the farmer sells smutty wheat, or musty corn or scabby potatoes or rusty apples or stale eggs, he gets a price according to the value of the goods delivered, and this without any official inspection.

Healthy competition to keep up prices is a gcod thing, but a warlike competition to get stuff at any cost, even in any condition, may prove worse than no competition, even to the producer. If quality has value, as we all know it has, it should be paid for. It is now up to managers of the creameries, both large and small, to grade cream in fact as well as in words, and make a good substantial difference between first-grade and second-grade stuff. When the creameries thus give backing to their own words concerning the value of better cream, the farmers will give that extra care necessary to have good cream.

Pay for Quality.-A difference of 4 cents per pound fat between first and second grades would seem to be just and have the desired effect.

All creameries, both large and small, should agree to live up to these or some similar rules, and then do it.

Western butter is now standing trial; the creamery managers are the jurors who will decide its fate. 


\section{THE FARMERS' PART IN MAKING MISSOURI A GREAT DAIRY STATE.}

The production of bulk alone does not prove greatness in any line of industry, there must also be quality.

The farmers of this State are rapidly coming to the front in the matter of large production of butter. This State will, in a very few years, be a leading state in this line. But how about the quality? It is a well known fact that better butter is usually made where the whole milk is brought to the creamery and there skimmed. In several states a fight is still going on; the butter-makers trying to keep the farmers from using hand separators, and for the simple reason that a large majority of the farmers who use hand separators are not sufficiently careful in the keeping of the cream, and do not deliver it often enough. The result is a poor cream and a poorer, and therefore, a cheaper butter. The price of butter depends on its quality, and it is impossible to make a first-class butter from a second or a third-class cream. The difference in price is frequently from one cent to three cents per pound. The simple facts are these: the butter-maker has gone just about as far as he can alone in the matter of making good butter; from this on increased quality and increased price will depend on the farmer.

The hand separator has come and to stay, because it is a good and economical instrument for the farmer. This is especially true in Missouri. Too frequently, however, this privilege of lighter work and less frequent delivery has been abused. The cream is allowed to stand so long under poor conditions that no man could make choice butter from it. It is now up to the farmer to produce a better cream or be content with less money. It costs just as much cow food and wcrk to produce a pound of ten-cent butter as it does a pound of twenty-cent butter. It is to be hoped that cream will soon be graded and paid for accordingly, the same as wheat or corn.

\section{HOW TO CARE FOR CREAM ON THE FARM.}

Ist. Keep the cows clean; don't let them lie in their own filth in the yard or stable, nor wade in stagnant ponds in the pasture. It is impossible to strain the germs out of milk when once they are in. One teaspoonful of cow manure contains about twenty hillion germs.

2nd. Keep the separator clean. Wash it nfter each using. Use a brush and get into the corners. Wash in warm, soapy water, then rinse in scalding water, then let the pieces dry by their own heat. A separator 
that is so washed that it feels smeary or sticky is not clean. Such a machine, and one left standing over night dirty, will be sowing "stink germs" in every bit of cream that goes through it.

3rd. Cool the fresh cream before mixing with the old, and keep all as cool as possible while collecting, then deliver it before it spoils.

\section{VARIATIONS IN TESTS OF CREAM.}

"Why do different lots of cream from the same separator vary so much in per cent of fat?" This is a very common question asked at Farmers' Institutes all over the State. There are several causes for this variation.

I. Speed of the separator-

The faster the bowl turns the richer the cream, slower the thinner. Sometimes the man does the turning, then again a weaker person, the woman or a child, has the work to do. Sometimes the one turning feels lazy, and at other times is physically excited. Time the machine with the watch.

2. Rate of inflow of the milk-

The faster the milk goes in, the thinner the cream. If the milk hopper is kept full all the time the extra pressure carries the milk through faster than when it is low in the can. If machine runs empty a few times during a separation the cream will be richer.

3. Per cent of fat in the milk-

A richer milk gives a richer cream. The milk of a whole herd of cows may vary as much as one-half per cent between morning and night. The heat and excitement of the day tends to, increase the per cent of fat present. Any unusual excitement causes a similar temporary rise in fat. Most cows give more milk in the morning, but richer milk in the evening.

4. Temperature of the milk when separated-

Any decrease in the size of the hole out of which the cream is delivered from the bowl will increase the per cent of the fat in the cream. Cold cream sometimes thus clogs the passage and causes a richer cream to be delivered.

5. Acidity of the milk-

A half sour milk may cause a thin cream. If night's milk is left to be separated in the morning in summer, it very often sours to that extent that when separated the fine clots and fibres of curd cling to the outer wall of the bowl and clog the exit of the skim milk, thus forcing some of it into the cream spout, and in consequence a thin cream is secured. 
6. Adjustment of cream screw-

This may have jarred or bzen turned by some one without the knowledge of the one complaining.

7. Cream will rise on cream-

And if the top be poured off to make butter for the home, the portion sold is thinner than the average. This is occasionally done knowingly by the farmer to test the man who tests the cream.

8. Hand skimmed cream is very variable-

Thick from pans and crocks and thin from deep cans. It is also next to impossible to so skim that the same amount of skim milk will be put into the cream vessel each time. The best test for a market cream is thirty-five to forty-five per cent.

The man who does public testing must know his business, and then have enough confidence in himself and enough natural sand to stand by his figures, no matter what they read.

\section{THE TESTING OF CREAM.}

This is not an especially difficult task, but must be understood, or errors will be made by those of the best intentions. The following are the chief causes of inaccuracy :

Ist. Gross sample not a true one, because

(a) Cream sour and clotted.

(b) Cream dried on surface.

(c) Cream partly churned.

(d) Cream good, but not well mixed before sampling.

2nd. Test bottle sample not correct, because

(a) Cream measured instead of weighed. (I8 grams required.)

(b) Cream weighed with inaccurate scales. (Keep all bearings free from rust and gum.)

(c) Of slovenly work in weighing.

3rd. Acid mistakes-

(a) Too much or too strong acid (burns fat).

(b) Too little or too weak acid (leaves white curd specks in fat).

(c) Acid too warm (burns fat; 55 to 65 degrees F. works best).

(d) Acid poured through cream (burns in clots).

(c) Acid not well mixed when shaking is commenced (burns in clots). 
4th. Mistakes in whirling-

(a) Speed too slow (I2-inch tester requires I,200 revolutions; 24-inch tester requires 800 revolutions).

(b) Not turned long enough ( 5 to 6 minutes necessary).

(c) Bottles too cool while turning (fat cannot rise; should be 150 degrees $F$. for cream and 200 degrees $F$. for skim milk).

5th. Mistakes in adding water-

(a) Water too cold ( 150 to 200 degrees F. right).

(b) Water dirty (causes gray cloud below fat).

(c) Water hard (the lime in hard water often causes unreliable results; use rainwater or condensed steam).

6th. Mistakes in reading fat-

(a) Reading too hot (fat expanded; I 20 to I4O degrees F. right).

(b) Reading too cold (fat contracted, not volume enough).

(c) Upper surface of fat not leveled (a few drops of amylic alcohol on top of fat makes a flat surface of the concave one. This applies to cream only).

7 th. Inaccurate graduation on test bottles-

(a) Every bottle should be tested.

When so small a quantity of cream has to represent so large a quantity it is exceedingly important that every step in the process be performed with the utmost care.

\section{CORRECTION TABLE.}

Weight of milk and cream delivered by a 17.6 c. c. pipette:

\begin{tabular}{|c|c|c|c|c|}
\hline \multicolumn{2}{|c|}{ Per cent, fat in cream. } & \multirow{2}{*}{$\frac{\underset{60}{\text { Specific gravity }}}{1.031-3}$} & \multicolumn{2}{|c|}{$\begin{array}{l}\text { Weight delivered. } \\
\text { Grams. }\end{array}$} \\
\hline \multicolumn{2}{|c|}{.Whole milk.. } & & \multirow{11}{*}{-} & 18.0 \\
\hline \multicolumn{2}{|c|}{10 cream.... } & 1.023 & & 17.9 \\
\hline & “ $\quad \ldots .$. & 1.012 & & 17.7 \\
\hline & “ $\quad \ldots$. & 1.008 & & 17.3 \\
\hline & $" \quad \ldots$. & 1.002 & & 17.2 \\
\hline & “ & .996 & & 17.0 \\
\hline 35 & “ $\quad \ldots$ & . .980 & & 16.4 \\
\hline 40 & " $\quad \ldots$ & .966 & & 16.8 \\
\hline 45 & “ $\quad \ldots$. & .950 & & 16.2 \\
\hline & " $\quad \ldots$. & .917 & & 16.8 \\
\hline \multicolumn{2}{|c|}{ Pure fat... } & .900 & & 15.0 \\
\hline
\end{tabular}


Therefore, cream must be weighed into test bottle, not measured. If cream test 25 per cent when meansured by I7.6 c. c. pipette, it should read 26.4 per cent; if 30 per cent, it should be almost 32 per cent, etc. The whole test is based on 18 grams, not on any number of cubic centimeters; therefore, 18 grams cream is necessary for accurate work. An 18 c. c. pipette is somewhat better. It is practically correct for cream testing between 26 and 30 per cent fat, but is quite inaccurate on cream testing from 40 to 50 per cent, and is also useless as a measure when the cream is filled with gas or air bubbles.

\section{MORE BUTTER THAN BUTTER FAT.}

Another frequent query is regarding the amount of butter a given amount of cream will make. The test gotten at the creamery is for butter fat, not for butter. Butter is not all fat. It contains from io to 20 per cent of water, from 2 to 3 per cent of salt and from I to 2 per cent of casein of cheesy matter. In general, 6 pounds of fat will make 7 pounds of butter, but whether it does that or more, will depend on

I. Acidity of cream when churned-

If cream is not sour enough, fat may be lost in the buttermilk, and thus-lessen the overrun.

2. Temperature of cream when churned-

If too warm the amount of fat lost in the buttermilk will be great and the yield lowered.

3. Amount the butter is worked-

If worked much the water may be worked out and the butter left dry, or with only Io per cent of water, while less working or working in water may leave a wet butter, or one containing as high as 20 per cent water.

4. Size of churn and amount of cream-

If the churn is too large for the amount of cream, considera-

ble cream may be lost by sticking to axis of the churn: This is especially liable to occur. with thick cream in small quantities.

5. Accuracy of the scales-

On small amounts of butter the degree of accuracy of the scales used may introduce an apparent discrepancy. 


\section{MISSOURI CHEESE FACTORIES.}

Agricultural College, Columbia.

Bolckow Cheese Co., Bolckow.

California Cheese Co., California.

Cowgill Cheese Co., Cowgill.

Gem Cheese Co., Cameron.

C. H. Hammond Cheese Co., Mabel.

Model Cheese Co., Cameron.

Newark Cheese Co., Newark.

Johnson Brothers' Cheese Co., Denton.

Knox City Cheese Co., Knox City.

\section{THE CO-OPERATIVE CHEESE FACTORY.}

A great many cheese factories have been built in this State. A few of these are still running. As in the case of the butter factories, too much was often paid for the plant, but because of the fact that a cheese factory can be made to pay well with a patronage less than half that of the creamery, they were for a time quite successful. Of late years they have been closing their doors. Why? Sometimes because the centralized creameries were able to offer the farmers more for their product than could be realized at the cheese factory. This has been especially true with small plants on or near the railroad, where it was easy for the farmer to ship his cream and keep the skim milk at home for pig feeding purposes; while many other companies were unable to pay the farmer a sufficient price for his milk on account of low price received for the cheese when sold. This low price was the result of poor quality in the cheese, and this in turn to inadequate equipment for manufacture and to poor milk received.

There are many sections in Northern and Western Missouri where the stock is compelled to run into stagnant ponds for their drinking water. This water soon becomes foul. Whenever a cow wades in she gets her udder, teats and legs covered with this slime. The organisms that produced the odor in the pond water grow in the milk, and the cheese made from such milk develops a wonderful array of bad smells. If the stock were fenced out of the ponds and made to drink from a tank below, much of this objectionable feature would be overcome. In a few sections of the State, in wet seasons, it is next to impossible to keep the cows clean from mud, and without clean milk a good cheese and a good price are impossible. These sections should patronize a creamery where 
the evil effects are less apparent. The Commissioner will not encourage the crection of cheese factories in the muddy or pond water districts, nor on the railroads anywhere in the State, but he will gladly do all in his power to help those that are established to become more profitable.

\section{THE OZARKS OF MISSOURI THE SWITZERLAND OF AMERICA.}

There is no place in the country better adapted for the production of high grade cheese than this pure water, clean pasture district.

A very large per cent of the cheese consumed in this State is made in Wisconsin and New York. With the long cold winters and short hot summers in the northern states, Missouri can compete very successfully in cost of production, while the long grazing season and pastures free from mud, and provided with fine grass and running water, as pure as the sun ever shone on, will guarantee a high quality.

There are now few, if any, cheese factories in operation south of the Missouri river in this State. All through this section cheese is retailed at 20 cents per pound, yet the producer up in the northern states gets only 9 or ro cents for it. There is room for a good profit.

There is no other side line in agriculture that will pay the average South Missouri farmer so good and so sure a profit as producing milk for a cheese or butter factory.

In the pond-water sections of the State and on the railroads anywhere cheese factories will have a hard time to compete with the great centralized creameries, but in South Missouri and off the railroads ten or more miles cheese factories should be installed. There are in South Missouri sixteen county seat towns that are ten or more miles from the railroad. In every one of these the enterprising men of the community, who have the prosperity of their home at heart, should investigate the cheese business.

In such an inland town a $\$ 1,500$ cheese factory is far more likely tc succecl than a $\$ 5,000$ butter factory. The butter factory would require 500 or more cows to give it a reasonable show for life, while Ioo cows are enough to start out with in a cheese factory.

There are many hills in South Missouri that should always be kept in pasture, but this is no hardship. At Billings, Christian county, Missouri, the pasture gave a return of $\$ 16.50$ per acre per year for cream sold, while the wheat land yielded only $\$ 5.50$ per acre. The land will improve if pastured, and will gradually wear out and wash away if plowed. 
The Commissioner is prepared to furnish first-class operators and men to install the machinery as soon as the local people come forward with that which they only can do. He is ready to correspond with the people in any community that contemplate putting in a factory.

\section{WHY THE MISSOURI FARMER SHOULD DAIRY.}

It is not meant nor recommended that he engage in it to the exclusion of the other phases of farm work, but that he should make it one of the lines of work, one link in the chain of farm operations.

No farm is complete without stock to consume the roughage, and of all the live stock family the dairy cow is the best paying, most economical member.

\section{MONEY IN IT.}

I shall be thoroughly American in this discussion, and name as the first reason: Because there is money in it-more money for the amount of capital invested than in any other work in which the general farmer of Missouri could engage.

Dairying, as compared with general farming, is a special industry, and a special industry demands a special training, a special equipment. All special works receive special wages. The bricklayer gets more than the hod carrier, the engineer more than the fireman, the conductor more than the brakeman, the surveyor more than the shoveler, the dairy farmer more than the general farmer. Men in this world are not paid in proportion to the amount of physical work they do, but for the responsibility they take, the amount of thought they put into the business. The dairy farmer that will put the most good thought into his work will take out the most money. Butter or cream, in proportion to what food there is in it, brings a very high price. It is a very concentrated form of wealth. A ton of timothy hay is usually worth seven dollars, a ton of butter is worth from $\$ 400$ to $\$ 500$, yet one ton of timothy hay has in it as much plant food as twelve tons of butter.

A farmer with 160 acres of land and twenty ordinary cows, well cared for, can sell from $\$ 400$ to $\$ 800$ worth of cream or milk each year and still raise just as much beef, corn, hogs and oats as he could have done if he had not sold a cent's worth of butter fat.

When there is any reasonable market there is a net profit of from $\$ 10$ to $\$ 50$ on each cow each year.

In Harrison county, this State, four years ago, there was no dairyirg worth the name; now the cream and butter shipped out of that contint anounts to about $\$ 12,000$ a month. This $\$ 12,000$ is but the reward for 
faithful and skillful labor. The farms are not made poorer by the loss of the cream, while $\$ 12,000$ secured for wheat or corn would mean tinat the farms of that county had become about $\$ 3,000$ poorer.

Again, it has been shown many times that hogs can be raised much cheaper where skim milk is obtainable. Pigs fed on corn and skim milik will make twice the gain that pigs fed on corn and blue grass pasture or corn and clover pasture will. This milk, to be the greatest value, need be fed in about the proportion of one part milk to five parts corn. Calves grow practically as well on skim milk and corn as they could on whole milk. Why should we not dairy?

\section{RICHER SOIL.}

Reason two why we should dairy-Dairying is the only system of farming that will maintain the fertility of the farm without the use of high-priced chemical fertilizers. For two reasons does dairying maintain the land: First, because in butter there is almost no plant food of value; and, second, because about 90 per cent of all the grain feeds purchased for the cow, as well as 90 per cent of all the food raised on the farm and fed to the cows, is returned in the manure. With barnyard manure and an occasional crop of clover or cow peas the land will remain productive indefinitely. Did you ever stop to think that whenever you sell wheat or corn or oats and get one dollar you lose about thirtyfive cents of your farm just as truly as though you had shoveled up so much soil and thrown it into the ocean, and that when you get one dollar by the selling of butter you lose less than one-half cent's worth of soil?

The land owner who makes his money selling the soil fertility, and in ten or fifty years leaves the farm worn out, is not a farmer, but a soil robber.

He holds the same relation to the soil that a timber thief does to our forests. The tillers of the soil in the future will find that their fathers have not been kind to them. That they have inherited barren patclics of earth, and must build a farm into these acres before a reasonable crop can be grown. We should dairy then because there is present money and future farm in it.

\section{GOOD INFLUENCE ON THE CHILDREN.}

The third reason, and by no means the smallest one, is the good influence the work will have on the growing children. Every morning and every night, fourteen times a week, 730 times a year, the milking must be done, and on time. Such a work must of necessity instill promptness 
and system into the worker, which will be valuable in all future life, no matter what line of industry he follows. A few momentary pleasures will have to be given up, the neighbor boys will play ball without you when, after school, the milking must be done, occasionally a Saturday's fishing or skating will have to be given up to the work of hauling dressing to the fields for next year's crops. But these disappointments are but trivial when compared with the life-time of good that results. There will not be so many nail-keg politicians and dry-goods-box philosophers in a dairy district, but the country will be better off with these gone.

Again, the child that is raised among live stock and taught to be kind to them, to feed them when they cry for food, and to sympathize with them when they are in distress, will grow to be a better citizen and better home-maker than those raised on grain farms or in shops where the inanimate thing is continually being handled. Did you ever see a cityraised child in the country who would not club the horses tied in the stall, beat the dog, stone the pigs, and in every way be cruel and not realize it? I have seen such children.

Why should the general farmer of Missouri go into the dairy business?. Because there is present money in it; because there is future farm and home in it, and because boys and girls raised on the dairy stock farm are more likely to be strong, kind, independent and useful men and women than those raised on farms where the work is irregular and the things handled inanimate.

\section{FARM LABORERS NEEDED.}

From one end of this great State to the other there comes one long call for faithful, competent farm laborers. Many men are met who say, "I know what you say is true; dairying is a good thing; it helps the pocket and it helps the land, but where can I get hired men who will milk or who know how to do it right if they do attempt it?"

Years of prosperity and great building enterprises have called the people to the cities in such numbers that the country is today without a sufficient number of workers. City laborers hired in the country are so green, so incompetent and often so untrustworthy that they are employed under protest and let go as soon as possible.

Missouri, as a whole, needs farm laborers. The dairy farmers in particular, need them; strong, competent, faithful fellows, like the English, Scotch, Danes, Swedes, Norwegians, Germans and Swiss, who are born to the work and who take pride in doing it well, and who will make good, loyal, law-abiding citizens. 
A strong, broad-gauge effort should be put forth by some department of the State to encourage this industrious class of laborers to settle in this State. Why not increase the force in the Bureau of Labor so that one or two men could put in their entire time at selecting immigrants and finding employment for the better class in this State?

\section{BREEDERS OF DAIRY STOCK IN MISSOURI.}

The following is as accurate a list of the breeders of dairy stock in Missouri as could be obtained. The Brown Siviss list is probably not complete, and the Jersey list is old and not absolutely correct.

The Brown Swiss, the Devon and the Red Polled cattle, though here named as dairy breeds, are, more accurately speaking, "dual" purpose animals.

AYRSHIRE.

None in the State.

BROIVN SIVISS.

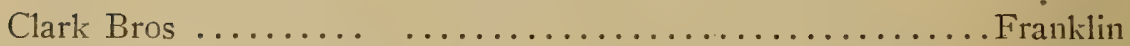

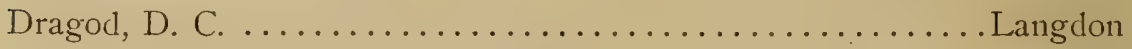

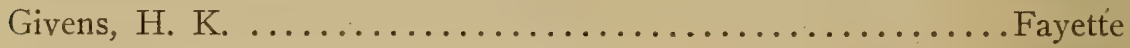

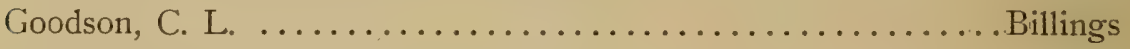

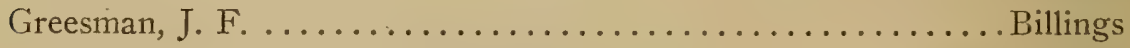

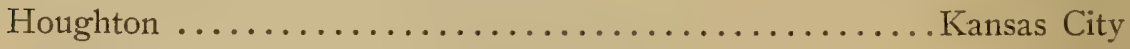

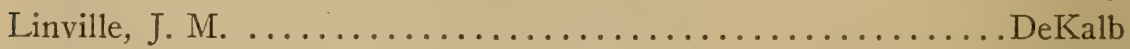

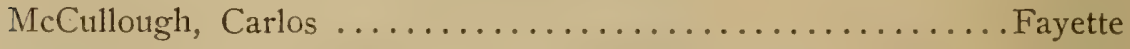

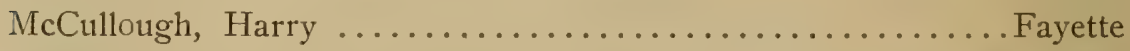

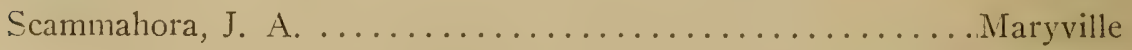

DEVON.

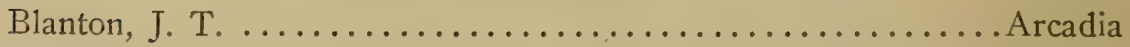

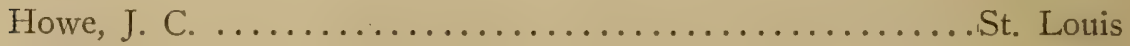

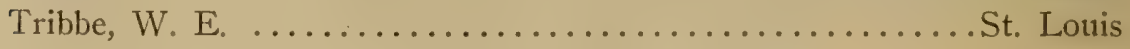

DUTCH BELTED.

None in the State.

GUERNSEY.

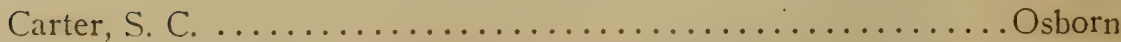

Wheeler, G. C. .................................. 
HOLSTEIN-FRIESIAN.

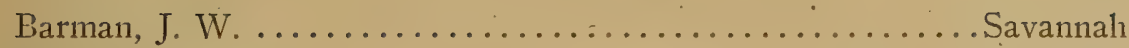

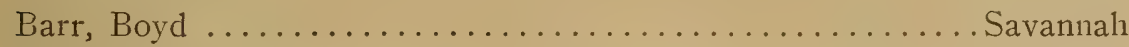

Bean, B. L. ......................................

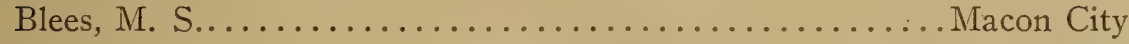

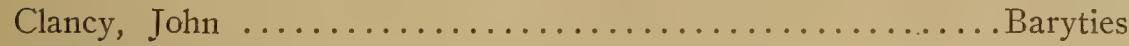

Doughty, M. C. \& Son....................... Farmington

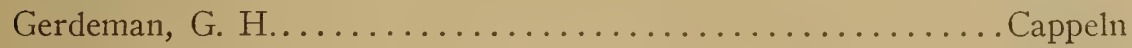

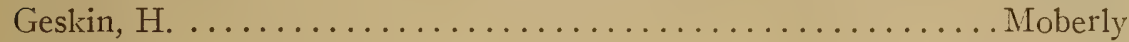

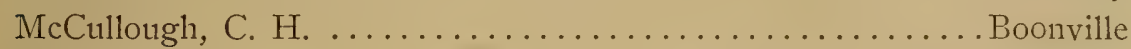

Maguire, R. W. ...............Wainwright Bldg., St. Louis

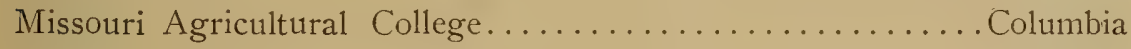

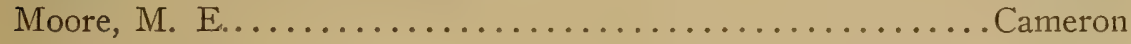

Mosher, Geo. C. ...............605 Bryant Bldg., Kansas City

St. Stanislaus Seminary ..................... Florisant

Shepard, C. P. ...................... Hughesville, R. D. 2

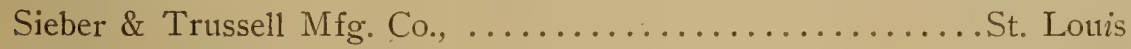

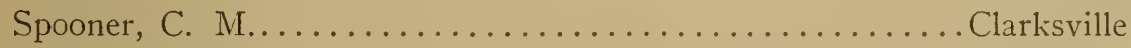

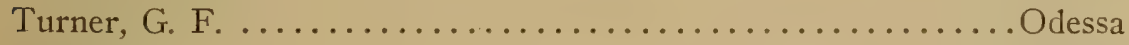

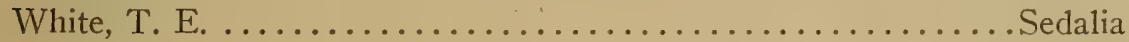

JERSEY.

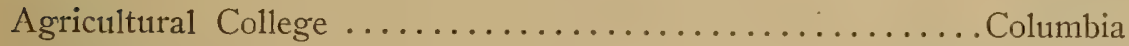

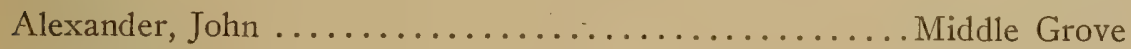

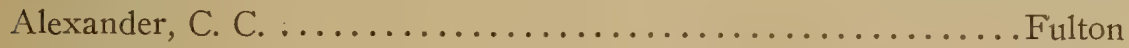

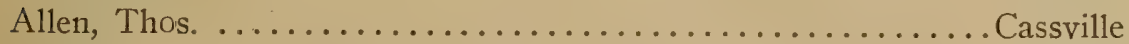

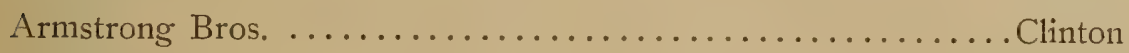

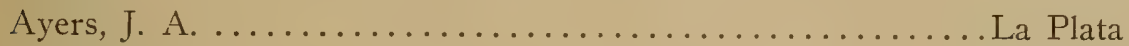

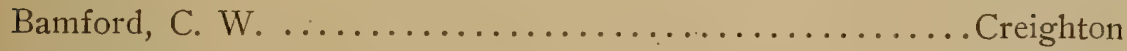

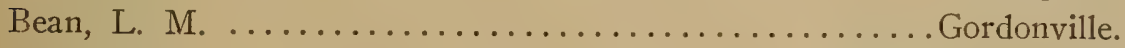

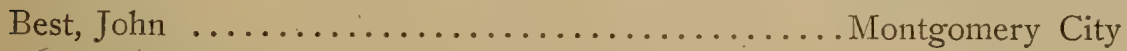

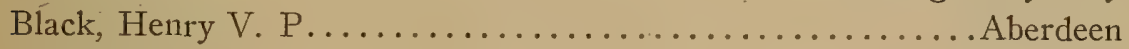

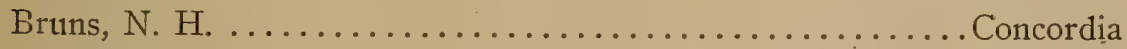

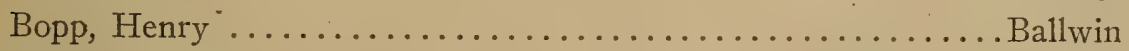

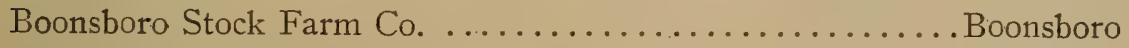

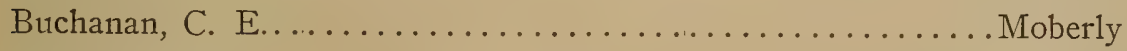

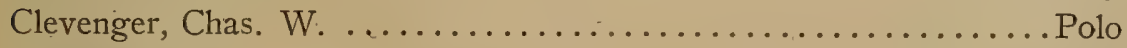

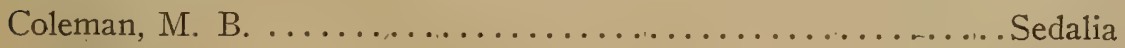

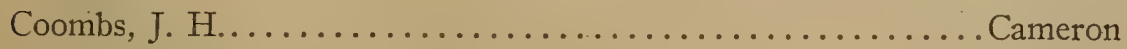

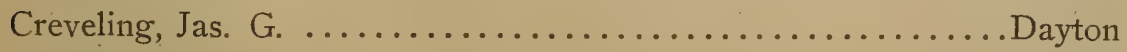

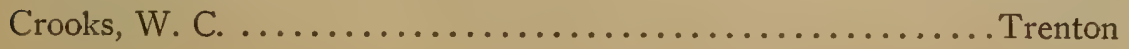




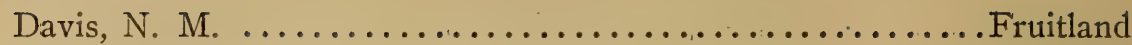

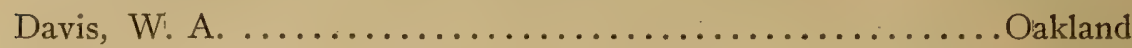

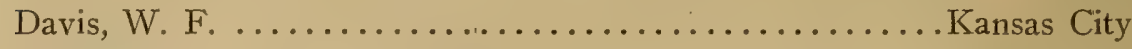

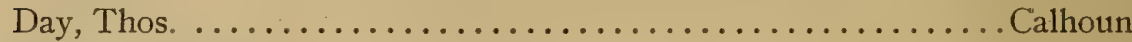

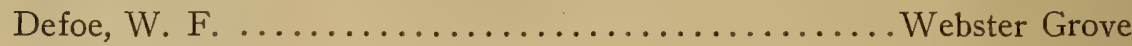

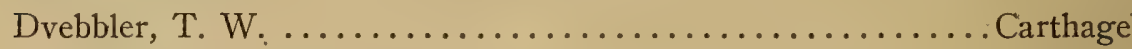

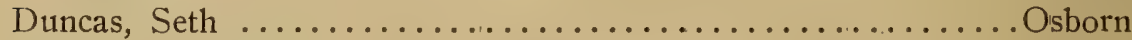

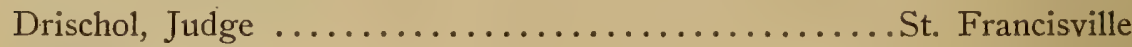

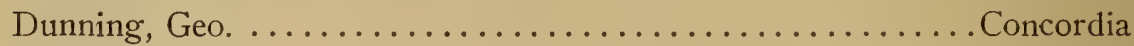

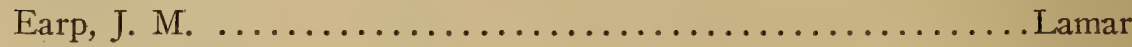

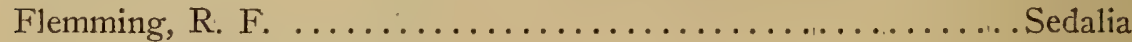

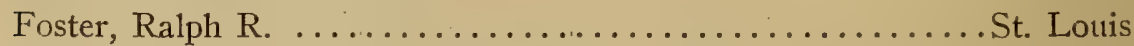

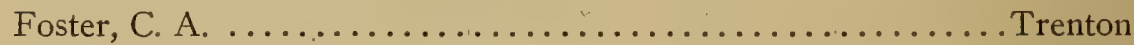

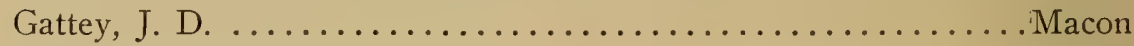

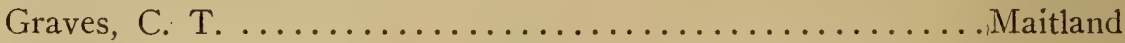

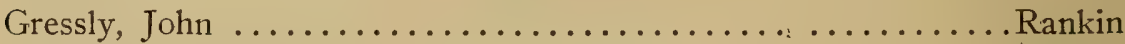

Grogg, S. F. . . . . . . . . . . . . . . . . . . . . . . . . . . . . . . . . . .

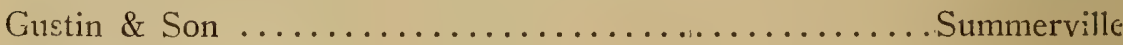

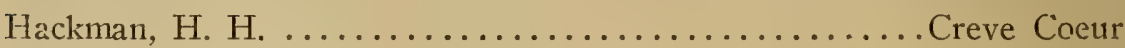

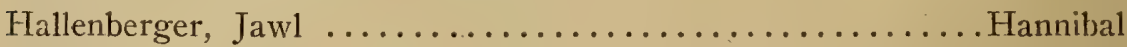

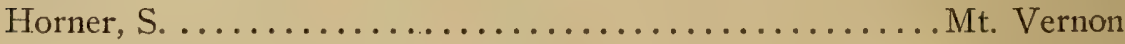

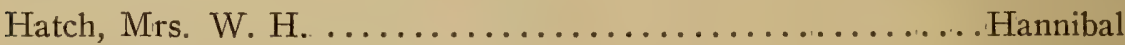

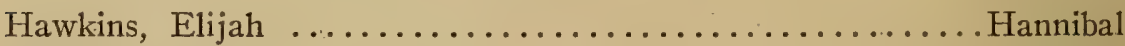

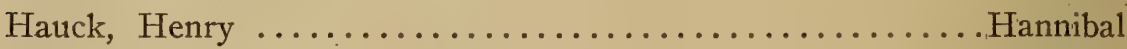

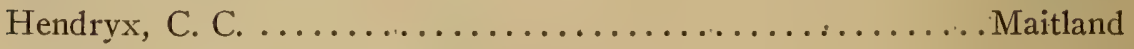

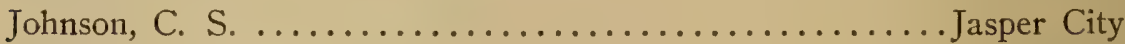

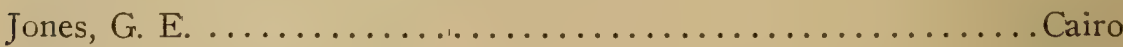

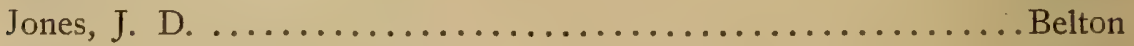

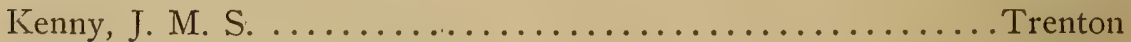

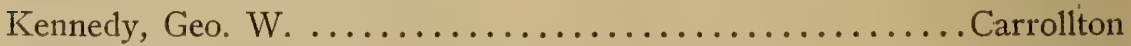

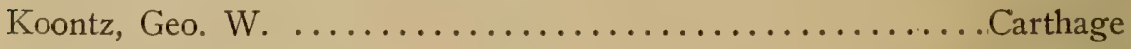

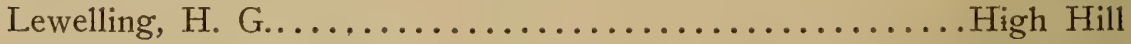

Linsey, $\mathrm{Wm} . \ldots \ldots \ldots \ldots \ldots \ldots \ldots \ldots \ldots \ldots \ldots \ldots \ldots \ldots \ldots \ldots$ Independence

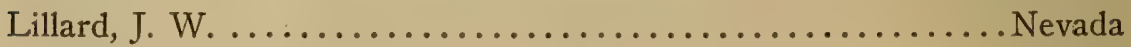

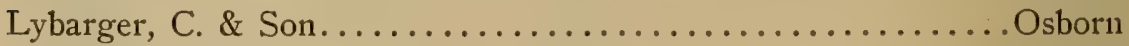

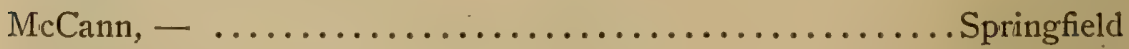

Medor, Judge B. B. ........................... Hornston

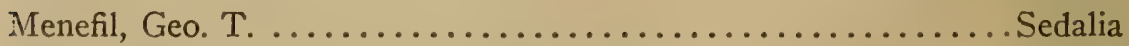

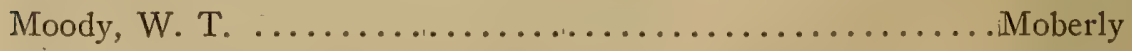

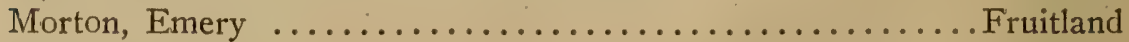

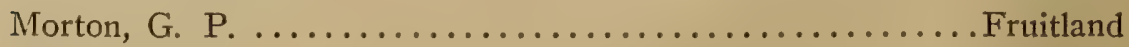

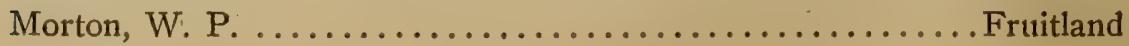


Mills, S. W. .Lancaster

Mills, John C. Lancaster

Null, Geo. W. Odessa

O'Briant, Everett Lancaster

Oliver, Rolla Dearborn

Parsons, H. R. \& Son Edina

Patterson, John Kirksville

Paulette, W. H. .Savannah

Paxton, F. M. Nevada

Perry, Dr. Geo. F. Albany

Piersol, J. L. Hannibal Roper, W. H. Sarcoxie

Rush, Lewis . Clark City Saffairans, Geo. W. .Palmyra

Settles \& Son .Palmyra Seymour, W. S. . .Palmyra Sharban Independence

Shattuck; L. E. Stanberry

Schindler, Clement Perryville

Shipley, E. R. Springfield

Shawan, Geo. H Lone Jack Shrader, J. M. St. Joseph Smith, Guy C Lamar

Smith, E. J. Cameron Snodgrass, Mary V. West Plains

Squier, Ralph R. Kansas City

Stephion \& Graham

Albany

Starkey, Birt .Big Piney

Still, Dr. Chas. Kirksville

Stibbins, G. W. . Carthage

Thompson, B. F. .LaBelle Tinsley, Walter Louisiana

Tripp, John R. Carrollton

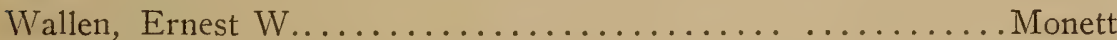

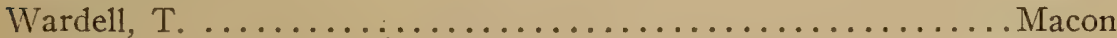

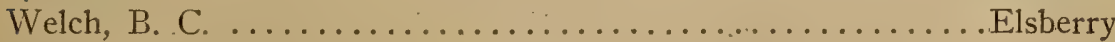

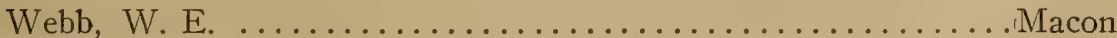

Winn, R. J. Palmyra

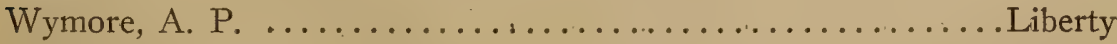
Young, Evan Lexington

Young, Robt. .St. Joseph

D C -4 
KERRY.

None in the State.

RED POLLS.

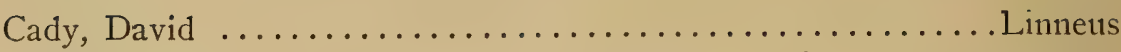

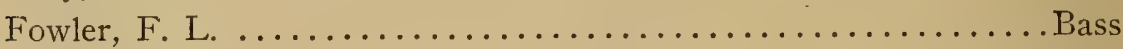

Haseltine, J. S. \& L. K. ..................... Dorchester

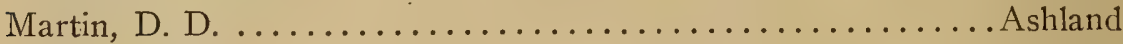

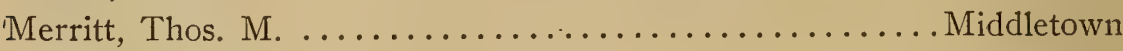

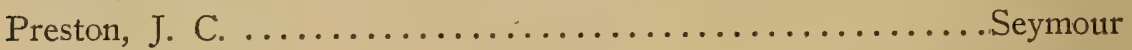

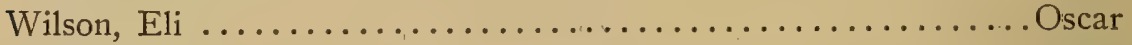

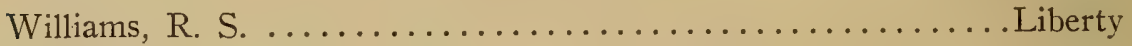

Wehrmann, Louis .....................................

\section{DISEASES OF DAIRY CATTLE.}

Any man who is in the dairy business should be familiar with the most important diseases of dairy cattle, and understand from the start how to prevent them. It is not possible to give details on the subject in this report, but it is well to call the attention of the dairymen to the fact that the most dangerous diseases of dairy cattle are tuberculosis and contagious abortion. There is liable to be some loss of young cattle from blackleg. There are other virulent contagious diseases which kill dairy cattle, but none of them are apt to attack the herds of this State, and are not, therefore, of so much importance.

Bulletins on tuberculosis and contagious abortion may be secured by writing Geo. B. Ellis, Secretary Board of Agriculture, Columbia, Missouri. The Federal Department of Agriculture at Washington, D. C., also furnishes valuable information on these subjects, which should be carefully read by every dairyman. These bulletins are free.

In breeding up the dairy herds of the State it will be but natural for their owners to improve them by the importation of well-bred cattle from other states. The most of the breeding stuff will likely be inported from the older dairy districts of other states, where the contagious cliseases are most prevalent. A careful reading of the bulletins of the State and Federal Departments of Agriculture will arm the dairymen with such information as will enable him to prevent the introduction of contagious diseases into his herd.

All the dairymen of the State should remember that they have access to the State Veterinary Service, and any time a dairyman finds him- 
self in need of veterinary advice he should feel free to write the "State Veterinarian," Columbia, Missouri, asking for whatever information he needs.

When breeding stock is purchased it should be with a tuberculosisfree clause in the contract. The State Veterinarian will, free of charge, make the test to determine whether the animal has the disease. 


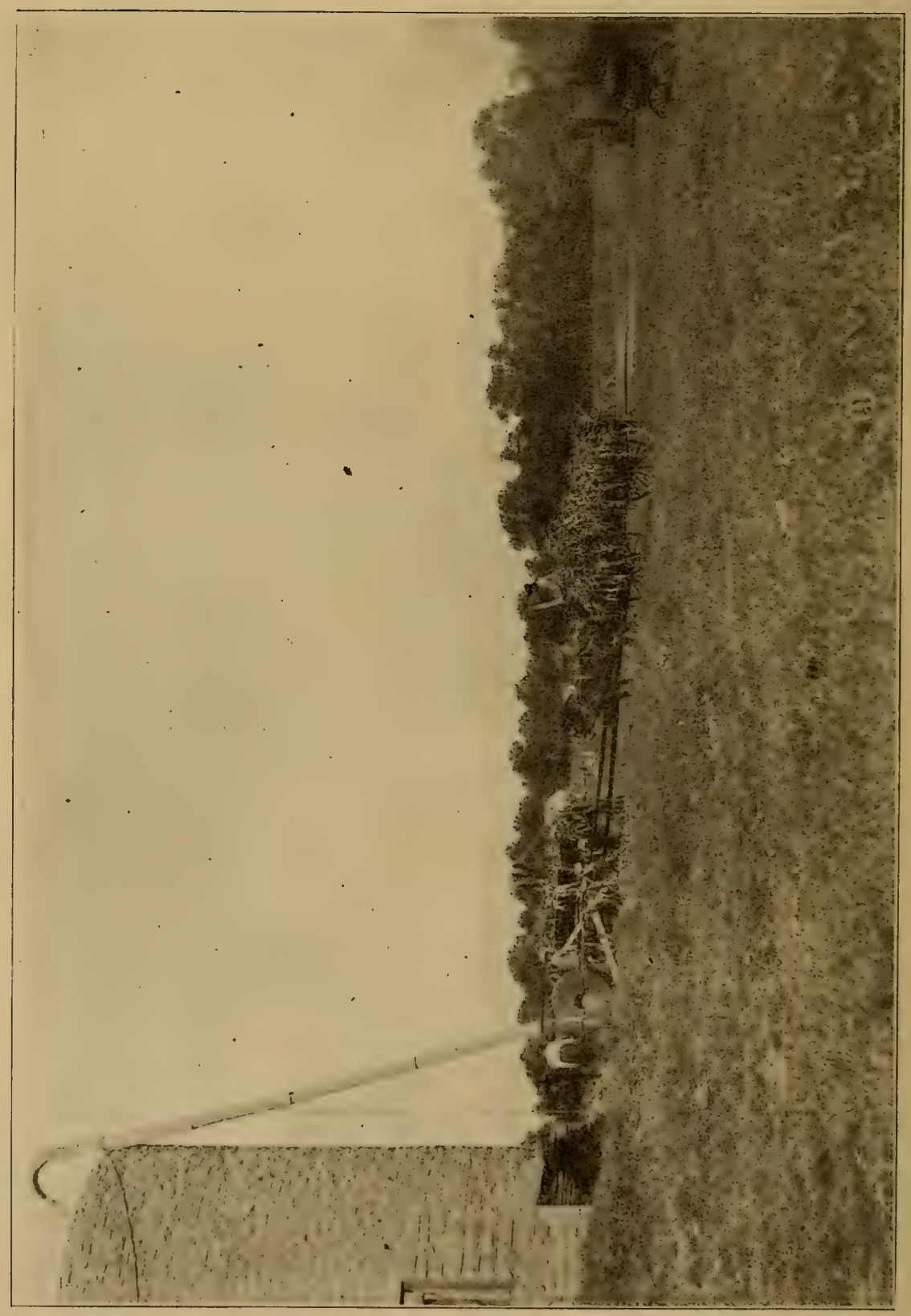

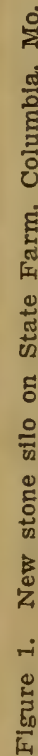




\section{THE SILO, ITS USES AND HOW TO BUILD IT.}

(By R. M. Washburn, State Dairy Oommissoner.)

It is not given that one man shall have all the useful experience. Every man of deeds has experiences peculiar to his work and valuable to all men in his line of work. Let us then add to our knowledge from the experience of our neighbor, respecting his experience as we would ask that he respect our soundly learned lessons. In these days of books and papers, one man's success or failure may prove a blessing to thousands. Let us, then, live in the present and improve our every opportunity to learn.

\section{ADVANTAGES OF THE SILO.}

I. Silage keeps young stock thrifty and growing all winter.

2. It produces fat beef more cheaply than does dry feed.

3. It enables cows to produce milk and butter more economically.

4. Silage is more conveniently handled than dry fodder.

5. The silo prevents waste of corn stalks, which contain about onethird the food value of the entire crop.

6. There are no aggravating corn stalks in the manure when silage is fed.

7. The silo will make palatable food of stuff that would not.otherwise be eaten.

8. It enables a larger number of animals to be maintained on a given number of acres.

9. It enables the farmer to preserve food which matures at a rainy time of the year, when drying would be next to impossible.

Io. In the south, where the rainy season destroys the exposed fodder, the silo will be found invaluable.

\section{HISTORY OF THE SILO.}

In Europe the silo has been known for hundreds of years. Ancient writers tell us of the practice of burying grain and green food in underground pits to preserve them from their enemies or against a poor year. These pits were ten to twelve feet deep, and often as wide, with Lottom and sides made tight by plastering with clay. All manner of green foods were preserved in these pits by pressing well and covering with 
earth. Foods thus treated would remain succulent and palatable for a year or more.

Probably because of the labor attached to this method it had almost ceased to be practiced, when M. Reihlen of Stuttgart, Germany, in the middle of the nineteenth century, revived the practice among his people. The greatest boom that the silo has probably ever had was started by a French farmer, Auguste Goffart, who, in 1877, published a little book, giving the result of his 25 years of experience and observation in the matter of ensiling green foods. In 1875 the Department of Agriculture at Washington began to investigate the matter and published its findings.

It is claimed that the first silo built in the United States was put up by Mr. F. Morris of Maryland in 1876. From that time on, the silo grew in favor with great rapidity. In England, in 1882, there were 6 silos; in 1884,600 ; in $1886,1,605$, and in $1887,2,694$. No later statistics are available. The English farmers, as a class, are more conservative than their American cousins; therefore, it is probably not un-

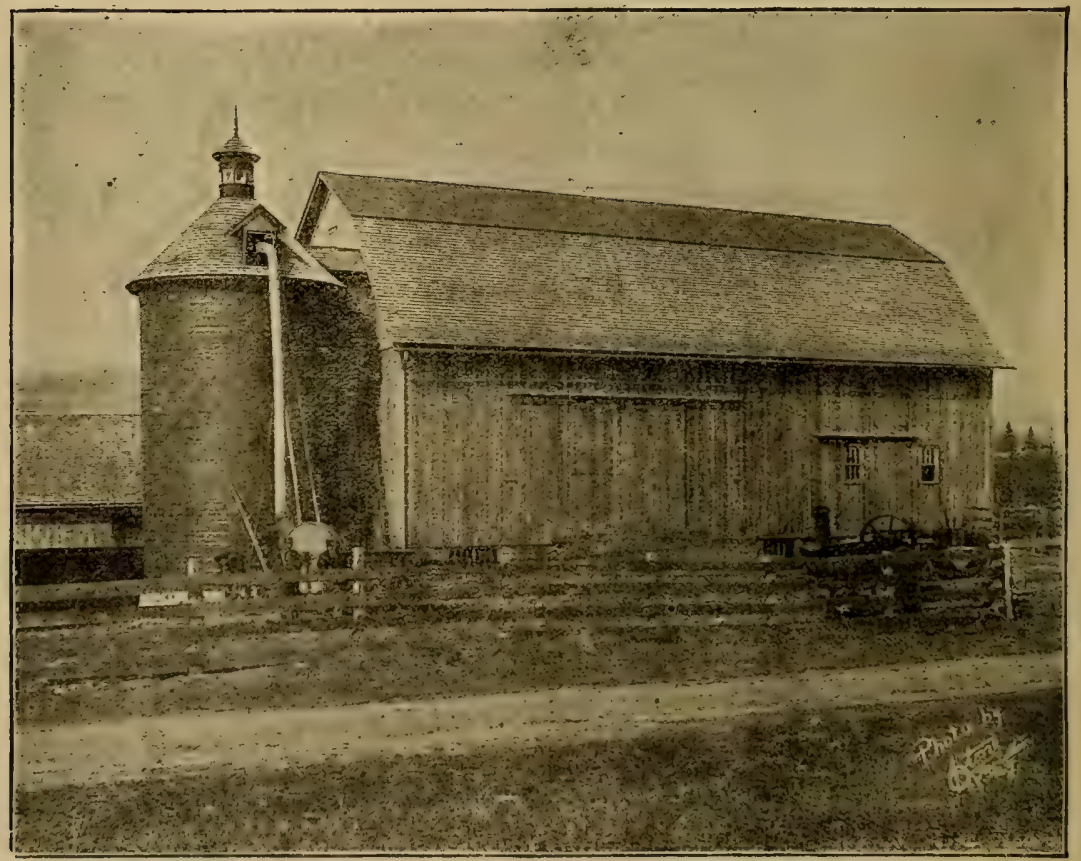

Figure 2. At the end of the barn is frequently the most convenient place for a silo. Note how close the cutter with blower stands to the silo.

(Courtesy Silver Mfg. Co.)

safe to say that the growth in number of silos in this country has been fully as rapid as in England. The increase in this country is probably 
more rapid now than at any previous time. This growth is a natural one, the result of true worth. The progress in the past has been interfered with to some extent by the extravagant claims of some overly enthusiastic writers. Now, that more is known of the silo, enough can be said without exaggerating. The silo in America will some day be as common as the cow stable.

\section{WHERE TO PLACE THE SILO.}

In former years the silo was placed inside the barn, but because of the odor that is constantly present with the silo it is now placed outside, but close, within two or three feet, to the side of the stable, best at the end of the main feeding alley. A door is cut through the wall at this point and the stable floor extended to fit against the silo. A cheap chute of boards is then built from the top of the silo to this extended floor. Silage thrown into this chute will drop into the basket or cart at the bottom, and will then be in the feeding alley, where wanted. When done feeding, the scatterings should be cleaned up and the door closed, to prevent a silage atmosphere in the stable. The outside silo usually has the advantage also of being easier to fill.

\section{FORM TO BUILD.}

At first silos were made square or rectangular, because easier of construction, but it was soon found that it was next to impossible to prevent the silage in the corners, and along the sides, from spoiling. It did not settle evenly or firmly. Some old silos made with corners have been improved by cutting off the corners with concrete. A form was made of bent wood, which was tacked to the walls each side of the corner, and concrete was slushed behind it. When this hardened the form was brought up to its width and the process continued. At this day there would be no excuse for building a silo with corners. A' cyclindrical silo causes no waste and will contain more silage for the amount of material used in building than a square one.

\section{SIZE TO BUILD.}

The larger the silo the cheaper it will be per ton capacity, but if too large for the number of stock to be fed, there will be a cntinual waste from decay. Silage exposed to the air, in warm weather, will spoil in 2 or 3 days, so stock will not eat it. When once the silo is opened it should be fed from continuously until empty. Build the silo small enough, so that the animals fed will consume a quantity of silage each day equal to a layer about two inches thick over the entire surface of the 
silage. Silage keeps better in a deep silo than in a shallow one, because more firmly packed. More feed can also be stored in a given space. Mr.

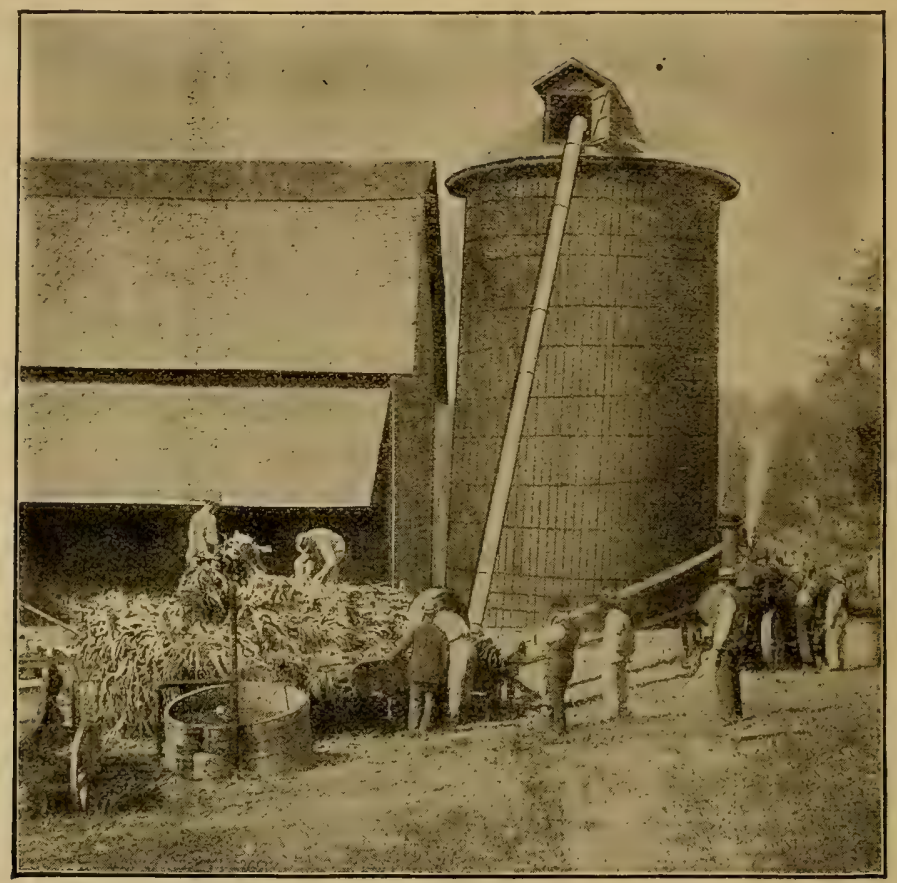

Figure 3. A stave silo being filled with the blower. (Courtesy Silver Mfg. Co.)

A. J. Glover, formerly of the Illinois Agricultural College, now with "Hoard's Dairyman," recommends the following:

\begin{tabular}{|c|c|c|c|c|}
\hline No. of animals to be fed from sllo for 200 days. & $\begin{array}{c}\text { Inside } \\
\text { diameter } \\
\text { feet. }\end{array}$ & $\begin{array}{c}\text { Helght } \\
\text { feet. }\end{array}$ & $\begin{array}{c}\text { No. acres } \\
\text { corn. }\end{array}$ & $\begin{array}{l}\text { A pproximate } \\
\text { capacity } \\
\text { in tons. }\end{array}$ \\
\hline 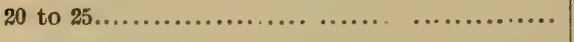 & 14 & 28 & 8 to 9 & 160 \\
\hline 25 to $30 . . \ldots \ldots \ldots \ldots \ldots \ldots \ldots \ldots \ldots \ldots \ldots \ldots \ldots$ & 15 & 30 & 9 to 10 & 115 \\
\hline 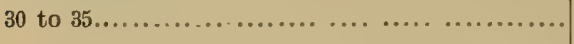 & 16 & 32 & 11 to 12 & 145 \\
\hline 35 to $40 \ldots \ldots \ldots \ldots \ldots \ldots \ldots \ldots \ldots \ldots \ldots \ldots \ldots \ldots \ldots \ldots$ & 17 & 34 & 12 to 14 & 175 \\
\hline 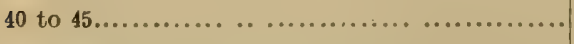 & 18 & 36 & 15 to 17 & 200 \\
\hline 50 to $60 \ldots \ldots \ldots \ldots \ldots \ldots \ldots \ldots \ldots \ldots \ldots \ldots \ldots \ldots \ldots \ldots \ldots \ldots \ldots$ & 10 & 38 & 18 to 20 & 250 \\
\hline 60 to $70 \ldots \ldots \ldots \ldots$ & 20 & 40 & 23 to 25 & 300 \\
\hline
\end{tabular}

"A silo should never be built over 20 feet in diameter. If it is necessary to have more material to feed it is better to build two small receptacles than one larger than 20 feet in diameter. It involves considerably more labor to handle silage in a very large structure than in 
one of reasonable size. Many farmers prefer to have two silos. They feed from one during the winter, and have tilc contents of the other for mid-summer's feeding."

\section{CONSTRUCTION OF SILOS.}

Essential Features.-It does not matter what material the silo is made of ; it must be air tight on sides and at bottom. Any crack or knot hole or poor joint at the door will admit air, and the silage will rot just in proportion to the amount of air that enters. The receptacle must be strong enough to withstand the lateral pressure of the silage when it settles. This lateral pressure at io feet from the top is IIO pounds per square foot, at 20 feet 220 pounds, and at 30 feet, 330 pounds, and at 40 feet, 440 pounds. It is very difficult to make deep rectangular silos whose walls will not spring enough to allow air to circulate up and down the sides and cause losses.

Depth of the Silo.-This should be made as great as practical, because, Ist, in this way the largest amount of food per cubic foot of space may be stored; and, 2nd, the silage keeps better because packed so solid; and, $3^{\mathrm{rd}}$, there is less relative loss at the surface. The top of the silage always spoils to a depth of 2 to 8 inches. No silo should be less than 25 feet deep. A silo $20 \times 40$ will hold twice as much as one $20 \times 25$, and one 36 feet deep will hold 5 times as much as one 12 feet deep.

Summer silos should be deeper in proportion than those intended for winter use, because the silage spoils faster in summer and must be fed down at the rate of about three inches a day to have always fresh silage.

Foundation.-This must start on level, firm earth, and should extend about 2 feet above the surface of the ground. If the foundation is started deep the hole should be dug large enough to give ample room outside of the wall to thoroughly tamp the earth up close to the foundation. There is a tremendous outward pressure against this wall, especially in deep silos, and if it is not made strong it will crack and admit air. It is also well to build into the wall, about 18 inches above the surface of the ground, several heavy wires to keep the wall from cracking. It should be made of stone or brick, laid in cement mortar, or of concrete, and from 12 to 18 inches thick, depending on the height the silo is to extend above it.

Placed Partly in Ground.-It is a good plan to dig down 4 or 5 feet in order to secure good, firm earth on which to start the foundation, and also in order to get the greatest capacity in the silo without 
going too high into the air. Deeper than five feet would not be either convenient or safe.

Drainage.-Care must be taken in wet places not to dig down much, or else the soil must ba drained. In many places even a good wall of stone, laid in cement, and well plastered inside with cement, will not keep the soil water out. In some parts of the south the houses can have no cellars on this account.

Protection Against Frost.-It does not injure silage to freeze. Even if the heat of the silage itself should not prevent the portion close to the wall from freezing, that portion may be piled up by itself on the silage and fed as soon as it does thaw out.

Floor.-On sandy soil a floor will be needed to keep out soil air, but on clay land there need be no floor unless rats and mice trouble, then a cement floor may be laid.

Roof.-In the southern portion of this State and south no roof is needed. Farther north, where a snow fall may be counted on a cheap roof will be found convenient, not that the snow would injure the silage, but that it would mix with it and be in the way when fed.

Painting of Wood Silos.-A coat of paint or tar on the inside of a wood silo does not prevent the silage juice getting into the wood, but does retard it drying out when the silo is empty, and thus hastens decay. The outside may be painted and the inside washed with a wood preservative, something that will not hold the water and will destroy the mould plant in the wood.

Cement Work.-Every farmer who makes farm conveniences, such as stable floors, fence posts, silos, etc, of cement (and this should include practically all farmers) should send to the United States Department of Agriculture, Washington, D. C., and ask for farmers' bulletin No. 235, on "Cement Mortar and Concrete, Preparation and Use for Farm Purposes." It gives in plain language the kind of material, proportions to use, and how to proceed to make everything needed in cement on the farm.

THE KIND OF SILO TO BUILD.

This will depend very much on the cost of lumber, stonc, sand and gravel in the particular neighborhood and on the farmers' ability to build permanently, even though it does cost somewhat more at the start.

On a permanent stock farm, where the farmer has means to build well, there is no doubt that the stone, concrete or cement block silo would prove the most economical, but where there is limited means, and on farms that are rented for a short term of years, the all-wood stave or the wood frame cement lined silo would be more profitable. 


\section{STONE SILO.}

When stone is cheap and a long-lived silo the object, the stone silo may be the most economical.

That portion of the stone work which lies below the surface of the earth should be laid in cement rather than lime mortar. Lime sets very slowly under ground. "After the wall is 2 feet above ground a good lime mortar may be used, but in this case there ought to be at least two months for the wall to season and set before filling."
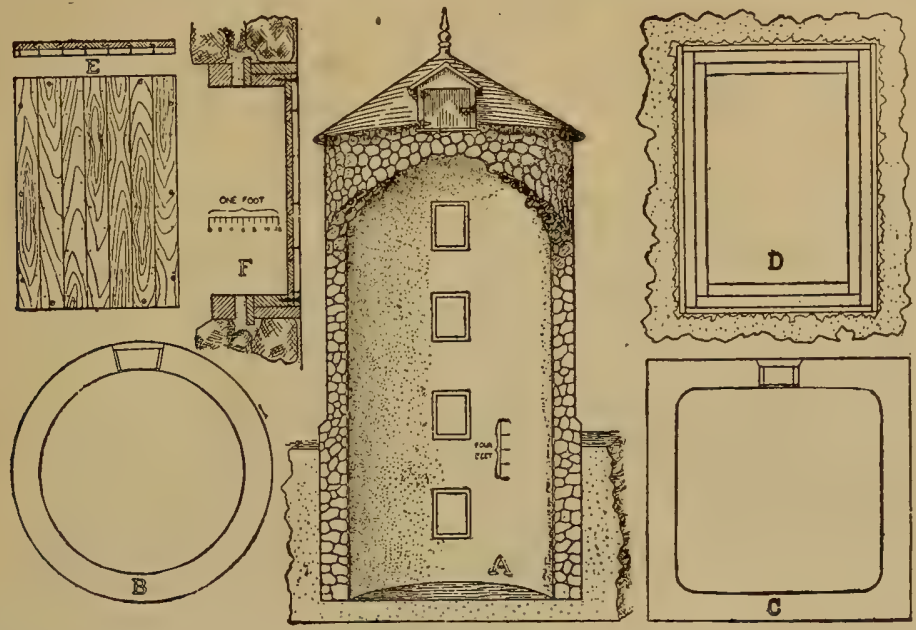

Figure 4. Shows construction of stone silo. The basement "A" is a little too deep for any but bank barns. "B" shows a cross-section of the silo. " $C$ " and "D" the door way. " $E$ ". the door in side view and end view. " $F$ " the door in place.

(After King.)

The wall at the bottom should be 18 inches in thickness and at top 12 or ten inches, the narrowing being made on the outside, the diameter inside being kept the same all the way up. See figure 4 .

The Missouri Experiment Station built a stone silo in the summer of 1905. It is 20 feet in diameter and 40 feet high, holds about 275 tons. The wall is 18 inches in thickness, laid up in lime mortar. Above and below the five openings in the silo one-half inch iron rods are built into the wall in the form of hoops to keep it from springing or cracking. The inside is plastered smooth with Portland cement mortar. For the construction of this silo there were required, approximately, I20 perch of stone. The average cost of labor in construction was $\$ 3.50$ a perch. The first cost seems great, but with an occasional whitewashing with cement inside to fill the small checks, it ought to last a hundred years. This is the silo referred to as having had no roof during the fall rains. See figure $\mathrm{I}$. 
The Doors.-Doors for feeding should be arranged as in figure 4 . The door frames should be made of $4 \times 6$ stuff, matched together at corners. A Ix4 board may be firmly nailed on the inside of this frame to form a jamb for the door to fit against. To make the door fit air tight, tack felt on the edge of this jamb. Arrange to have the door flush with inside wall of the silo and have stones projecting into the doorway enough to hold the pressure of the silage against the door. Make the $4 \times 6$ door frames 20 by 30 inches inside, then me he the door of two thichnesses of matched flooring, running in opposite directions and all screwed firmly together and to two firm Ix4 cross pieces, which are on the outside. Through the icenter of the door, projecting outward, put a $5 / 8$ bolt, Io inches long. This should have a large washer on the inside. This bolt is to put through a $3 \times 4$ cross piece to draw the door up snug to the jamb. The silage above will not press it snug enough and it is unwise to nail it. This makes an exceptionally good structure, though one of rather great first cost.

CEMENT BLOCK SILO.

Cement is getting to take the place of stone in most lines of construction. There are a few cement block silos in this State. Mr. J. O. Bailey, Kirksville, Adair county, Mo., has one 16 by 32 feet, of which he says:

"I made the blocks myself-size 8 by 8 by 24 inches, curved enough so that 25 of them would lay a complete circle, I6 feet in diameter in the clear. Proportioned the cement and sand I to $5, i$.e., I part cement to 5 parts sand. It took about 50 yards of sand and 205 sacks of cement. I also laid a No. 9 wire between each layer of blocks up twenty feet. I don't think now it is really necessary to use the wire.

"I had a mason to superintend making of the blocks, but any onc with average intelligence can make the blocks as good as a mason. The main thing is to get sand and cement thoroughly mixcd. It does not want to be too wet, just moist enough to pack good in the mold. After the blocks have been made half a day or so they should be wet every day; this keeps them from drying too fast and from cracking.

"I hired a mason to lay up the blocks; this is the only skillful worl: about it, they have got to be laid up true. I did not cement inside of silo. My silage spoiled some around the outside. This is due to lack of moisture in the silage and also in the wall. I should lave wet the sliage and wall as the silo was filled, but was not fixed to do this.

"My silo is built $3 \frac{1}{2}$ feet below the surface and in the last 4 or 5 feet of silage there was not a forkful spoiled. 
"Two men can make 90 to Ioo blocks a day after they become accustomed to it. I used a wood mold which any carpenter can make and will not cost over $\$ \mathrm{I}$ or $\$ \mathrm{I} .50$, at most.

"Now as to the doors. I used $2 \times 6$ plank for the jambs and set them flush with the outside of the wall; as the blocks are 8 inches thick there are two inches on inside for door to set in. The doors are ship-lap doubled with a good quality of tar paper in between, also a layer of tar paper on the side that sets against the jamb. The doors are 2 feet square and every 4 feet. Total cost about $\$ 225.00$. The cost for labor to fill it I estimate at $\$ 50.00 . "$

This is a cost of nearly $\$ 2.00$ per ton capacity, but inasmuch as it will last a great many years it may be the cheapest kind in the long rum. See figures 5 and 6 for block silo and form of a block.

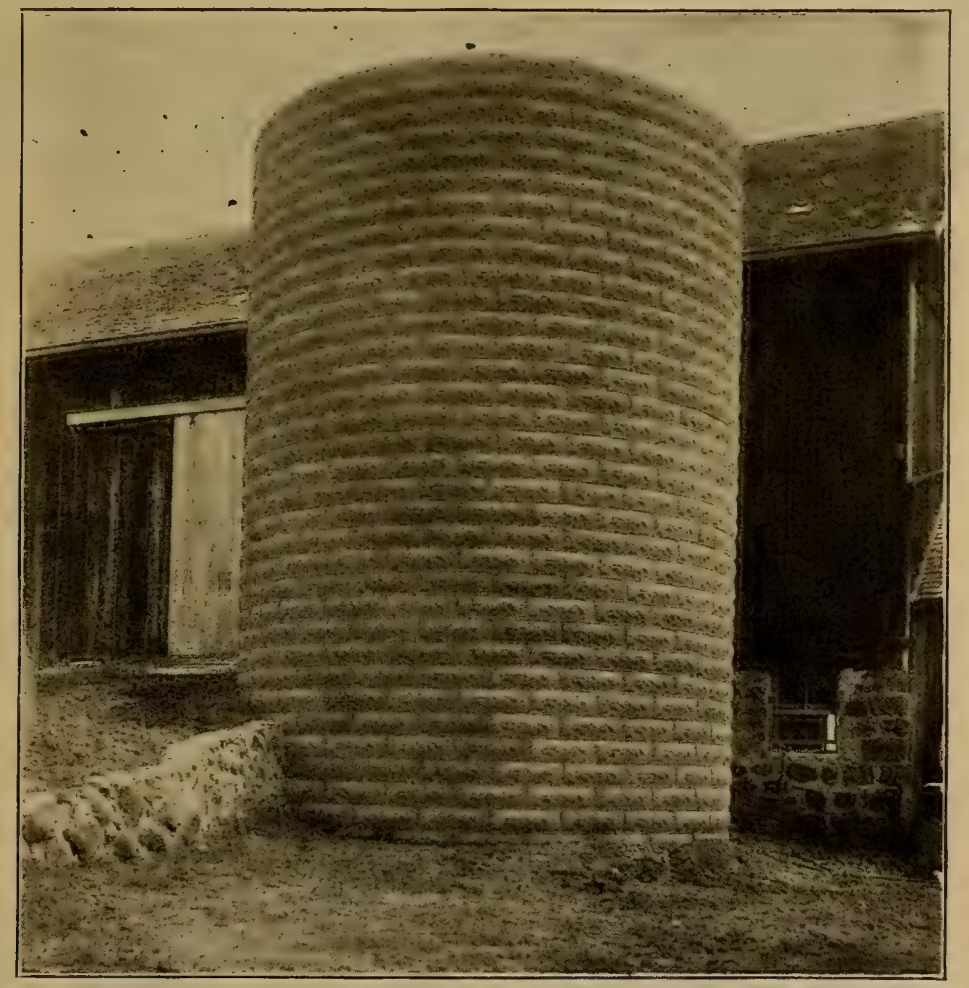

Figure 5. Cement block silo. The kind built by Mr. Dunlap of Center, Ralls county. (Courtesy Hoard's Dairyman.)

Mr. Alfred S. Dunlap, Centre, Ralls county, Mo., has a cement block silo 16 by 32 feet inside, extends 18 inches in the ground. $\mathrm{He}$ says, "The blocks are $6 \times 6$ inches by 2 feet long. Used 200 sacks of Portland or Atlas Brand cement in the foundation and blocks. I,400 
blocks were required to build it. Just what the cost was I do not know, as my farm help worked at making the blocks, commencing in the spring and working at odd times. It, perhaps, cost $\$ 275.00$, but I did not haul my sand and gravel more than a Ioo rods. I used a No. 14 cutter and a ro horse-power traction engine, and did the work of cutting to my entire satisfaction. We worked three days and filled it about

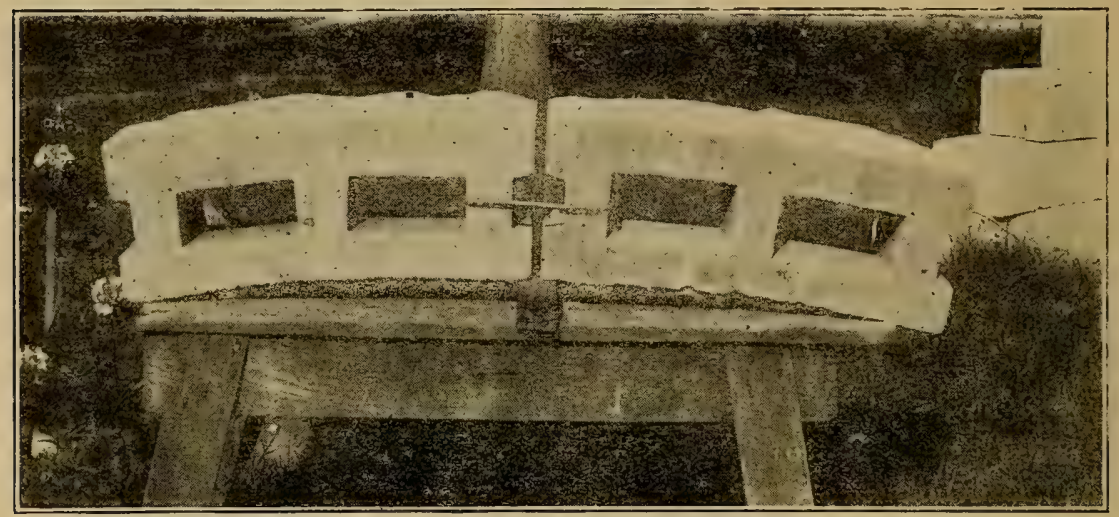

Figure 6. Form of block used in the silo. Note the manner of reinforcing the blocks by means of $3 / 8$ iron binders. The hollow blocks require less material than the solld ones, and will not freeze so readily.

(Courtesy Hoard's Dairyman.)

two-thirds full, and filled with corn grown on bottom land and very heavy."

Mr. Dunlap here touches a very important point. He got his material in the spring and had his men work at block making when they could do little else, thus saving much valuable time. Mr. Dunlap also mentions having a loss of silage close to the wall because, as he say's, he did not cement up the inside after the blocks were laid up. The inside should be well cemented to close all pores possible, then, when the fodcler is cut in, water in plenty should be used, especially around the edges next to the walls.

\section{CONCRETE SILO.}

Silos are getting to be made of concrete, slushed and tamped into a solid structure by means of forms. The only one in this State known to the writer is that of Mr. C. J. W. Jones, Roanoke, Howard county, Mo. This silo was built in the summer of 1905 . It is 16 by 40 feet inside measurement, it being 9 feet in the ground. He first dug the hole and leveled the bottom. Then started the inside form, which was made of old pieces of fence boards, stood on end around the circle and held in place by thin limber boards tacked onto them. He also had a center 
pole to guide by and brace to. The bottom wall was made thick ano tamped against the earth bank. When the level of the ground was reached he carefully leveled up the work and started the outside form, which was made of a band of iron, 20 inches wide and 53.43 feet long, rolled to form the circle and was fastened with clamps at the ends. The silo being 16 feet in diameter and the walls 6 inches thick, the form is then $\mathrm{I}_{7}$ feet in diameter. This was leveled and the space betwecn it and the inner wall of boards filled with concrete and tamped. When this hardened the form was loosened, raised and screwed tight again after getting it level; the space again filled and so on to the top. The inner wall was raised as needed, being braced against the center pole from all sides.

See figure 7. Notice at the top of the silo the iron form still stands surrounding the wall it last built.

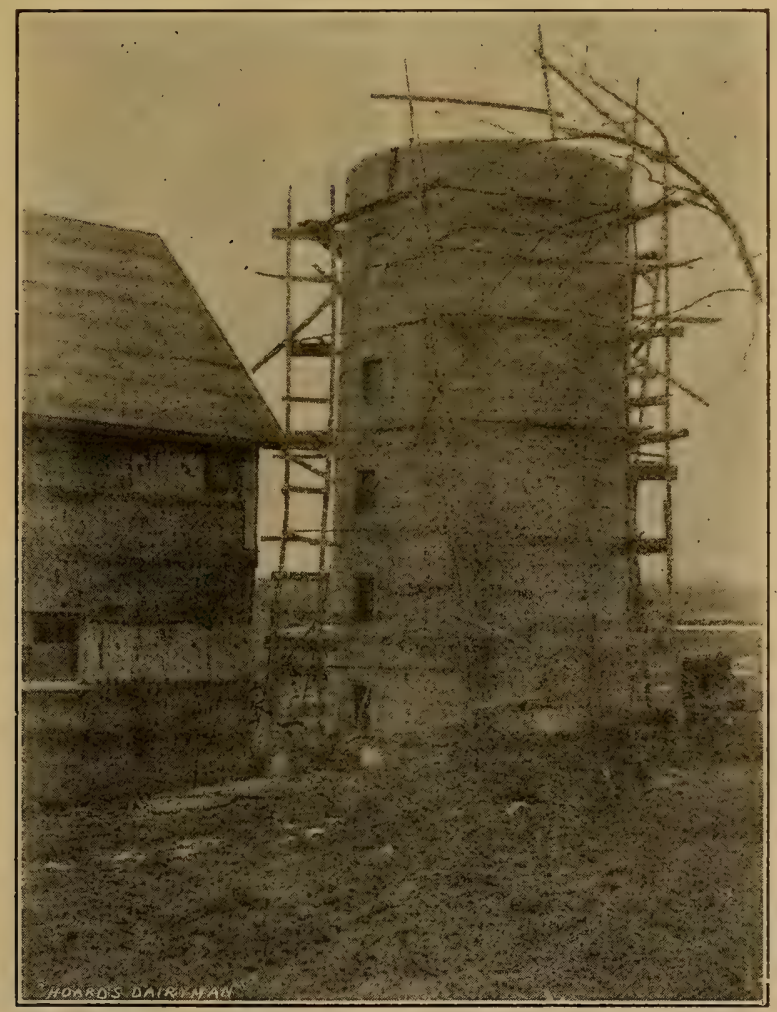

Figure 7. Concrete silo of Mr. C. J. W. Jones, Roanoke, Mo. Made by Mr. Jones and his son:

(Courtesy Hoard's Dairýman.)

Every few feet a wire rope made of four strands of No. 9 wire, twisted, was built into the wall to prevent cracking. Iron rods, bent to 
the circle with hooks on the end, as shown in figure 8 are sometimes used in concrete and stone walls.

To build this there was required about 40 cubic yards broken stcne, 20 of sand and 50 barrels of cement. Mr. Jones and his son did the work when they could steal the time from farm work. It would be difficult to say how much time was used in the making, but there is one thing sure, there is a silo that will not dry up and open cracks, nor blow down with anything less than a cyclone, and will douttless last two or three generations. Material cost about \$150.00. Doors were made by building the frames into the wall while making. The frames are of $2 \times 6$ stuff, made and set same as described under stone silo.

Roof.-No roof is provided; nor by Mr. Jones deemed necessary. It is only a convenience in bad weather.

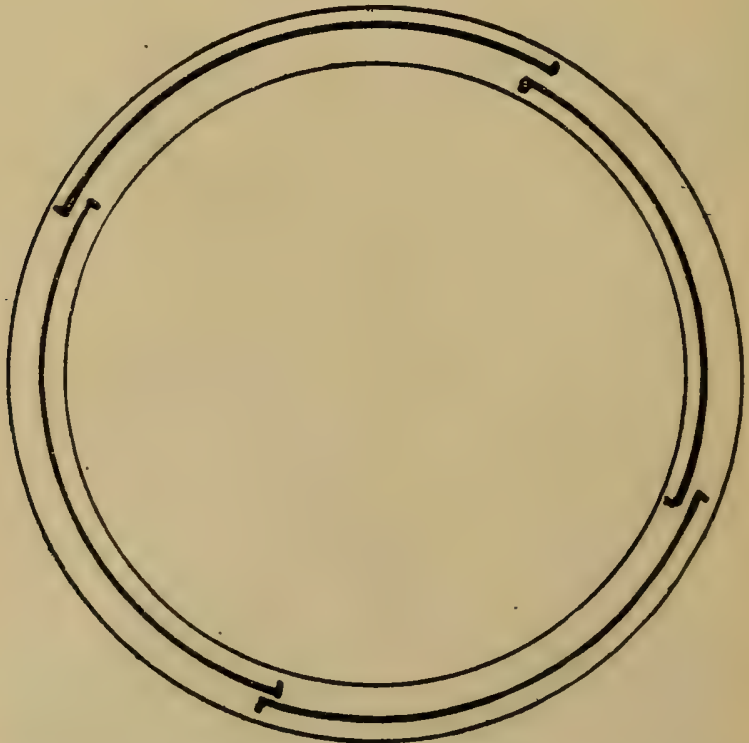

Figure 8. Showing manner of putting iron rods turned at the ends into stone, brick or cement foundation. The heavy lines inside are the iron hoops.

(After King.)

CEMENT LINED SILO.

This is a modification of the old all-wood silo, and is known as the Gurler silo, because Mr. Gurler of Illinois brought it into prominence.

Material Needed.-For a silo of this kind, I4 by 28 feet, (about 90 tons if filled full), there will be needed, for the foundation, if 12 inches thick and 3 feet high (one foot below ground and two above), 500 brick and 650 pounds cement and two-third yards of sand; 
or 6 perch of stone and 450 pounds of cement and $1 / 2$ yards sand; or 3 yards gravel or crushed rock and 1,500 pounds of cement and one and two-third yards of sand. Mix the cement mortar I part cement to 3 parts sand; for concrete use I cement, 3 sand and 6 gravel or crushed rock-the crushed rock is stronger than the gravel. Imbed in the wall a rope made of 4 strands of No. 9 wire, twisted, or, if more convenient, two or three circles of old barb wire. This would go well in the concrete wall. For the plaster there will be needed about 5,000 pounds cement and 4 yards of clean sand. The plaster is put on about half an inch thick.

For the superstructure, not including the roof, there will be needed 55 pieces, $2 \times 4$, I 4 feet long, and 44 pieces 16 feet long. These are for studs, sill and plate. For sheeting, one-half inch thick and 4 inches

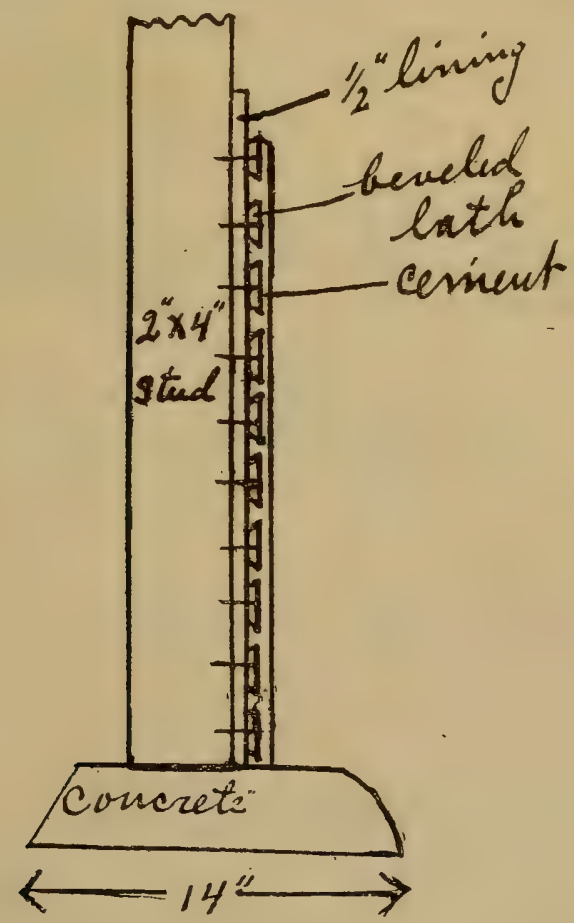

Figure 9. A cut showing construction of the cement-lined silo. Onto the $2 \times 4$ stud is nailed the half-inch lining, and onto that the beveled lath, then the whole thing is plastered with cement mortar.

wide, about $\mathrm{I}, 600$ feet unmatched. Lath needed, 52 bundles plain house lath or its equivalent of beveled lath made of 3 -inch batting, ripped and corners on one side taken off. The University of Illinois reports excellent success with common house lath nailed flat against the sheeting 
without any furring. It is still considered better to use the beveled. See figure 9. About I50 pounds of nails will be needed. For the four doors about 34 feet of matched flooring.

To Build.-On top of foundation made level place $2 \times 4$ s cut two feet long to form sill. Bed them in cement. Upon this sill stand $2 \times 4$ studs, I foot apart, a 16 -foot and a I4-foot lapped two feet and well spiked. Toe-nail these to the sill and brace well to keep perfectly plumb. Sheet up to the bottom of the first door, about two feet, put in the door frame made same as described for stone silo except of $2 x_{4}$ stuff. Continue sheeting up to next door and again put in the frame. Continue to the top, always fitting the sheeting well up to the frames and nailing snug to the studs. Now put on the plate made of $2 \times 4$ stuif cut two feet long and spiked on top of the studs. Put on a second layer of these pieces, breaking joints with the first. Onto this sheeting nail the lath securely and horizontally and plaster the whole wall about half an inch thick with cement mortar. The foundation wall, both inside and outside, should be beveled to run the water away from the wood portion.

Hoops.-At two feet, six feet and ten feet from the foundation it would be wise to put hoops made of the half inch sheeting stuff nailed firmly to the studs around the silo. The lower one would best be made three thicknesses; the others, two.

A roof may or may not be put on. The outside may be covered, but there will be no loss of either quality or quantity of silage if it is not Sheet iron painted on both sides makes a very good cover, though stove pipe iron is cheaper.

The dairy department of the Missouri Experiment Station built a silo of this kind in the summer of 1904. The work was done by the farm and stable hands at odd times. It would be difficult to say how much the work cost. The material cost about \$150.00, including the shingled roof and the stove pipe iron covering. There should be an open space at bottom and at top of this outer covering to allow a circulation of air to prevent the wood from rotting. Freezing will not injure the cement lining, but if the silo is not protected the wind may spring it enough to crack the cement a little, making it best to whitewash with a cement wash occasionally. Mr. H. B. Gurler of DeKalb, Illinois, has six silos of this make, three of which have been in use for 9 years and are still in excellent condition.

\section{WOOD-LINED SILO.}

This silo is built like the previous one, except that in place of the lath and plaster, tar paper and a second sheeting of half inch boards 
(this time matched and smooth inside) are used. This makes a very good silo as long as it lasts, but the wood cannot dry readily between these layers, rot sets in and in a few years a new lining is needed. This kind was built largely some years ago, but is not to be recommended

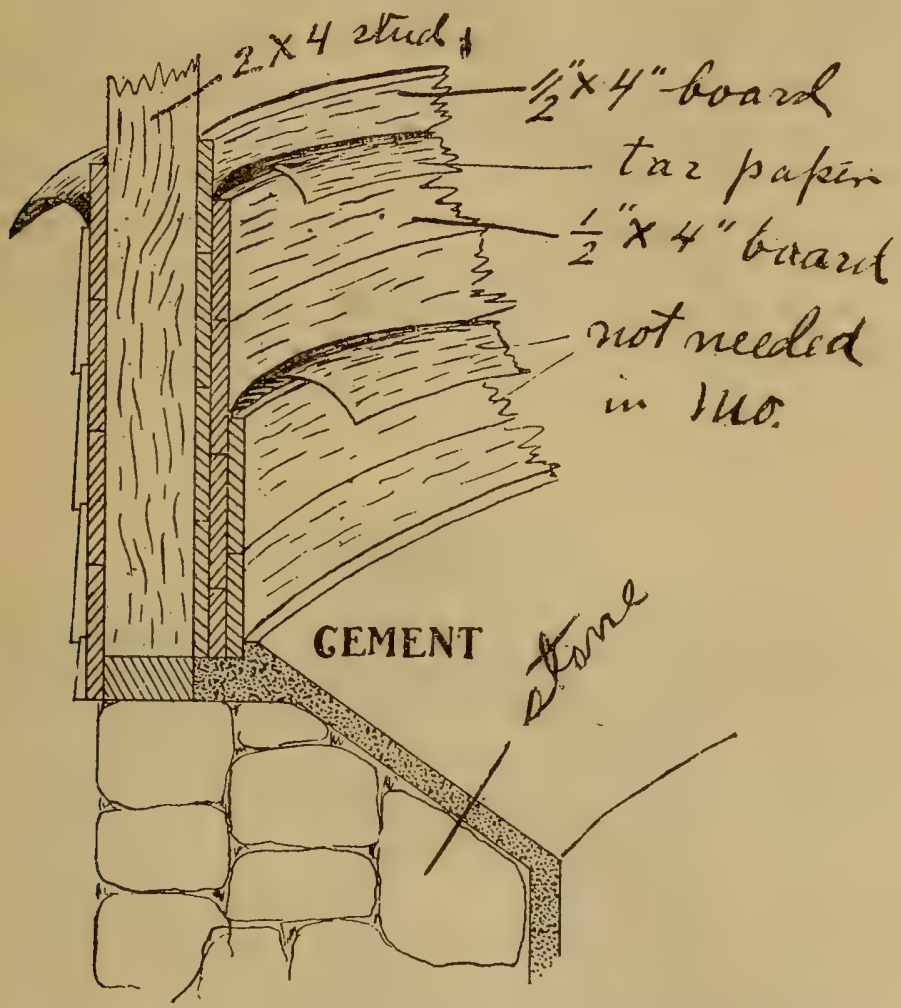

Figure 10. Wood-lined silo. The second paper and the third sheeting are not needed in Missouri. The outer covering is good, but rather too expensive.

(After King.)

on account of its short life, unless the silo is to be built under peculiar local conditions. Fig. No. Io shows method of placing sheeting and paper The inside layer of boards and the second layer of paper are not needed in Missouri, neither is the outside boarding essential.

Mr. H. C. Goodrich, Calhoun, Henry county, Mo., and Mr. James Elliot, Windsor, Henry county, Mo., have silos made in this manner. They report good silage and satisfaction thus far, but in Io or 12 years from time of building a new lining will likely be required.

\section{STAVE SILOS. (READY MADE.)}

The demand for silos is so great that there are now on the market several makes of ready-made stave silos. These are merely immense, 
straight-sided barrels, well hooped to hold the pressure. These being of single thickness, dry out well and will last much longer than the double-layer home-made kind. These ready-made silos may cost somewhat more (first cost) than one of equal size built at home, but the writer has found them to be very satisfactory on account of the fact that all joints fit so well that there is practically no waste from spoiling. The silo, though cheap at first, that is not tight and causes a continual loss of 3 or 5 per cent of the silage made, may, after all, be expensive. These come knocked down, with full directions as to how to proceed to set them up. It is always well to follow the advice of the manufacturer in such matters. Prices can be gotten from the dealers on request.

Mr. Jesse Williams, Excelsior Springs, Clay county, Mo., has a ready-made silo, of which he says: "The *** silo, $16 \times 30$ feet,

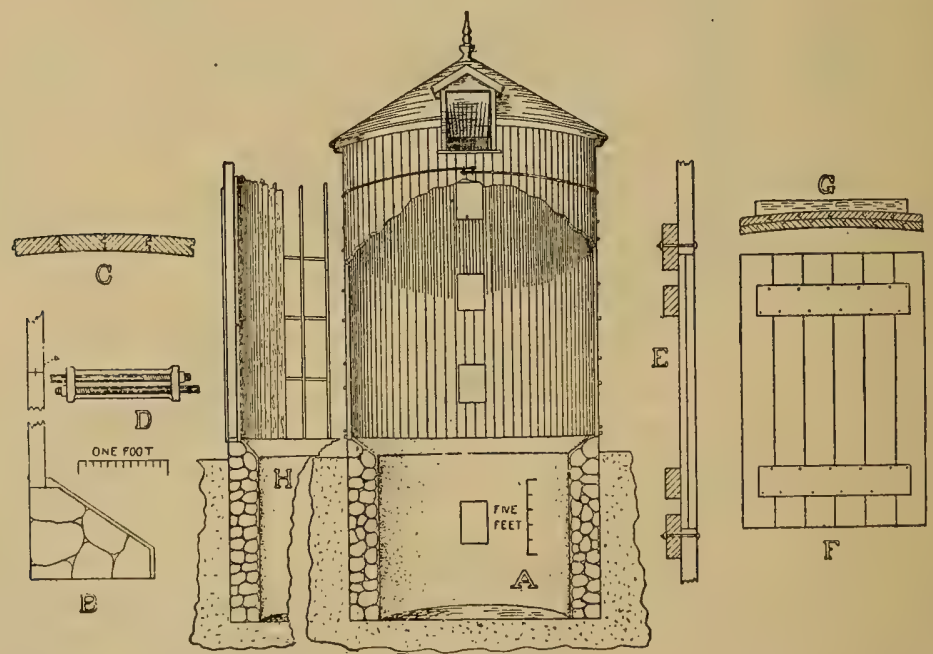

Figure 11. Stave silo, showing construction. "A," deep basement; "B," stone foundation top, showing silo set flush with outside of the wall; "C," cross-section of 4 staves, showing tongue and groove; "E," dool fitted in place; "F," the door; " $G$," cross-section of the door.

(After King.)

with six-foot concrete basement, is entirely satisfactory in construction. We put in about 20 acres of corn, which kept perfectly. We have fed about 45 head, ten calves, and the rest grown stock, for two and onehalf months, and have fed about one-third of the ensilage. The **** ensilage cutter which I purchased at the same time is also satisfactory. We tried it to its full capacity and it never choked."

Mr. Fritz Sensor, Corder, Mo., has one of these stave silos, and is pleased with it. 
STAVE SILO (HOME MADE).

This "Buff Jersey" silo is becoming popular because of its low, first cost, solidity when up, ease of construction and length of life. While it will not last like stone or cement, it will last until it has paid for itself many times over.

Foundation.-Make the foundation same as for the cement-lined or the ready-made stave, except make the sill of 2 by 6 stuff instead of 2 by 4 .

Material.-For a silo I 4 by 28 feet, plain straight pine 2 by 4 , free from knots and wain edges needed, I 32 pieces I 2 feet long, I 32 pieces 16 feet long and 4 pieces of 4 by 6,28 feet long, 40 pieces five-eights round iron, I2 feet long, with threads cut a foot on each end. Each rod should be supplied with 2 large washers and 2 nuts. Nails and 6-inch spikes in plenty.

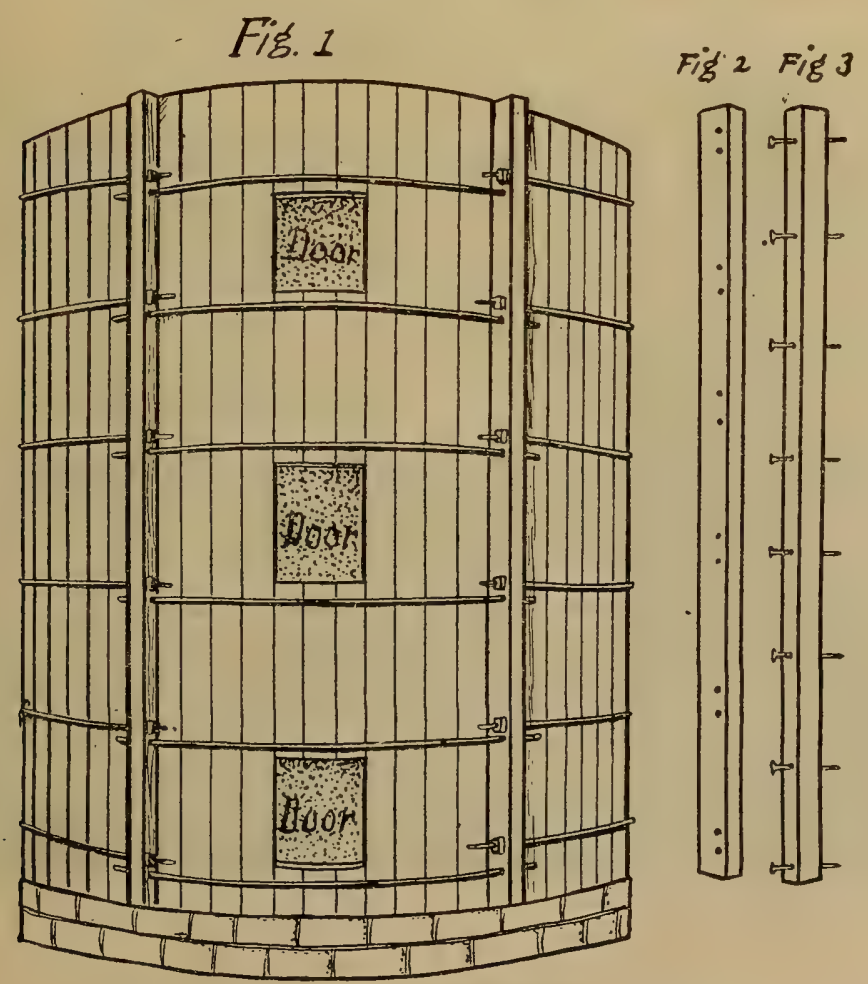

Figure 12. Figure 1 shows Buff Jersey silo complete. The method of placing doors Is shown, and also the hoops and the way they pass through the $4 \times 6$-inch timber elsewhere described. Figure 2 shows one of these $4 \times 6$-inch pieces with holes bored ready to be placed in position. Figure 3 shows one of the $2 \times 4$ pieces with spikes passing through it as they do in constructing the walls. Some parties have reported that they have built their silos with the 2x4's flatway, making walls four inches thick. They used 12d nails. 
The 4 by 6 are to form the "corners" of the round silo and also act as lugs for the hoops to go through and draw against, as shown in figure I2. Bore holes through these posts through their 6-inch dimension, starting close to one edge and ranging outward almost cornerwise through the stick. Beginning close to the bottom of the silo, make these hoop holes the following distances apart: from Ist to 2nd, 2 feet; 2nd to $3 \mathrm{rd}, 2$ feet; 3 rd to $4^{\text {th }}$ and 4 th to 5 th, each 3 feet; and the next five each 4 feet apart. The 2 by 4 do not need planing, but care must be taken to get straight pieces and clear. Southern pine is excellent for this work.

To Set Up.-First set up the 4 posts, brace well, plumb, and tocnail to the sill. Make sure each is equidistant from the center of the silo to be, or in other words, in a circle. Put in the lower hoops and start the nuts, then stand a 2 by 4 inside these hoops, spike it soundly to the post, using a six-inch spike and driving straight through the 2 by 4 edgewise, set up another and do the same by that to the first stave.

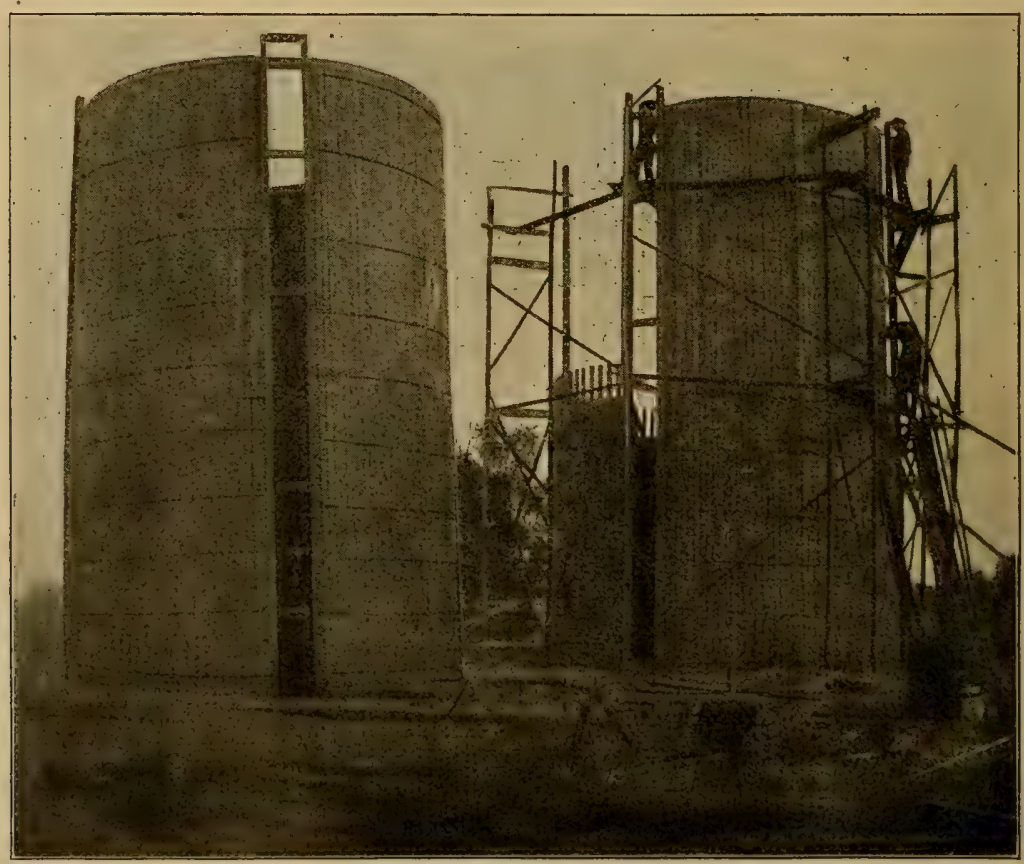

Flgure 13. Two "Buff Jersey" silos in process of building. Note the way the $2 x 4$ 's aro made to break joints.

(Cut loaned by "Buff Jersey," Monmouth, Ill.)

Keep this up around the silo, make sure to alternate the I2-foot and the I6-foot stave, so as to break joints above. Figure I3 shows a silo in course of construction. When all staves are in place screw up the 
nuts snug against the posts. This makes a very durable silo, and one that will not shell to pieces when empty and dry.

All this work is, of course, far easier said than done, but can be done by any handy farmer who wills to do it.

Doors.-On the side most convenient for feeding nail two strips across five of the staves and saw ont these five some 30 inches long, saw on the bevel, as shown in figure I4, making the door longest on the inside. It would be well to have marked out these places when first
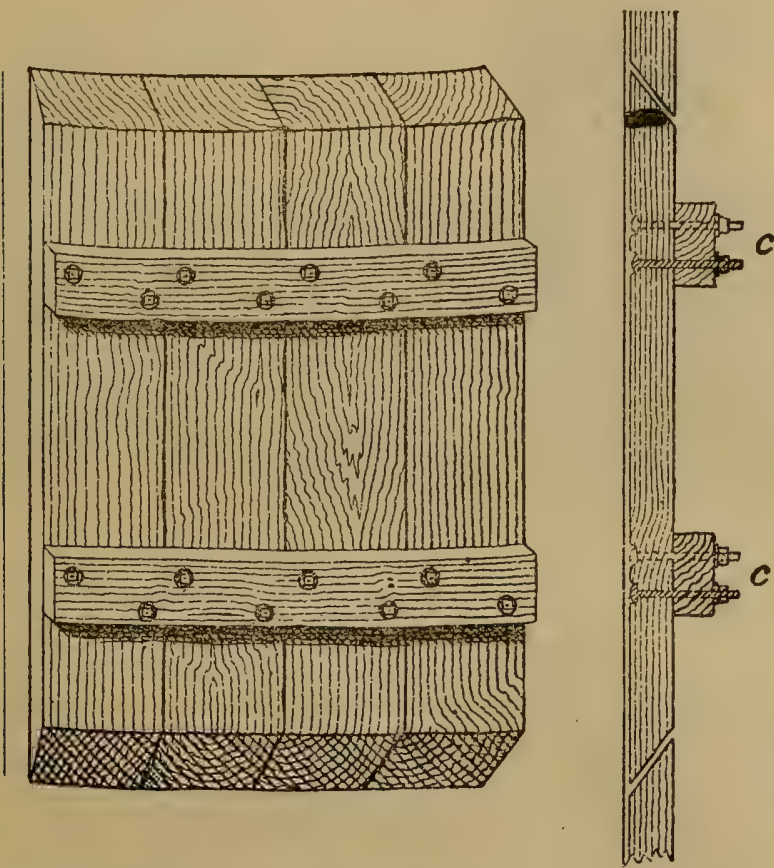

Figure 14. Cut showing way to saw four or five of the $2 \times 4$ 's from a home-made stave silo to make doors. Note the bevel in the sawing, the door " $\mathrm{C} C$ " is the largest on the inside.

putting staves up, so avoid sawing into any spikes. Jambs can then be finally nailed on outside of silo and the surface of contact made tight with felt strips. The doors (four would be sufficient) should be numbered, and each carefully kept for its own opening. Two other $4 \times 6$ pieces, one placed on either side of the doorway to strengthen that part of the silo, would be of value. Bore holes straight through these to allow for the passage of the hoops.

Mr. McNish of Brookfield, Mo.; has two of this kind, of which he says: "One is 16 by 24 and cost me $\$ 80$, and the other is 12 by 26 and cost me \$60." 
Mr. Wm. Plummer, Hale, Mo., has two of these "Buff Jersey" silos and is well pleased with them. One is 16 by 34 and the other is 20 by 34. See figure 20.

Mr. John Miles, Grays Summit, Mo., has one 20 by 30 , and is pleased with it. See figure I5.

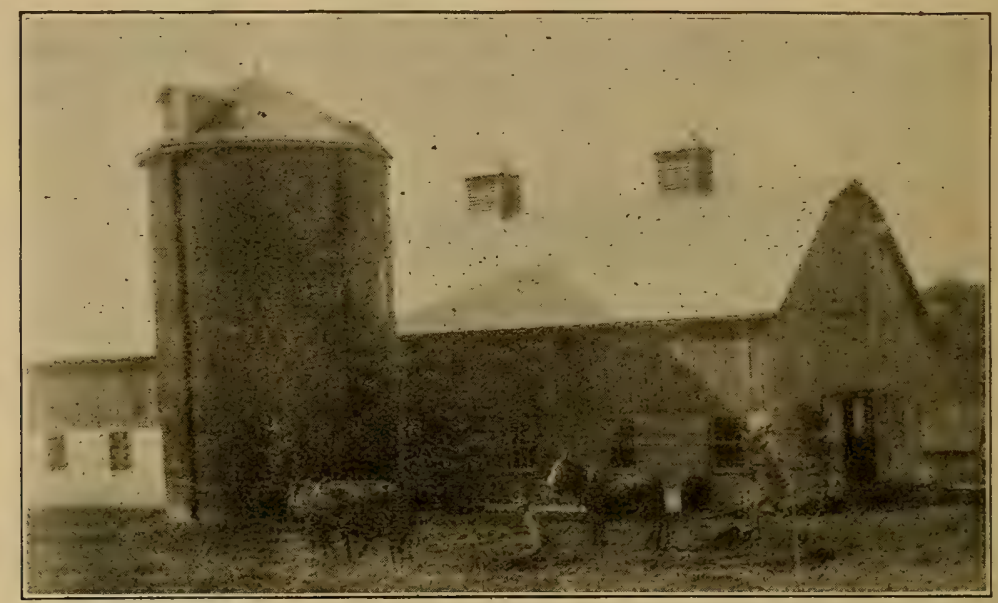

Figure 15. Silo and barn on the farm of J. A. Miles, Gray's Summit, Mo.

(Courtesy Rural World.)

WHAT TO GROW FOR THE SILO.

Corn.-For a silage crop corn comes first. It is by all means the most important. It yields heavily and is relished by all farm animals. Some experienced men prefer to plant thickly and not count on getting ears, but the majority of the best men seem to prefer to plant the silo corn the same as the field corn that is intended to mature grain. Plant as large a variety as will mature before frost in your locality, then let it get almost ripe. It should be cut when the grain is in the dry dough stage, or just beginning to glaze or dent. Corn silage properly made is fully as digestible as the dry fodder, and far more palatable. About the only objection that could be raised to corn is the fact that this plant is fattening in its tendencies and not a muscle and milk producing food, or in other words, its nutritive ratio is wide, it being I to I4.4, $i . c$. I part of protein to 44.4 parts of carbohydrates and fat. To correct this tendency, cow peas, soy beans and velvet beans are coming into favor.

Cow peas are grown and put into the silo along with the corn. Cow peas green have a nutritive value of $\mathrm{I}$ to 4.7 , hence, by putting these into the silo with corn the ratio may be brought down to $I$ to $S$ or 9 , which is about right for feeding steers and nearly low enough for dairy cows. 
To test this point, Prof. C. G. Williams of Ohio divided his herd into two groups, feeding to one group silage composed of corn, cow peas and soy beans, mixed hay and four pounds of grain, and to the other group corn stover, mixed hay and 13.5 pounds of grain per day. The actual amount of digestible food was as nearly the same in each as could be wished. The two sections were fed this for an entire winter. Each cow was charged with what she consumed and credited with what she gave. At the end of the four months the following results were found: "The cows fed on the silage ration produced 96.7 pounds of milk and 5.08 pounds of butter fat per roo pounds of dry matter. The cows fed the grain ration produced 8I.3 pounds of milk and 3.9 pounds of butter fat per Ioo pounds of dry matter. The cost of feed per Ioo pounds of

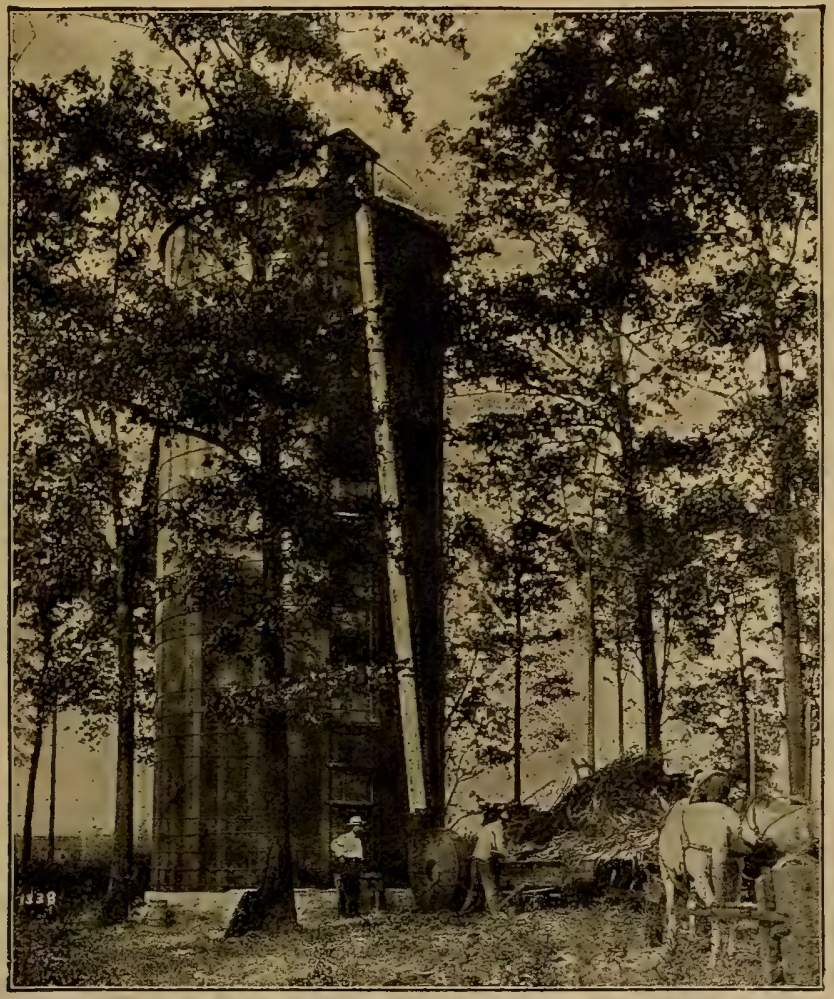

Figure 16. Filling 260-ton stave silo at World's Fair, St. Louis, Mo. This silo is 40 feet high and was filled with blower elevator. Mr. C. T. Graves, Maitland, Mo., Superintendent Jersey Cattle, stands near the silo.

(Courtesy Silver Mfg. Co.)

milk was $\$ 0.687$ with the silage ration, and $\$ 1.055$ with the grain ration. The cost of feed per pound of butter fat was 3.I cents with the silage ration and 22.I cents with the grain ration. The average net profit per 
cow per month (over cost of feed) was $\$ 5.864$ with the silage ration and $\$ 2.465$ with the grain ration."

The above record is not quite complete for the farmer, however, until the effect of these several crops on the soil is considered. Corn, like other grains, is depleting to the soil, while cow peas and soy beans add about \$10 worth of plant food to each acre each season. They can be sown in drills or broadcasted after the wheat is off in June, and be removed in September in time to allow another crop of wheat on the same land if desired. For the good of the soil and for the good of the cows, these two crops, corn and cow peas, should go hand in hand whenever possible.

Soy beans occupy practically the same place as cow peas as fcol for stock.

Clover has been made into silage with good results, but it is not yet a common crop for the silo. Where it can be cured it serves a better purpose as hay.

Alfalfa is also ensiled with good effect in some places. In California some advise putting alfalfa into the silo if it is mixed with foxtail. This seems to disarm the foxtail, but alfalfa, like clover, is more useful as hay.

Sorghum is often made into silage, and is highly rccommended, especially for beef stock and sheep. It is good for the dairy cow, but being so rich in sugar, it would call for a greater expenditure for concentrated protein foods than would corn. Sorghum silage is very fattening and at the same time keeps the system of the animal in excellent condition.

Sunflorecr silage has been recommended, and doubtless would be fine if the stock would eat it more readily. Some cows refuse it altogether.

Grasses have been preserved in the silo, but there is little reason for this practice, because most grasses cure so readily as hay.

Beet tops and pulp in regions of the sugar beet industry are becoming popular as silage. This is especially the case in Europe.

Hash. The silo is sometime used as "catch-all" for left-overs. In the castern states, where feed is high in price and strict economy essential, any Canada field peas and oats left over from the early feeding, later, crimson clover, rye, cow peas and corn, find their way into this preserver. All manner of odds and ends may be made into good food. Alvord once said that "a mixture of equal parts of ragweed, swamp grass or swale hay, old corn stalks or straw and second crop green clover, nearly three-fourths of which would otherwise be almost useless, will mate a superior silage, surprising to those who have never tried it." The same 
author gives the following as the contents of one New York silo: Ist, 18 inches deep of green oats; 2nd, 6 inches of red clover; $3^{\text {rd, }} 6$ inches of Canada field peas; 4th, 3 inches of brewers' grains; 5 th, 2 feet of whole corn plants sowed broadcast, and more ragweed than corn; 6 th, 5 inches of second crop grass; 7 th, 5 inches of sorghum; 8th, a lot of immature corn cut in short lengths. The silage came out pretty acid, but good forage, all eaten up clean."

The writer has put small quantities of common straw and salt hay (coarse hay from the tide meadows along the sea coast) into the silo along with the corn, and seen the cows in winter eat it all as though it were green grass.

\section{FILLING THE SILO.}

When to Cut the Corn.-When the corn has reached the threefourths ripe stage, the stalks still green and the bottom leaves are drying, it should be cut and put directly into the silo. If the corn is not at all mature and is very watery the silage will most likely be very acid, while if the corn goes in dry it will mould, or "fire-fang:" so that it will be greatly or wholly damaged.

Adding Water to Dry Corn.-If the corn, for any reason, has become dry while standing or in the shock, it may still be made into good silage by wetting it thoroughly when it is put into the silo. A half barrel of water to the load of corn will not be too much if the corn is quite dry.

Last fall, at the Missouri Experiment Station, two silos were filled with corn from the same field and in same condition. Each silo was air tight and the silage was equally well tramped in each. The only differcnce between them was that one, a new one, had no roof. Just after the two were filled it began to rain. The sickness of the professor in charge, the resignation of the farm foreman and a general piling up of work caused the silo to remain open to the rain from September Io, when it was filled to November I5, when cover was provided. The silo is 20 fret in diameter and water tight on sides and bottom. During this periud of time 16.68 inches of rain fell. This silage was then forced to absorb 436.68 cubic feet, or 103.7 barrels of water. The silage was only 25 feet deep in the silo. There were then 7,854 cubic feet of silage to absorb $3,266.5$ gallons of water, or one and two-third quarts of water per cubic foot of silage.

This water fell soon after the silage was put in, scarcely any falling in November. This silage came out better by considerable than that from the silo which had a roof. Some farmers make a practice of letting the corn dry in the field 3 or 4 days before hauling in to make lighter work, and then wet the silage well while it is being put into the silo.

Mr. Jones of Roanoke, Mo, has no roof on his silo, which was filled 
in September and caught the rain all winter. His silage is very good. He says the only use there is for a roof is to keep the snow out while it is being fed from; rain cannot harm it.

Mr. H. B. Gurler of DeKalb, Ill., has one silo in the pasture which he has used for eight years without any roof. It is 37 feet in diameter.

The average rainfall in this part of Illinois is 36 inches, yet the silage from this silo is as good as that from his other five silos that have roofs. The water benefits by forcing the air out and packing the contents, and thus preventing decay of the silage.

For best results, cut the corn when it is pretty well matured, even to the point of beginning to dry, then add a lot of water while filling. When in doubt whether to use water, use it; there seems to be no danger of getting too much water.

Tramping the Silage.-Even much tramping by heavy men will not do any particular good except around close to the wall, where it should be walked on well. The surface of the silage while being filled should be concave, low in the center and high about the sides. This done, the silage will not settle away from the walls. It is just the reverse process to stacking hay. Keep the corn chunks well mixed with the lighter stuff, so that at feeding time the animals fed will receive a uniform ration.

Necessary Machinery.-The silage cutter with carrier or blower to elevate the cut corn to the silo and an engine to run it are needed. It does not pay to "fiddle" around with a small cutter. Get one with knives I 4 to 18 inches long, then provide power to make it go. Those who have used both carrier and blower to elevate the cut corn prefer the blower, it generally saves stopping to fix the carrier. The blower will not clog if the cutter is placed close to the silo, so that the wind is almost directly under the stuff carried. The following approximate figures may be of value:

\begin{tabular}{|c|c|c|c|c|c|}
\hline No. of knives. & $\begin{array}{l}\text { Length of } \\
\text { knives, inches. }\end{array}$ & Cost. & $\begin{array}{l}\text { Weighit, } \\
\text { lbs. }\end{array}$ & $\begin{array}{l}\text { Capacity per } \\
\text { hour, tons. }\end{array}$ & $\begin{array}{l}\text { Horsepower } \\
\text { needed. }\end{array}$ \\
\hline 2. & 11 & $\$ 10$ & 440 & 34 & $2-3$ \\
\hline $4 \ldots \ldots$. & 13 & 65 & 560 & $4-6$ & $3-4$ \\
\hline $4 \ldots \ldots \ldots \ldots$ & 16 & 90 & 620 & $5-10$ & $4-6$ \\
\hline $4 \ldots \ldots \ldots \ldots$ & 18 & 120 & 700 & $9-12$ & $6-8$ \\
\hline
\end{tabular}

WITH SELF-FEEDER ATTAOHMENT.

\begin{tabular}{|c|c|c|c|c|c|}
\hline $4 \ldots \ldots \ldots \ldots \ldots \ldots$ & 13 & 95 & 775 & $8-12$ & $5-6$ \\
\hline 4... & 16 & 120 & 835 & $12-15$ & $7-8$ \\
\hline $4 \ldots \ldots \ldots \ldots \ldots \ldots \ldots \ldots \ldots$ & 18 & 155 & 875 & $14-20$ & $7-10$ \\
\hline $4, \ldots \ldots \ldots \ldots \ldots \ldots \ldots \ldots \ldots$ & 19 & $: 00$ & 1100 & $\Sigma 0-25$ & $10-12$ \\
\hline $4 \ldots \ldots \ldots \ldots \ldots$ & 20 & 250 & 1600 & $20-27$ & $10-12$ \\
\hline 4........... & 24 & 300 & 1700 & $25-30$ & $12-15$ \\
\hline
\end{tabular}


The catalog prices named above do not include the carrier or blower, which come extra at about $\$ 2$ per foot for carrier and \$1 per foot for blower. The cutter for blower will cost a little more than for carrier. The price will also vary with the make of machine. The prices are also reduced by a per cent discount, which varies somewhat with the different firms. When you decide to buy select the size that will best suit your needs and correspond with a few reliable dealers. The discount is often surprising. Occasionally one outfit is purchased by a neighborhood and used for filling a dozen or more silos, and occasionally a rig is owned and worked from place to place, the same as a threshing machine, charging so much per ton or per day, but when the silo is to be filled largely by help on the place, or is to be filled at different times as a catch-all, it is far more satisfactory to establish the cutter, house it in, and keep it always ready for use. The horse-power named was steam power; if a gasoline engine is used, increase the rated power about one-third.

Necessary Help.-When the cutter is running it is poor economy to allow it to run empty a part of the time. Better hire more help and keep the thing doing business all the time it is on expense. To keep it running 8 or ro men will be needed, placed as follows: one engineer, one feeder, one in silo, one in field with team cutting corn, and four to six men, each with a team, to draw corn to the machine. To save useless labor the wagons should be low, a low truck with platform, or better, a suspended flat bed between the fore and rear wheels. This saves a large amount of useless lifting of heavy corn. See figure I7.

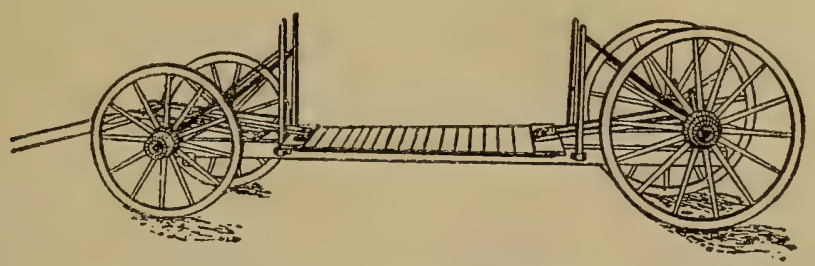

Figure 17. Low down wagon for hauling green corn.

Cost of Filling.-King, of the Wisconsin Experiment Station, studied this problem on a number of farms in Wisconsin and found that on an average it cost 58.6 cents to put one ton of green corn into the silo. Glover of Illinois studied the question in Illinois at a later date, when more improved machinery was being used, and found that the modern machinery enables a man now to do much more than he could Io or I5 years ago. According to his figures, it would cost 40 cents a ton. It is usually considered that 50 cents a ton will cover the cost of filling. Many men, who have had experience in both methods, claim that it is just as cheap, and more satisfactory to make silage, as it is to cut, shock, husk and grind the corn for the cows. 


\section{A SETTLED THING.}

Agricultural College, N. D., Oct. 6, I903:

Gentlemen-I have used one of your *** ensilage cutters for several seasons and am well pleased with the grade of work it does. The No. 19 * ** self-feed ensilage cutters with blower elevator purchased this season for use at the Agricultural College, has done its work satisfactorily.

I was doubtful at first about the blower attachment elevating the green fodder 30 feet high into the silo. I find, however, that the only trouble was to stop the ensilage when it reached the top, for when we first started, it shot across and broke the dormer window on the opposite side, 24 feet away.

The ensilage cutter we used here before had an ordinary chain elevator. Our silo at that time was only 20 feet high, but we had a great deal of trouble with the elevator. We were constantly having to stop to repair or adjust it, but with your machine the only trouble is to get the green corn to it fast enough. ****

Yours respectfully,

J. H. SHEPperd, Dean and Vice Director.

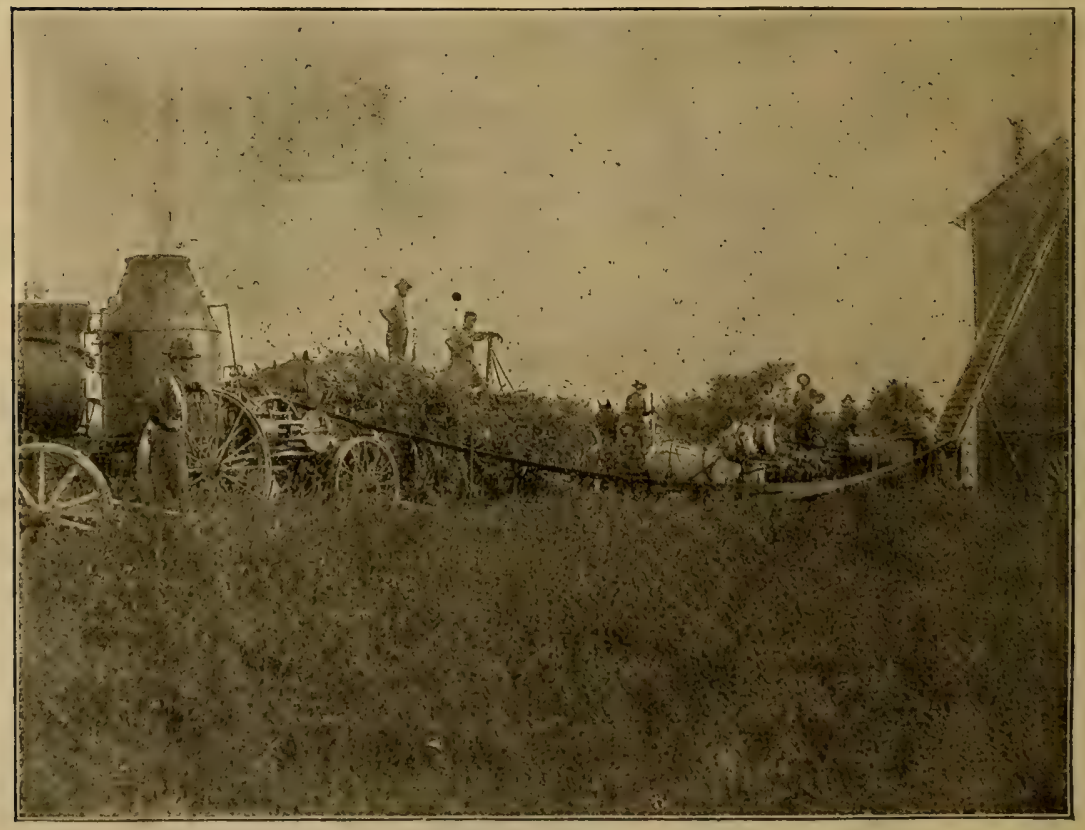

Figure 18. Thls is the rig that filled 20 silos in one season. 


\section{RATE OF WORK.}

*** Edinboro, Eric Co., Pa., Mar. 8, I904.

Dear Sirs-I send you a photograph of my No. 20, special self-feed ensilage cutter, with 45 -foot swivel carrier, which has given me and my customers the best of satisfaction. This machine was driven with a

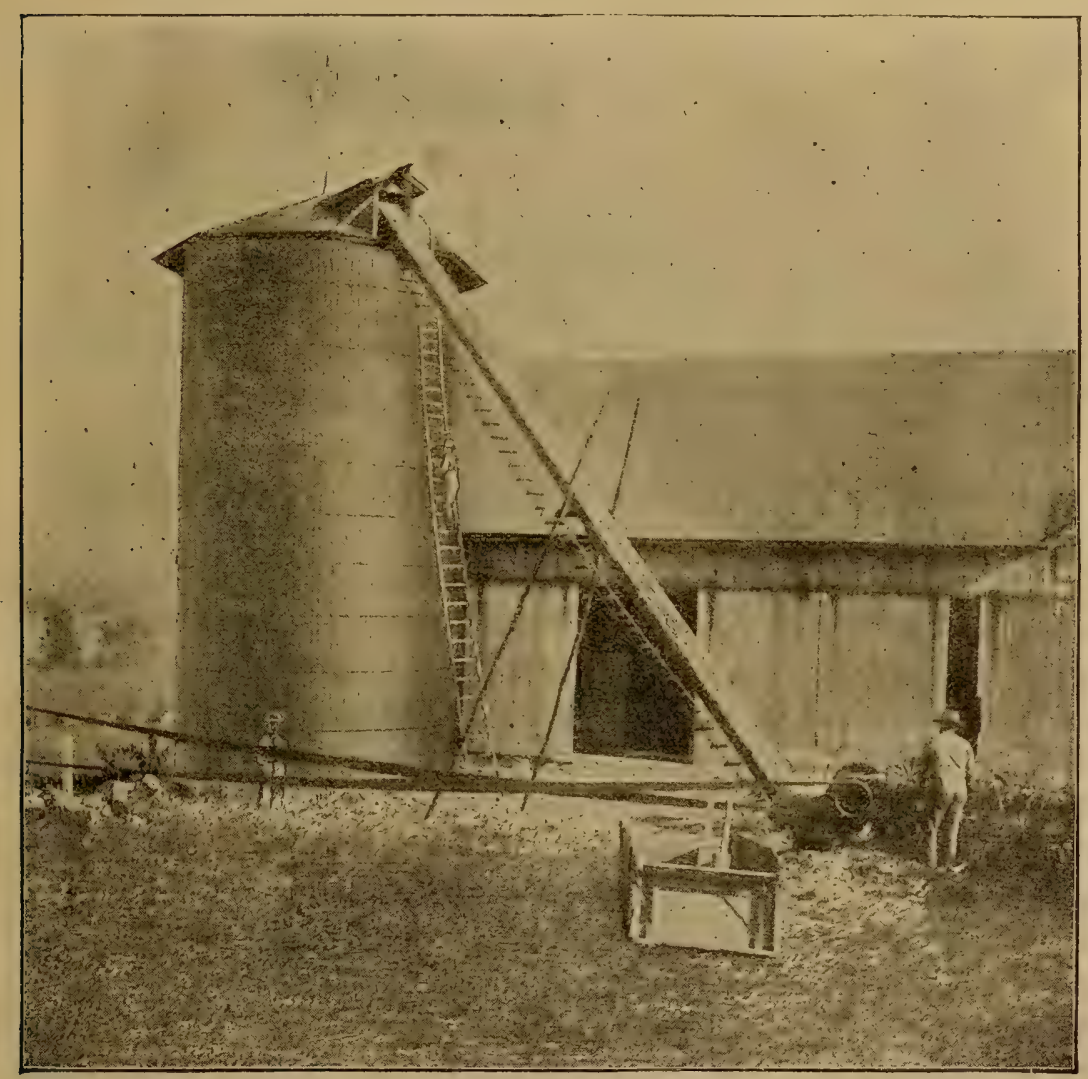

Figure 19. Filling silo with swivel carrier cutter.

I2-horse-power Westinghouse engine, which furnished plenty of power, and at time picture was taken we were cutting 20 tons an hour, or as fast as corn could be got to the machine. There were five teams hauling and 14 men working besides our crew of men and the corn was close by. $* * * *$ We filled 20 silos this season and were always ready for business. $* * * *$

Yours very truly,

A. B. Austin. 


\section{SELF-FEEDER.}

$* * * *$

Salem, Ohio, June Io, Igo3.

Gentlemen-The No. I6 *** self-feed ensilage cutter and swivel carrier we have been using the past three seasons, with which to fill seven large silos, has proven entirely satisfactory and fulfills the guarantee. We usually have four teams to haul the corn in from the field, and have never yet been able to keep the machine continuously supplied. The self-feed saves two men at the cutter and adds materially to its capacity. Very respectfully,

O. E. WHINNERY, Dairyman.

SOMETHING DOING.

Three 550-ton silos and one 1,500 -ton silo readily filled with two No. I9**** cutters and blowers.

$* * *$ Mfg. Co. ***

Washington Courthouse, Ohio, Fëb. 2, I903.

Dear Sirs-During the year rgoI we used one of your No. I9 ensilage cutters, with blower attachment, and found the same to be eminently satisfactory. The machine is capable of doing all that you claim for it, and upon actual tests we were able, at times, to put into a silo, 42 feet high, corn ensilage at the rate of 30 tons per hour, using a I6-horse-power engine.

It was entirely practical to cut at the rate of 12 to 20 tons per hour during the whole day's time. During the year we had three 550ton silos to fill and were under the necessity of getting a cutter which would do the work rapidly in order to get them filled in time. During the past year we filled, in addition to the silos mentioned, a large silo of 1,500 tons capacity, which is 52 feet in height. We filled all of these silos with two of your No. 19 cutters.

Yours truly,

Humphrey Jones.

\section{A CAUTION.}

It would not be right to close this subject without mentioning one feature which is often neglected in a discussion of the merits of the silo. When green feeds are piled up they always begin to heat. This rotting process, which causes the heat, at the same time causes large quantities of carbonic acid gas to be given off. If the silo has been 
filled quickly it will settle several feet and while doing so generates this gas. If all doors inside of silos were closed when it was first filled and the silage settled down to, say $S$ or to feet below any opening, this apparently empty bin will be filled with gas. It is heavier than air and will flow out if it has a chance; give it the chance before sending any one in there to work. Rumning in fresh material will soon stir this gas up with the air and make it safe.

There is just enough danger here to make it wise to notice the conditions in the morning when starting up.

\section{THIE FEEDING OF SILAGE.}

To Dairy Corus.-Cows unaccustomed to silage will become very fond of it in two or three days. They then eat of it as greedily as of green fodder. They eat more of it than they would of dry feed, and, therefore, have more food in their systems with which to make milk after they have subtracted their regular allowance for support. Then, too, food that is relished will be more thoroughly digested than that eaten with repugnance. The bowels of the silage-fed cow are as loose as though on blue grass pasture. This insures health and easy delivery of calves, and lastly, they will, according to Professor Williams' test, give more milk and butter fat per unit of food eaten than those that get only dry food.

The quality of the milk will not be injured in the least, even when the cows are fed heavily, 35 to 40 pounds per day, if the silage be fed after milking instead of just before, and if no silage is allowed to remain in the manger, under the cow, or in a heap in the passages to ferment. Feed only as much as the cow will eat up clean, 30 to 40 pounds per day, and keep the alleys clean. It is the abuse of silage, not its use, that has brought it into disfavor in some quarters. $\mathrm{Mr} . \mathrm{H}$. B. Gurler, who produces exceptionally fine milk for infant feeding in Chicago, uses silage freely, but not carelessly. The writer has had 8 years' experience with silage-fed corvs and their milk and has not had any trouble with bad odor or acid in the milk or butter from it.

To Bulls.-By some it is still considered doubtful whether a full feed of silage is good for breeding bulls, claiming that it has a tendency to make them heavy, slow and uncertain. The writer once fed a mature Holstein bull a ration of 40 to 50 pounds of corn silage a day for a period of six months with excellent results. He got over a hundred robust calves that year, and was exceedingly active and sure. $\mathrm{He}$ received a little grain, but only 2 to 3 pounds of hay a day.

Mr. William Plummer, Hale, Carroll county, Mo., feeds silage to 
dairy cows and calves and says: "Our cows milk fine all winter and come out in good order in the spring. I couldn't get along without my silo now."

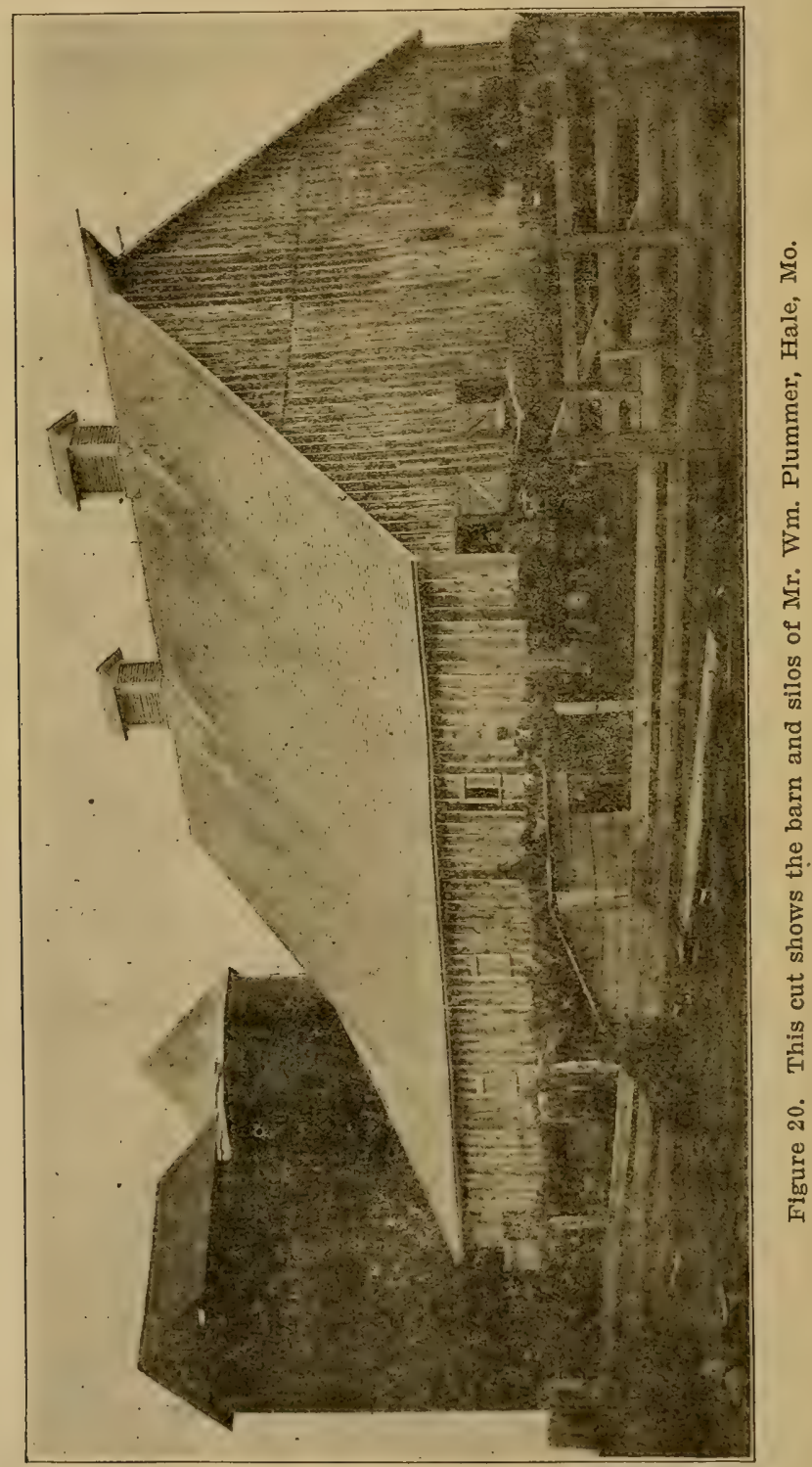

Mr. H. C. Goodrich, Calhoun, Henry county, Mo., says: "No dairyman can afford to be without a silo. I consider it the best and cheapest way to save the whole corn crop. I have fed ensilage to dairy cows for 12 or I 3 years." 
Mr. Jas. Elliot, Windsor, Henry county, Mo., feeds silage to cows and young stock and says: "I like ensilage for feeding very well. Woud not like to be without one. It is not only good feed for cows but all kinds of cattle, and when it is put up in the fall it is so much easier to get at than to have to go to the fields for corn fodder; with ensilage we get the whole corn plant for food."

Mr. Fred Parcher, Maryville, Nodaway county, Mo., feeds silage to cows and young cattle and says: "Results in a saving of one-half in feed store bills and over one-half in amount of hay eaten."

Mr. H. S. Hand, Appleton City, St. Clair county, Mo., says: "[ find it (silage) excellent for dairy cows. Our cows milk as well in winter as they do in summer; in fact, they usually gain when we commence to feed."

Mr. John Miles, Gray's Summit, Franklin county, Mo., feeds silage to dairy cows and horses and says: "Results are good. I like it well and think it an ideal method of securing succulent food."

Mr. Fritz Sensor, Corder, Lafayette county, Mo., says: "I have been feeding it to all of my cattle. It is of most value for milk cows."

Mr. John Patterson, Kirksville, Adair county, Mo., has fed silage for many years and says of it: "When I speak of the economy of putting corn into silos to feed cows I don't mean that it is good for cows only-it is good for all kinds of stock. All seem to like it and thrive on it, and when you get buildings and machinery for it, it does not cost any more to put it in silos than to cut and shock, etc., and it is much more convenient to feed in barns or sheds where stock can be comfortable and all the manure can be saved."

Mr. N. H. Gentry, Sedalia, Mo., says: "I put up a silo in the past summer 30 feet high by 20 in diameter. We filled it with cut corn and it is proving a very cheap, economical feed. We are feeding it to all our cattle, and our work horses have had no other grain all winter, keeping in good condition. In thus consuming the whole corn plant it proves a very cheap feed. We mix a little other grain with it in feeding milk cows and young cattle we wish to push along, but the dry cows get nothing but it, and they eat very little hay. I think I will put up a smaller silo for summer feeding in case of severe drouth, and after carrying it through the summer and it is not needed, we can feed it out during the winter or fall."

Mr. H. B. Gurler, who produces certified milk from I5O cows, some of which milk was sent to Paris, France, and was still sweet at the end of 21 days, though no preservative but cleanliness and cold were used, says of the silage: "I have been using silage for 25 years. I was enthusiastic from the first. I never went crazy over it, but my 
confidence has been increasing from year to year, and I never was so firmly fixed in the opinion that it is a necessity on the farm as I am now. There is no better feed for producing perfectly sweet milk than silage fed properly."

Mr. C. T. Graves, Maitland, Mo., had charge of the Jerseys at the World's Fair in 1904, and the excellent showing made there was partly due to the superior corn silage that was fed.

Redmond \& Hurst, Tipton, Moniteau county, Mo., uses two "bin" silos and says: "We are milking 50 cows in all stages of lactation, Io of which are heifers with first calf, and our check for January cream was $\$ 265.00$; not so bad for winter.

Cows giving milk should be fed from 30 to 40 pounds of silage a day, half in the morning and half at night, or as much as they will eat up clean every time. If a little is left in the manger take it out before it spoils-and next time feed a little less. After the silage is cleaned up give as much alfalfa, clover or cow pea hay as the animal will clean up readily. Mix the grain I part cottonseed meal to 6 parts corn and cob meal; or I part oil meal to 5 parts corn and cob meal; or I part bran to 3 parts corn and cob meal. Then give of this mixture one pound for every three pounds of milk the cow is giving per day. If the cow gives 6 pounds ( 3 quarts) of milk a day, feed 2 pounds of grain; if 30 pounds ( 15 quarts), give to pounds grain, etc. Oats may be substituted for the bran, or gluten meal for the oil meal. This will give as nearly a balanced ration as need be attempted.

To Beef Stock.-Corn or sorghum silage fed to beef cattle keeps then in tone and enables them to make better use of other food consumed. From 30 to 40 pounds per day will not be too much when once they are gotten onto full feed. Several of our experiment stations, after careful trials, recommend it highly.

In the summary of Bulletin 73, Illinois Experiment Station, is found: "It requires a third longer to feed an acre of corn silage than an acre of shock corn. *** The silage-fed steers were in much better thrift and flesh at the end of the experiment ( 88 days) than were the shock-fed steers. *** It should be noted that the silage-fed lot consumed less feed than the shock-corn lot and less feed per pound of gain. The amount of dry matter required to produce a pound of gain of meat, when the corn was fed in the form of silage, was 6.52 pounds; where fed in the form of shock corn it was 8.57 pounds."

Mr. J. M. Doughty, herdsman, Missouri Experiment Station, says: "The Experiment Station beef-breeding herd is being kept through the winter on silage and alfalfa without grain. Mature cows receive 25 to 
30 pounds of silage at night and a feed of hay in the morning. A few of the cows did not take to the silage at first, but they all learned to relish it and they never leave any silage, although a little hay is left occasionally. I believe that if farmers only knew the value of silage for feeding cows and maintaining steers silos would soon become numerous."

Mr. McNish of Brookfield, Mo.," has two silos. He says: "I feed all classes of cattle with good results, especially for growing stock. I fed a car load of steers silage and ear corn and topped the market. The only difficulty in feeding the silage with ear corn is that the cattle which are to be fattened will quit eating the ear corn and eat the silage alone. Corn, I believe, should be ground when feeding with silage for fattening steers."

Mr. H. S. Hand, Appleton City, Mo., says: "I feed all kinds of stock on silage with good results. I have used it for stall feeding with

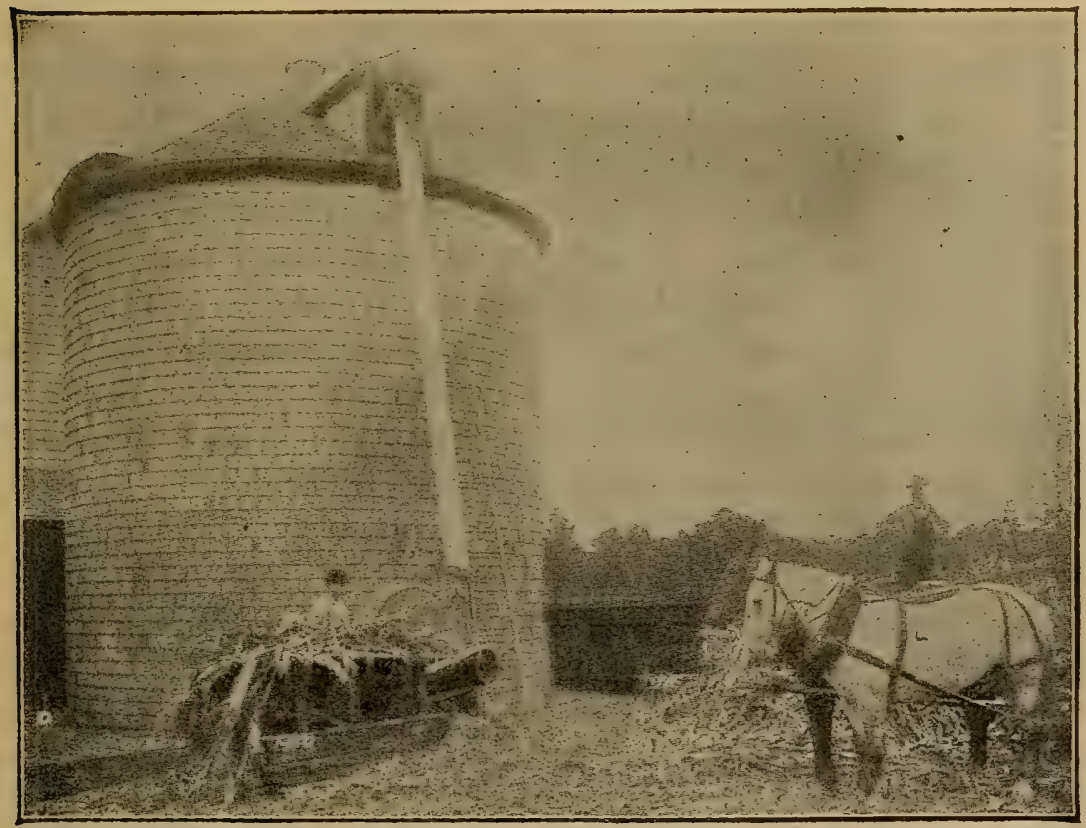

Figure 22. A round-shingled silo being filled with a blower cutter.

(Courtesy Silver Mfg. Co., Salem, Ohio.)

ground corn, cob and all. Would not think of wintering stock without silage. We are feeding 300 head of cattle and find the silo a great saver of feed."

"Humphrey Jones of Washington Court House, Ohio, constructed 
three silos in Igor, which he made 26 feet in diameter and 36 feet high, holding each from 500 to 600 tons. In 1902 he built another, 39 feet wide and 52 feet high, of cement. Mr. Jones has found great advantage in feeding silage to cattle. His silage consists of three-quarters corn and one-quarter soy beans, cut in the fullest maturity. Some of the advantages, as outlined by him, are a greater feeding value of corn than when fed dry, making gains cheaper; getting cattle to feed better; finishing up cattle better and more evenly on market, and its adaptability to stock cattle. Corn that will make 50 bushels per acre will yield 8 tons of silage, which he values at $\$ 2.50$ a ton. He regards a feed of about 5 pounds of silage and one-third of a pound of hay for each hundred pounds live weight a satisfactory feed. A steer will hardly consume over 50 pounds of silage a day, if either I,O0O or I,300 pounds weight. Mr. Jones feeds, he assumes, about I pound of grain in his silage to a hundred pounds of live weight, and he also gives about onchalf pound of cottonseed meal with the silage per hundred pounds of live weight. Cattle rarely eat over 4 pounds of hay per day when fed silage freely. The daily cost of feed for a silage-fed steer was given at II cents, while one corn-shock-fed will cost 20 cents. No discrimination occurred against silage-fed animals on the market."

To Horses.-If the horses can be taught to relish silage, it will be very good for them in small quantities, say from 10 to 20 pounds per day. Some have refused to learn, but most of them will soon learn to like the peculiar pungent odor, especially if aided at first by some of nature's "plain sauce." Some feeders mix one part corn silage and two parts cut straw and let this be the regular diet. A horse fed moderately of silage will have a more glossy coat, looser skin, and in general, greater evidence of thrift than one fed wholly on dry food. Idle horses may receive more than those at work, and heavy horses more than drivers.

To Shecp.-To be wintered through in best form, sheep must have some succulent food, and for this purpose a great many mangels, rutabagas, turnips, etc., were formerly raised, but at present corn or sorghum silage is getting to be looked upon with great favor. Fattening stock respond well to the sugar in sorghum and corn silage, especially when there are nubbins of corn throughout the chopped corn stalks. For cwes in lamb, silage is most excellent. It allows them to drop their lambs in January or February without trouble and increases the milk flow very materially. The lambs are strong and healthy and ready to respond to feed and come onto the early market with profit. From 3 to 4 pounds a day per head is sufficient. Like other farm animals, they require some dry hay every day. This hay would best be alfalfa, 
clover or cow pea, as these feeds contain the protein so essential to economical feeding. Mr. J. M. Turner of Michigan says, "Of late years we have annually put up 3,200 tons of corn ensilage, and this has been the principal ration of all the live stock at Springdale farm, our Shropshire sheep having been maintained on a ration of ensilage night and morning, coupled with a small ration of clover hay in the middle of the day."

To Swine.-As a food for swine there is some conflict of opinion. Some feeders, including the writer, have fed it with very indifferent success, while others make a practice of feeding it and claim that in small quantities it substitutes pasture and keeps the swine in better thrift than when fed slop and grains without the succulent adjunct. Mr. J. W. Pierce of Indiana writes on this subject: "We have fed our sows, about 25 in number, for four winters, equal parts of ensilage and corn meal put into a cooker and brought up to the steaming state. It has proved very beneficial to them. It keeps up the flow of milk of the sows that are nursing the young, equal to when they are running on clover. We find, too, that when the pigs are farrowed they become more robust, and take to nursing much sooner and better than they did in winters when fed on an exclusively dry diet. We also fed it to our sheep. To sixty head we put out about six bushels of ensilage." That a pig should eat silage is no more than we should expect from an animal that feeds on pasture grass as well as hogs do.

To Poultry.-Poultry in winter crave green food. Some poultry farmers provide cabbages, others crushed roots, but there is a strong tendency now to provide a silage made of tender clover and green sweet corn. A poultry man writes as follows in "Orange Judd Farmer:" "Clover and corn ensilage is one of the best winter foods for poultry raisers. Let me tell you how to build four silos for \$I. Buy four coal oil barrels at the drug store, burn them out on the inside, and take the heads out. Go to the clover field when the second crop of the small June clover is in bloom, and cut one-half ton three-eighths of an inch in length, also one-half ton of sweet corn, and run this through the feed cutter. Put into the barrel a layer of clover, then a layer of corn. Having done this, take a common building jack-screw and press the silage down as firmly as possible. Then put on this a very light sprinkling of pulverized charcoal, and keep on putting in clover and corn until you get the barrel as full as will admit the cover being put back. After the four-barrel silos are filled, roll them out beside the barn and cover them with horse manure, allowing them to remain there thirty days. Then put them away, covering with cut straw or hay. When the cold, chilling winds of December come, open one of these 'poultrymen's silos,' 
take about twenty pounds for one hundred hens, add equal parts of potatoes, ground oats and winter rye, place same in a kettle and bring to a boiling state. Feed warm in the morning, and the result will be that you will be able to market seven or eight dozen eggs per day from one hundred hens throughout the winter, when eggs bring good returns." When silage cannot be got, the fine leaves that break off from alfalfa and clover in the handling, when wet with warm water, are a gooul substitute.

As a Summer Convenience.-The silo is not restricted to winter use only. Summer silage feeding is getting to take the place of the soiling system. When land is high in price, cows are often fed in the stable the year round, in summer the green food being brought to them fresh from the fields every day. A larger number of cows can be lept in this way than by pasturing, but with the summer silo a still larger number may be maintained, and that, too, without the annoyance of being compelled to run to the field every day, rain or shine to cut and draw in a jag of green feed.

\section{THE SILO IN THE SOUTH.}

To preserve food for winter feeding in the south is more difficult than in the north. In the north a shock or stack of corn fodder may get snowed under, but remains green and palatable, while in the south, where the winter wetness is in the form of rain, an exposed stack of corn fodder would soon bleach tasteless if not rot outright.

The- silo should be pushed as the winter pasture for the south as well as for the north.

Professor A. M. Soule, formerly of Tennessee, now of Virginia, speaking of silage for the south, says: "It is, however, clearly recognized as one of the most economical and satisfactory food stuffs obtainable. At the Tennessee Experiment Station four beef cattle have been maintained for I 50 days on silage produced on 0.91 acre of land. Every farmer who is interested in the feeding and maintenance of live stock should have a silo."

Mr. C. L. Willoughby, professor of animal husbandry at the Georgia Experiment Station, Experiment, Ga., in reply to a letter on the subject, says: "The silo has been successful in Georgia for twenty years. I imagine the men who entered the dairy business at all in Georgia have been just as modern in the use of such conveniences as any class of men in America. Those who have used a silo say they could not possibly do without them. They are used all over Georgia, and even in the northern part of Florida, just as readily as in Missouri. We have a wide range of climate in this State. The elevated region in northern 
Georgia has a climate very little different from that of the Ozarks, while the climate of south Georgia is almost sub-tropical.

"The most common type now being built is the ordinary wood stave silo with round hoops. Many of the silos built fifteen or twenty years ago were made of thick cement walls, usually square in shape, and some of these are in use yet. Good pine lumber is reasonably cheap here yet, so that a hundred-ton silo seldom costs more than $\$ 75.00$.

"The principal crop used in the silo is corn, with sorghum as a close second. The corn is often mixed half and half with sorghum, and many dairymen grow cow peas or velvet beans with the corn, permitting the vine to climb up the stalk, and then running the vine and stalk together through the cutter. The pea vines or velvet beans do not make good silage alone.

"In a general way, the dairymen of south Georgia are compelled to use up their silage a little faster than you would in Missouri, on account of the warm climate hastening the rotting of the material."

The silo for the south should be made a little narrower for its capacity than those in the north, in order that the silage may be fed down more rapidly. About 6 square feet of silage surface for each cow per lay will be sufficient. For 10 cows and a few young stock a silo should be then ro feet in diameter and deep enough to hold the necessary amount.

A silo Io fect in diameter and 25 feet deep will hold, approximately, 40 tons of silage, which will grow on 3 to 4 acres of ground and furnish fecd for lo cows and 6 to 8 head of young stock fer 120 days.

While remembering its many advantages, yet not forgetting its limitations, the silo should be pushed in all parts of the country. 


\section{ANALYSES OF FEEDING STUFFS.}

Table showing average amounts of digestible nutrients in the more common American fodders, grains and by-products. Compiled by the editors of Hoard's Dairyman, Fort Atkinson, Wis.

Name of feed.

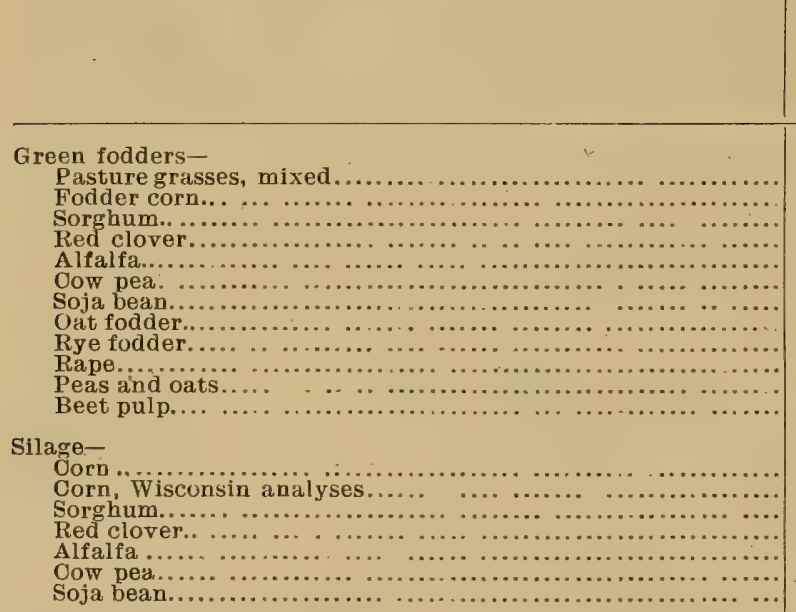

Dry fodder and hay -

Oorn fodder.

Corn fodder, Wisconsin analyses.

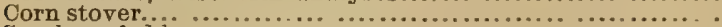

Sorghum fodder.

Red elover.

Alfalfa.

Barley.....

Blue gras

Orab grass.

Johnson

Millet.

Uat hay.....

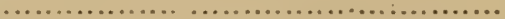

Orchard gras

Prairie grass..

Red top...

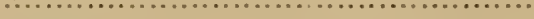

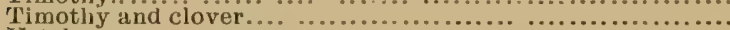

Vetch.

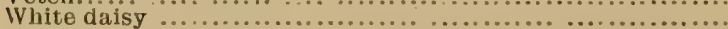

$\exists$ Digestible nutrients in 100 lbs.

raw-

Barley

Oat.....

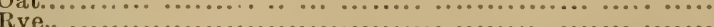

Wheat.

Roots and tubers -

Artichokes......

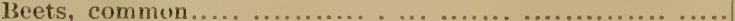

Beets, sugiar. .

Uarrots.

Mangels..

P'arsuips.

Yotatoes..

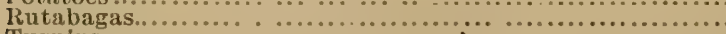

Turnips.

Sweet potatoes.

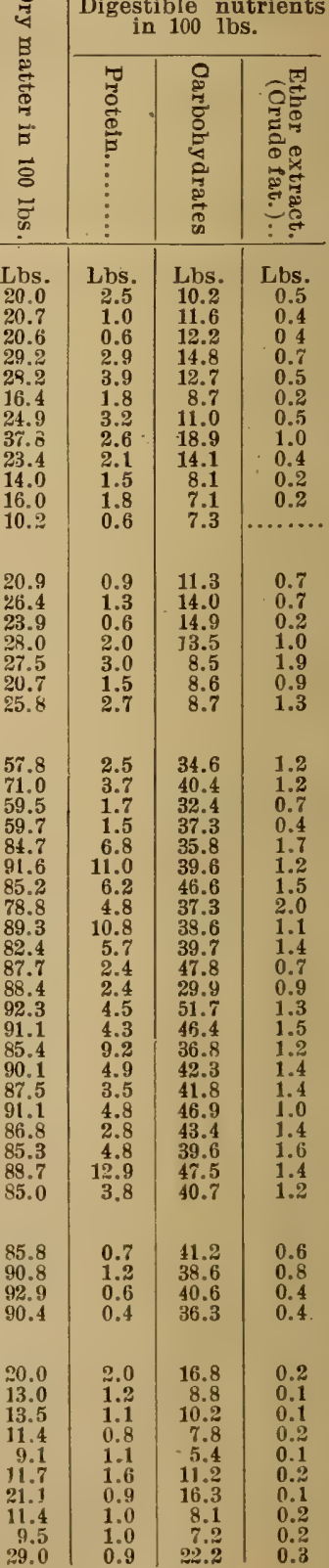


ANALYSES OF FEEDING STUFFS-Oontinued.

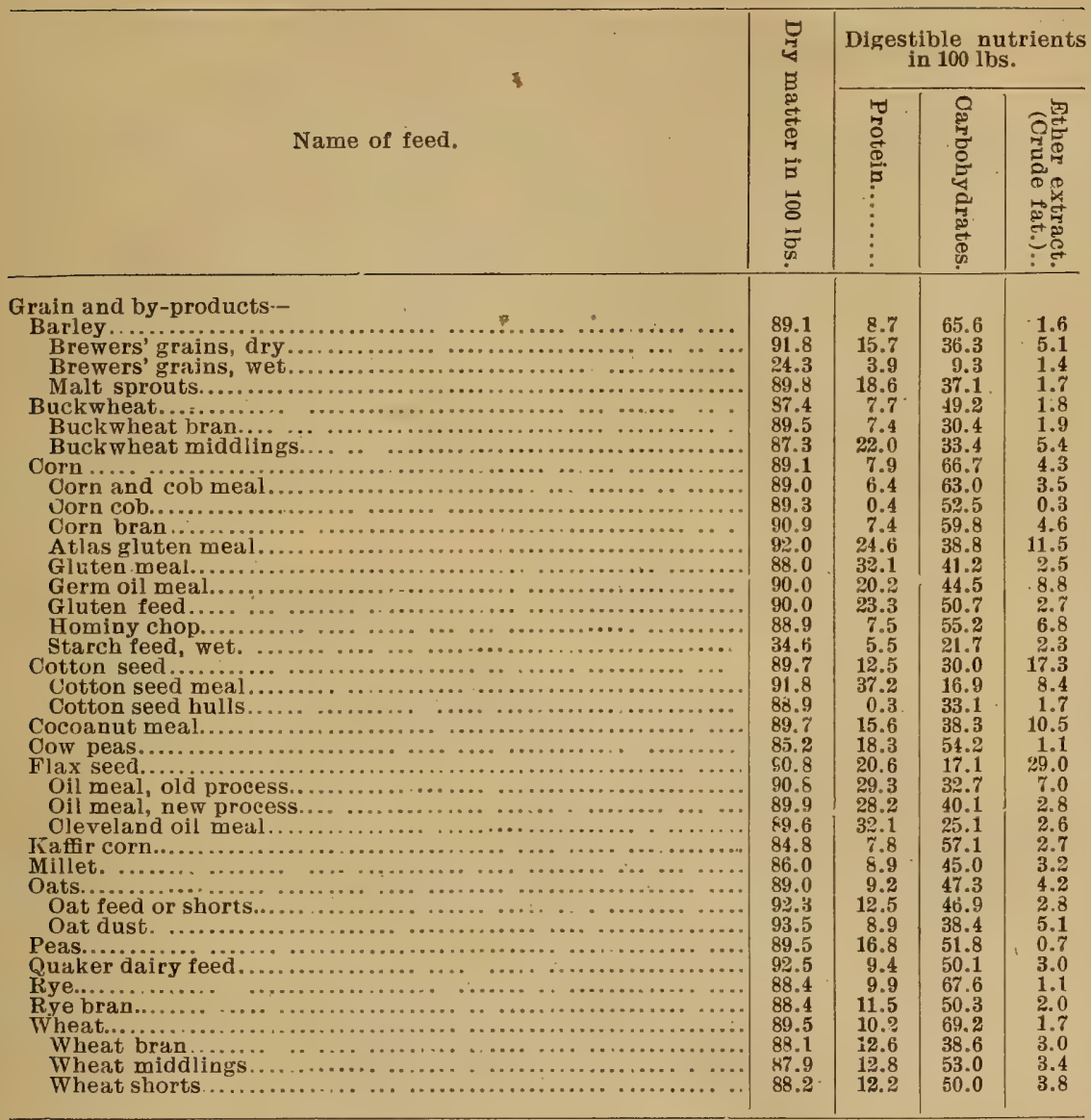

\section{WEIGHT OF CONUENTRATED FEEDS.}

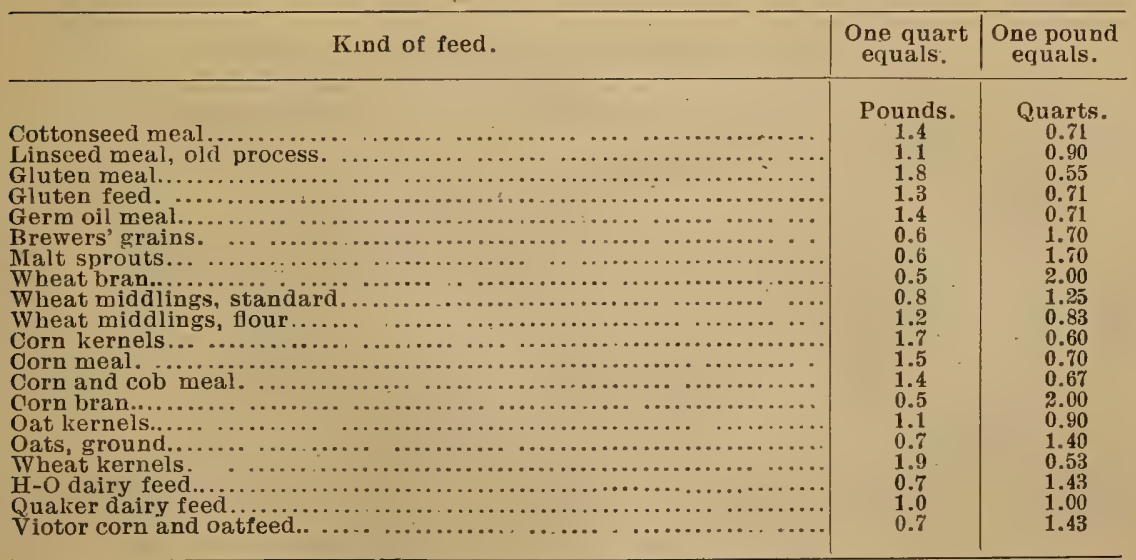




\section{MAKE MORE USE OF OUR EXPERIMENT STATIONS.}

In every state in the Union experiment stations are maintained and men employed to study the problems of the farmer and give to him free the results of these labors. Although much good has been accomplished, still greater service may be rendered when the farmers, as a whole, learn to look to this source for the solution of their problems. One reason that they do not now get more good out of the bulletins is that they do not know where to send nor what definite thing to ask for to get what they want. The following list of bulletins on different phases of farm work, arranged under topical heads for convenience, are all free for the asking:

\section{The Breeds of Dairy Cattle Discussed-}

(The purer the blood of any animal the stronger will be that blood.)

Bulletin No. I06, Dept. Agri., Washington, D. C.

How to Start a Dairy Herd-

("Well begun is half done.")

Bulletin 55, Dept. Agri., Washington, D. C.

Keep the cows you have, feed them well, test them and save seed from the best only.

How to Raise Good Calves on Skim Milk-

(A fall calf raised on skim milk and corn is worth as much at

I year as a spring calf that follows the cow.)

Bulletin No. 57, Mo. Exp. Sta., Columbia, Mo.

Bulletin No. I26, Kan. Exp. Sta., Manhattan, Kans.

\section{How to Feed a Dairy Cow-}

(The farmer can't control the price he is to receive for butter or cream, therefore it is up to him to produce economically if he wishes a profit.)

Bulletin No. 58, Mo. Exp. Sta., Columbia, Mo.

Bulletin No. 155, Ohio Exp. Sta., Wooster, Ohio.

Bulletin No. 67, Minn. Exp. Sta., St. Anthony Park, Minn.

The Farm Cream Separator-

(Is to the dairyman what the twine binder is to the grain raiser.)

Bulletin No. 20I, Dept. Agri., Washington, D. C.

Butter Making on the Farm-

(There is an easy and a hard way to do all work.)

Bulletin No. 24I, Dept. Agri., Washington, D. C. 
Care of Milk on the Farm-

(A delicate food, which is easily spoiled.)

Bulletin No. 63, Dept. Agri., Washington, D. C.

Bulletin No. 74, Dept. Agri, Washington, D. C.

Bulletin No. 203, Cornell College, Ithaca, N. Y.

Silos, and How to Build Them-

(Be taught by your neighbor's success.)

Bulletin, March, I906, State Board of Agriculture, Columbia, Mo.

Bulletin No. 32, Dept. Agri., Washington, D. C.

Bulletin No. IO2, I1l. Exp. Sta., Urbana, Ill.

The Farmer's Creamery in Missouri, When and Hore to Build-

Circular information.No. 18, Exp. Sta., Columbia, Mo.

$V$ alue of the Individual Cores in the Dairy, and How to Find Ont These Values-

(Some cows are ten times more profitable than others.)

Bulletin No. 66, I11. Exp. Sta., Urbana, Ill.

Bulletin No. 28, Storrs Exp. Sta., Storrs, Conn.

Bulletin No. 29, Storrs Exp. Sta., Storrs, Conn.

Bulletin No. 95, S. C. Exp. Sta., Clemson College, S. C.

I aine of Skim Milk for Pig Feeding-

(Corn and skim milk will produce pork 50 per cent more cheaply than corn and blue grass pasture.)

Bulletin, Sept. 1905, State Board Agri., Columbia, Mo.

Practical Suggestions for Farm Buildings-

Bulletin No. I26; Dept. Agri., Washington, D. C.

Cement Mortar and Concrete-

(Preparation and use for farm purposes.)

Bulletin No. 235, Dept. Agri. Washington, D. C. Alfalfa Growing-

(Alfalfa is probably the most profitable crop for the dairymen or stockmen, and it can be grown on many Missouri soils.)

Instructions for Missouri Alfalfa Growers. Circular of Missouri Agrl. Exp. Sta., Columbia, Mo.

Alfalfa on Illinois Soil. Bul. 75, I11. Agr. Exp. Sta., Urbana.

Alfalfa Bulletin 75, Arkansas Agr. Exp. Sta., Fayetteville, Ark.

Corn Improvements-

(Any enterprising farmer can add 25 per cent to the yield of his corn fields by careful attention to seed, soil and cultivation.)

Corn Improvements for Missouri. Bulletin 59, Mo. Agr. Exp. Sta., Columbia, Mo. 
Suggestions for Missouri Corn Growers. Circular I9, Mo. Agr. Exp. Sta., Columbia, Mo.

Corn Improvement. Bulletin 105, Ind. Agr. Exp. Sta., Lafayette, Ind.

\section{Soil Fertility-}

(A system of farming which shall include a systematic rotation of crops and the keeping of farm animals, whose manure shall be returned to the land, must sooner or later be adopted, or our children will be brought to starvation.)

Methods of Maintaining the Productive Capacity of Illinois Soil. Circular 68, Ill. Agr. Exp. Sta., Urbana, Ill.

Nitrogen Bacteria and Legumes. Bulletin 94, Agr. Exp. Sta., Urbana, I11.

Barnyard Manure: Farmer's Bulletin I92, U. S. Dept. of Agr., Washington, D. C.

The Drainage of Farm Lands. Bulletin I87, U. S. Dept. of Agr., Washington, D. C.

Cowpea Experiments. Bulletin 77, Ark. Agr. Exp. Sta., Fayetteville, Ark.

(The cowpea is not half appreciated by Missouri farmers; by the judicious use of this crop for hay, pasture and for plowing under, the land can be greatly increased in fertility, besides securing a profit from the crop.)

Cowpea Experiments. Bulletin 77, Ark. Exp. Sta., Fayetteville, Ark.

Leguminous Plants. Farmer's Bulletin I6, U. S. Dept. of Agri., Washington, D. C.

Cowpeas. Farmer's Bulletin 89, U. S. Dept. of Agr., Washington, D. C.

Cowpea Hay. Bulletin 8o, Ark. Exp. Sta., Fayetteville, Ark.

Some Excellent Books, Which Sell at Reasonable Prices-

"Creamery Patron's Hand Book" (a good book for dairy farmers), published by National Dairy Union r54, Lake St., Chicago, Ill.

"American Dairying," by H. B. Gurler, published by J. H. Sanders Publishing Co., Chicago, Ill.

"A Book on Silage," by F. W. Woll, published by Rand, McNally, Chicago, Ill.

"Soiling Crop and the Silo," by Thos. Shaw, published by Orange Judd Co., New York City. 
"Animal Breeding," by Thos. Shaw, published by Orange Judd Co, New York City.

"Dairy Bacteriology," by H. L. Russell, published by the author, Madison, Wis.

"The Fertility of the Land," by I. P. Roberts, published by the Macmillan Co., New York City.

"Testing Milk," by Farrington \& Woll, published by Mendota Book Co., Madison, Wis.

"The Care of Animals," by N. S. Mayo, published by the Macmillan Co., N. Y.

"The Farmer's Business Hand Book," by I. P. Roberts, published by the Macmillan Co., New York. 


2 

LIBRARY OF CONGRESS

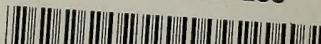

